\title{
Deployment Effects of Marine Renewable Energy Technologies
}

\section{Framework for Identifying Key Environmental Concerns in Marine Renewable Energy Projects}
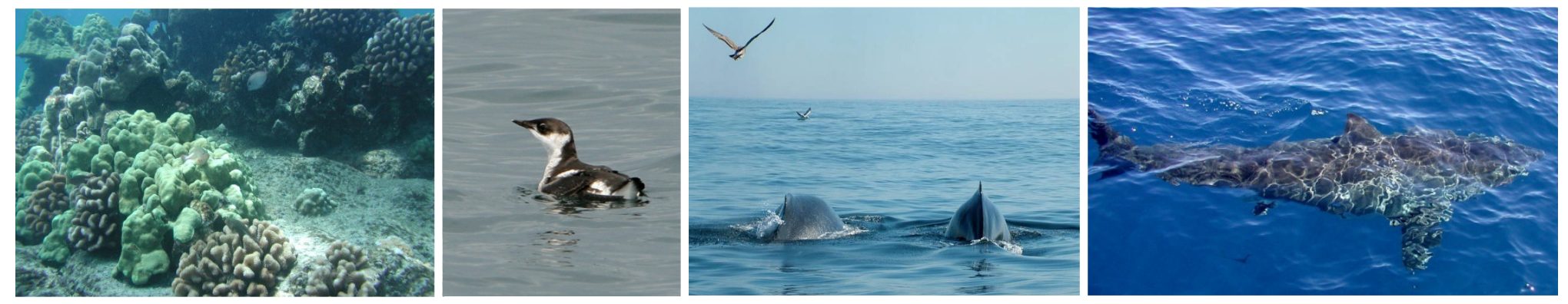

Prepared by RE Vision Consulting, LLC on behalf of the U.S. Department of Energy June 2010

Principal Investigator - Mirko Previsic

In Collaboration with

Authors

Report ID
H. T. Harvey \& Associates

Sharon Kramer, Mirko Previsic, Peter Nelson, Sheri Woo

RE Vision DE - 003

H. T. HARVEY \& ASSOCIATES

ECOLOGICALCONSULTANTS 
United States Department of Energy - Wind \& Water Power Technologies Program Office of Energy Efficiency and Renewable Energy 1000 Independence Ave. S.W. Washington, DC, 20585 Phone: 1-877-337-3463

Document Prepared for DOE by:

RE Vision Consulting, LLC

www.re-vision.net

Project Manager: Mirko Previsic

Email Address: mirko@re-vision.net

Suggested citation: Kramer S, M Previsic, P Nelson, S Woo. 2010. RE Vision DE-003: Deployment effects of marine renewable energy technologies - Framework for identifying key environmental concerns in marine renewable energy projects. U.S. Department of Energy, Advanced Waterpower Program. 


\section{DISCLAIMER OF WARRANTIES AND LIMITATION OF LIABILITIES}

This document was prepared by the organizations named below as an account of work sponsored or cosponsored by the U.S. Department of Energy (DoE). Neither DoE, RE Vision consulting, LLC (RE Vision), any cosponsor, the organization (s) below, nor any person acting on behalf of any of them.

(A) Makes any warranty or representation whatsoever, express or implied, (I) with respect to the use of any information, apparatus, method, process or similar item disclosed in this document, including merchantability and fitness for a particular purpose, or (II) that such use does not infringe on or interfere with privately owned rights, including any party's intellectual property, or (III) that this document is suitable to any particular user's circumstance; or

(B) Assumes responsibility for any damages or other liability whatsoever (including any consequential damages, even if RE Vision or any RE Vision representative has been advised of the possibility of such damages) resulting for your selection or use of this document or any other information, apparatus, method, process or similar item disclosed in this document.

The views and opinions of authors expressed herein do not necessarily state or reflect those of the United States Government or any agency thereof, or RE Vision consulting, LLC. The development of this document was funded by the United States Department of Energy.

Organization(s) that prepared this document:

H. T. Harvey \& Associates

RE Vision Consulting, LLC 


\section{Table of Contents}

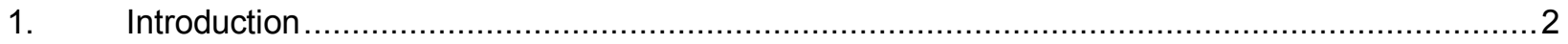

2. Generic Wave and Tidal Energy Development Effects...................................................... 5

2.1 Potentially affected physical attributes and marine organism groups................................... 6

$2.2 \quad$ Generic project actions and their potential effects ........................................................... 7

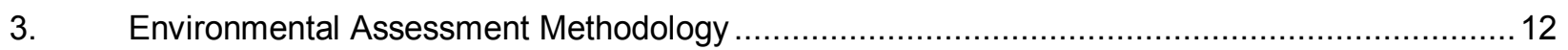

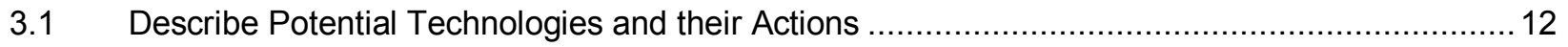

3.2 Describe the Affected Environment of Potential Sites ......................................................... 13

3.3 Criteria for defining the extent of the affected physical environment.................................... 14

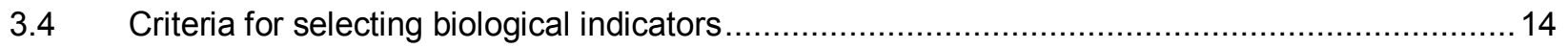

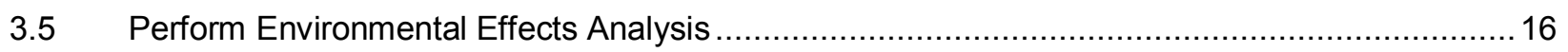

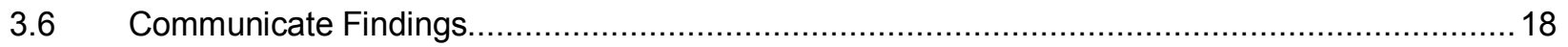

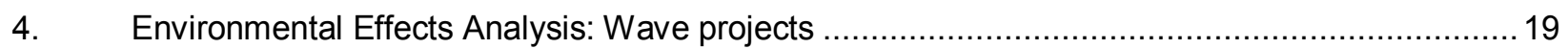

$4.1 \quad$ Summary Description of Wave Energy Technologies.......................................................... 19

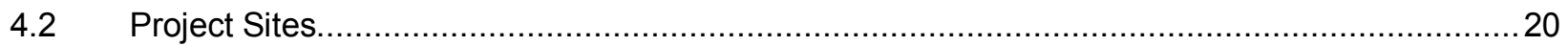

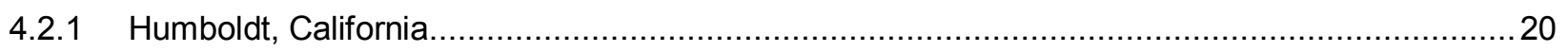

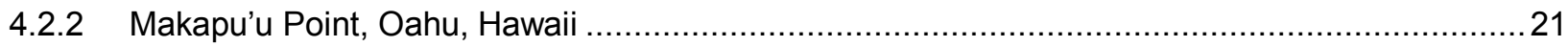

4.3 Environmental Effects Analysis: Wave Project Scenarios .................................................. 22

4.3.3 Small commercial scale OPT Power Buoy Project at Humboldt ............................................2 23

4.3.4 Application of a small commercial scale OPT Power Buoy wave project to other Humboldt

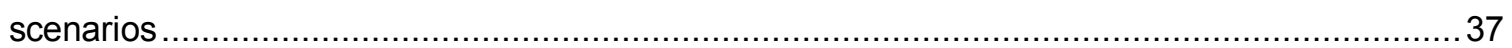

4.3.5 Small commercial scale Pelamis Wave Power P-2 project at Makapu'u ................................... 39

4.3.6 Application of a small commercial scale Pelamis Wave Power P-2 Project at Makapu'u to

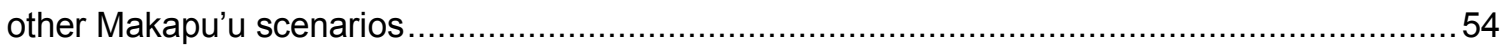

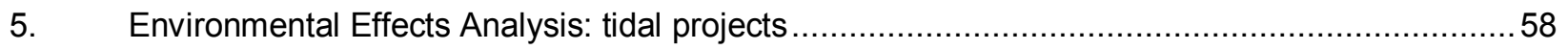

5.1 Summary Description of Tidal Energy Technologies .......................................................... 58

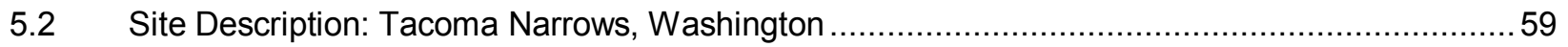

5.3 Environmental Effects Analysis: Pilot scale MCT SeaGen project at Tacoma Narrows...............60

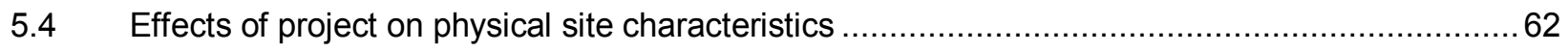

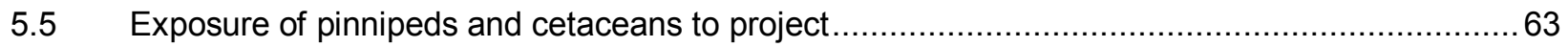

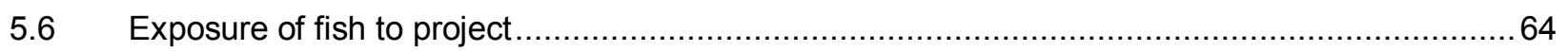

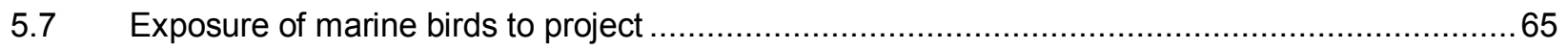

5.8 Overall risk to indicators for a pilot scale MCT SeaGen project at Tacoma Narrows ...................66

5.9 Priority studies warranted for a pilot scale MCT SeaGen project at Tacoma Narrows................ 72

5.10 Application of a pilot scale MCT SeaGen project to other Tacoma scenarios ..........................72

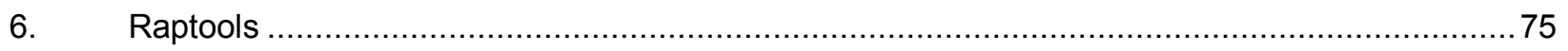

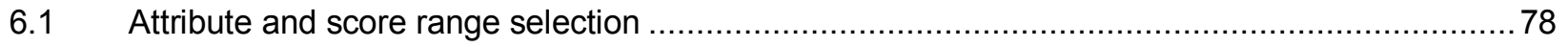

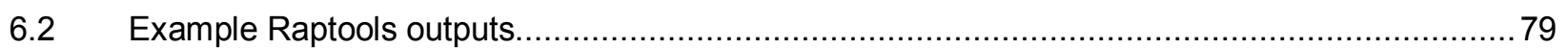

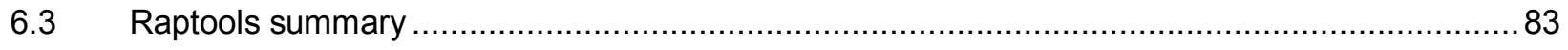

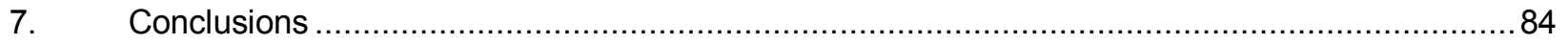

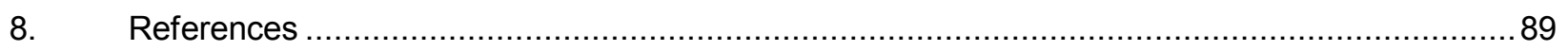




\section{List of Tables}

Table 1- Subset of literature consulted to identify generic potential effects .................................... 5

Table 2 - Actions common to all wave and tidal projects, their potential environmental effects, and the physical attributes and organism groups affected. Specific effects depend on

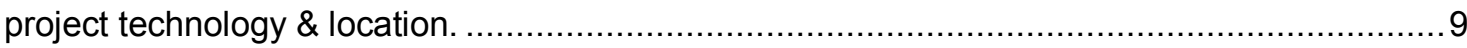

Table 3 - Project and technology description information needed for construction, operations \& maintenance, and decommissioning phases. One table would be needed for each type of technology under consideration

Table 4 - Exposure of biological indicator to project actions....................................................... 16

Table 5 - Potential project effects on site physical characteristics ............................................... 17

Table 6 - Evaluation of overall exposure and risk to indicators by project action and activity................ 17

Table 7 - Devices chosen for scenario-based analysis ............................................................ 19

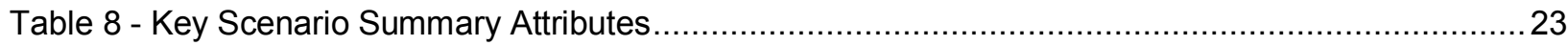

Table 9 - Summary of exposure (medium, high or unknown) of cetacean and pinniped indicator species to a small commercial scale OPT Power Buoy wave project.

Table 10 - Summary of exposure (medium, high, unknown) of fish indicators to a small commercial scale OPT Power Buoy wave project.

Table 11 - Summary of exposure (medium, high, unknown) of marine bird indicators to a small commercial scale OPT Power Buoy wave project.

Table 12 - Summary of exposure (medium, high, unknown) of Dungeness crab to a small commercial scale OPT Power Buoy wave project.

Table 13 - Overall risk (medium, high, unknown) to site physical characteristics due to a small commercial OPT Power Buoy project at the Humboldt site.

Table 14 - Overall risk (medium, high, unknown) to indicator species or species groups due to a small commercial OPT Power Buoy project at the Humboldt site.

Table 15 - Possible future studies warranted for a small commercial scale OPT Power Buoys at Humboldt site

Table 16 - Summary table of small commercial Pelamis array deployed at Waimanalo Bay in Hawaii

Table 17 - Summary of exposure (medium, high, unknown) of cetaceans and pinnipeds to a small commercial scale Pelamis Wave Power P-2 project at Makapu'u.

Table 18 - Summary of exposure (medium, high, unknown) of fish indicators to a small commercial scale Pelamis Wave Power P-2 project at Makapu'u. 
Table 19 - Summary of exposure (medium, high, unknown) of sea turtles to a small commercial scale Pelamis Wave Power P-2 project at Makapu'u.

Table 20 - Summary of exposure (medium, high, unknown) of marine bird indicators to a small commercial scale Pelamis Wave Power P-2 project at Makapu'u.

Table 21 - Summary of exposure (medium, high, unknown) of coral reefs to a small commercial scale Pelamis Wave Power P-2 project at Makapu'u.

Table 22 - Overall risk (medium, high, unknown) to site physical characteristics for a small commercial scale Pelamis Wave Power P-2 project at the Makapu'u site.

Table 23 - Overall risk (medium, high, unknown) to indicator species or species groups for a small commercial Pelamis P-2 project at the Makapu'u site.

Table 24 - Possible future studies warranted for small commercial scale Pelamis Wave Power P2 project at Makapu'u site .54

Table 25 - Selected tidal power technologies

Table 26 - MCT scenario attributes

Table 27 - Summary of exposure (medium, high, unknown) of cetaceans and pinnipeds to a pilot scale MCT SeaGen project at Tacoma Narrows.

Table 28 - Summary of exposure to a pilot scale MCT SeaGen project at Tacoma Narrows with a med, high, or unknown overlap with fish indicators from the effects analysis tables.

Table 29 - Summary of exposure (medium, high, unknown) of marine bird indicators to a pilot scale MCT SeaGen project at Tacoma Narrows.

Table 30 - Overall risk (medium, high, unknown) to site physical characteristics for a pilot scale MCT SeaGen project at the Tacoma Narrows.

Table 31 - Overall risk (medium, high, unknown) to indicator species or species groups for a pilot scale MCT SeaGen project at the Tacoma Narrows.

Table 32 - Possible future studies warranted for pilot scale MCT SeaGen project at the Tacoma site

Table 33 - Questions addressed in this trial Raptools application 79

Table 34. Key environmental concerns and next steps 


\section{List of Figures}

Figure 1 - Humboldt, California project site (Previsic 2009a).................................................... 21

Figure 2 - Makapu'u Point, Oahu, Hawaii project site (Previsic 2009b).......................................... 22

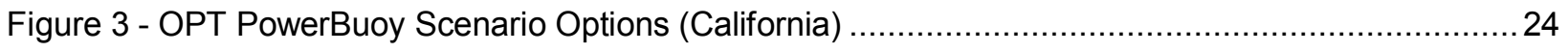

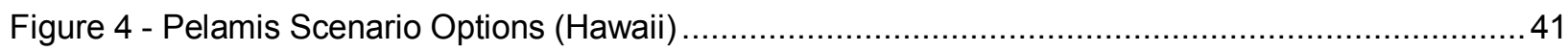

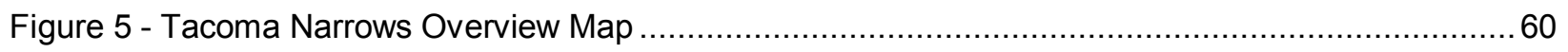

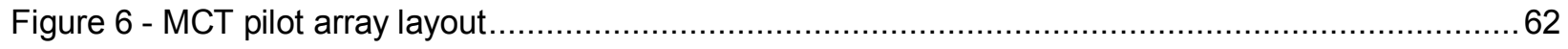

Figure 7 - Raptools $\mathrm{X}-\mathrm{Y}$ ordination graph resulting from trial run of siting attributes............................. 80

Figure 8 - The Makapu'u site generally presents the fewest adverse effects, based on trial run

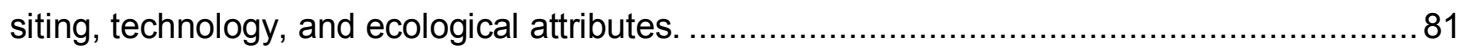




\section{Introduction}

Marine wave and tidal energy technology could interact with marine resources in ways that are not well understood. As wave and tidal energy conversion projects are planned, tested, and deployed, a wide range of stakeholders will be engaged; these include developers, state and federal regulatory agencies, environmental groups, tribal governments, recreational and commercial fishermen, and local communities. Identifying stakeholders' environmental concerns in the early stages of the industry's development will help developers address and minimize potential environmental effects. Identifying important concerns will also assist with streamlining siting and associated permitting processes, which are considered key hurdles by the industry in the U.S. today.

In September 2008, RE Vision consulting, LLC was selected by the Department of Energy (DoE) to conduct a scenario-based evaluation of emerging hydrokinetic technologies. The purpose of this evaluation is to identify and characterize environmental impacts that are likely to occur, demonstrate a process for analyzing these impacts, identify the "key" environmental concerns for each scenario, identify areas of uncertainty, and describe studies that could address that uncertainty. This process is intended to provide an objective and transparent tool to assist in decision-making for siting and selection of technology for wave and tidal energy development. RE Vision worked with H. T. Harvey \& Associates, to develop a framework for identifying key environmental concerns with marine renewable technology. This report describes the results of this study.

This framework was applied to varying wave and tidal power conversion technologies, scales, and locations. The following wave and tidal energy scenarios were considered:

- 4 wave energy generation technologies

- 3 tidal energy generation technologies

- 3 sites: Humboldt coast, California (wave); Makapu'u Point, Oahu, Hawaii (wave); and the Tacoma Narrows, Washington (tidal)

- 3 project sizes: pilot, small commercial, and large commercial

The possible combinations total 24 wave technology scenarios and 9 tidal technology scenarios. We evaluated 3 of the 33 scenarios in detail:

1. A small commercial OPT Power Buoy project off the Humboldt County, California coast

2. A small commercial Pelamis Wave Power P-2 project off Makapu'u Point, Oahu, Hawaii

3. A pilot MCT SeaGen tidal project, sited in the Tacoma Narrows, Washington 
This framework document used information available from permitting documents that were written to support actual wave or tidal energy projects, but the results obtained here should not be confused with those of the permitting documents ${ }^{1}$. The main difference between this framework document and permitting documents of currently proposed pilot projects is that this framework identifies key environmental concerns and describes the next steps in addressing those concerns; permitting documents must identify effects, find or declare thresholds of significance, evaluate the effects against the thresholds, and find mitigation measures that will minimize or avoid the effects so they can be considered less-thansignificant.

Two methodologies, 1) an environmental effects analysis and 2) Raptools, were developed and tested to identify potential environmental effects associated with wave or tidal energy conversion projects. For the environmental effects analysis, we developed a framework based on standard risk assessment techniques. The framework was applied to the three scenarios listed above. The environmental effects analysis addressed questions such as:

- What is the temporal and spatial exposure of a species at a site?

- What are the specific potential project effects on that species?

- What measures could minimize, mitigate, or eliminate negative effects?

- Are there potential effects of the project, or species' response to the effect, that are highly uncertain and warrant additional study?

The second methodology, Raptools, is a collaborative approach useful for evaluating multiple characteristics of numerous siting or technology alternatives, and it allows us to graphically compare alternatives. We used Raptools to answer these questions:

- How do the scenarios compare, in terms of exposure, risks, and effects to the ecological and human environments?

- Are there sites that seem to present the fewest effects regardless of technology and scale?

- Which attributes account for many or much of the effects associated with wave or tidal energy development?

\footnotetext{
${ }^{1}$ In particular, the scenario-based risk evaluations done for individual indicators in this framework should not be confused with declarations of less-than-significant effects on resources in the NEPA Environmental Assessment for the project in Kaneohe Bay, Hawaii, or the FERC license application documents for projects near Humboldt County, California, or Snohomish County, Washington.
} 
Other questions, such as what are the cumulative effects of many marine renewable projects, or how does global climate change add to potential effects of marine renewable projects, could also be answered using Raptools. To answer the three questions above, we performed a trial run of the Raptools method using all 33 scenarios (See Section 6).

Effects are generally classified as direct, indirect, and cumulative. In this report, we focus on direct effects and "reasonably-expected-to-occur" indirect effects (for example, effects on predator-prey relationships are considered because the creation of artificial reef effects from underwater wave energy structures is reasonably expected). Cumulative effects are included as they relate to project size, however, other causes of cumulative effects (for example, global climate change or multiple projects) were considered beyond the scope of this study.

As mentioned above, three wave and tidal energy pilot projects have been proposed in the regions that we evaluated; these include PG\&E WaveConnect off the Humboldt County coast, California; Snohomish Public Utility District \#1 in Admiralty Inlet, Puget Sound, Washington; and Marine Corps Base Hawaii at Kaneohe Bay, Hawaii. We reiterate that effects evaluations from permitting documents from those three projects are not comparable to this framework for many reasons, including:

- This framework identifies key environmental concerns and uncertainties, and highlights "next steps" to take to continue development and adoption of marine renewable energy. Permitting documents identify effects, incorporate mitigations measures to reduce or avoid effects, propose thresholds of significance, and declare whether the mitigated effects are significant or less than significant after the mitigation measures.

- This framework considers pilot, small commercial, and large commercial projects; the permitting documents describe the effects of pilot scale projects

- This framework considers projects that last for up to 20 years, and includes decommissioning actions and effects; the permitting documents describe shorter term projects. 


\section{Generic Wave and Tidal Energy Development Effects}

Wave and tidal energy projects will likely have common elements that result in similar environmental effects; these "generic" potential effects provide a framework for evaluating exposures and risks associated with projects. Our selection of generic environmental effects is based on growing body of literature (Table 1). An example of a generic effect is the artificial reef effect expected when any artificial structure is deployed on a relatively low-relief seafloor. Marine organisms often colonize artificial structures, which then begin to function much as a natural reef. An artificial reef effect is expected regardless of project size, location, or technology (that is, the probability of occurrence is high), although the effect's magnitude may vary with project size, setting, location and duration (its spatial and temporal exposure will be site and technology dependent).

Table 1- Subset of literature consulted to identify generic potential effects

\begin{tabular}{|l|l|}
\hline \multicolumn{1}{|c|}{ Author citation } & \multicolumn{1}{c|}{ Title of Report or Article } \\
\hline Boehlert et al. 2008 & Ecological effects of wave energy development in the Pacific Northwest. \\
\hline Cada 2008 & $\begin{array}{l}\text { The potential environmental impacts of marine and hydrokinetic renewable energy } \\
\text { technologies. }\end{array}$ \\
\hline EMEC 2005 & $\begin{array}{l}\text { Environmental Impact Assessment (EIA) guidance for developers at the European } \\
\text { Marine Energy Centre }\end{array}$ \\
\hline Gill 2005 & $\begin{array}{l}\text { Offshore renewable energy: ecological implications of generating electricity in the } \\
\text { coastal zone. }\end{array}$ \\
\hline Michel et al. 2007 & $\begin{array}{l}\text { Worldwide synthesis and analysis of existing information regarding environmental } \\
\text { effects of alternative energy uses on the Outer Continental Shelf. }\end{array}$ \\
\hline MMS 2007 & $\begin{array}{l}\text { Programmatic Environmental Impact Statement for alternative energy } \\
\text { development and production and alternate use of facilities on the Outer } \\
\text { Continental Shelf. }\end{array}$ \\
\hline Nelson et al. 2008 & $\begin{array}{l}\text { Developing wave energy in coastal California: potential socio-economic and } \\
\text { environmental effects. }\end{array}$ \\
\hline
\end{tabular}

Effects may occur on biological or physical environmental attributes. An example of an effect on a physical attribute is the change in bottom substrate due to the device foundations. For example, if large concrete foundations are needed to anchor the devices on a sandy or muddy coastal shelf, the foundations would add hard structure to the sand/mud bottom. Biological and physical effects are often compounded (for example, a physical change on the seabed surface causes a change in benthic invertebrate distribution), yet to begin an analysis or evaluation of effects, we grouped and defined representative physical and biological environmental attributes. 


\subsection{Potentially affected physical attributes and marine organism groups}

To describe potential effects from wave or tidal projects, we selected representative physical attributes and marine organism groups. The potential number of physical attributes and organisms that could be affected by wave or tidal projects is large, so selecting representative attributes was necessary. We selected the following site physical attributes (Faber Maunsell and Metoc PLC 2007, Nelson et al. 2008):

- Substrate grain size

- Sediment transport

- Sediment chemistry

- Water chemistry

- Littoral cell dynamics

- Acoustic environment

- Visual environment

- Electromagnetic environment

- Wave or tidal energy environment

Hundreds (if not thousands) of individual species are potentially affected by offshore structures. For this description of generic effects, we classified species into the following marine organism groups:

- marine birds (seabirds and ducks),

- cetaceans (whales, dolphins, and porpoises),

- pinnipeds (seals and sea lions),

- mustelids (otters)

- fishes (benthic and pelagic),

- invertebrates (benthic, pelagic, and biofouling), and

- sea turtles

Sea grasses or marine algae were not included because we assumed that most projects will have negligible and unmeasurable direct and indirect effects on them. Macroalgae generally require hard substrate (Schiel and Foster 1986), whereas most projects are likely to be deployed on low-relief, soft substrates. Most macroalgae and all sea grasses occur in comparatively shallower waters, usually less than $30 \mathrm{~m}$ (Schiel and Foster 1986); however, some macroalgae can occur at depths that projects could be deployed (Clokie et al. 1981; Littler et al. 1985; Aponte and Ballantine 2001). Deepwater (>100 m) macroalgae (e.g., crustose coralline algae) can occur in appreciable densities (Littler et al. 1985; Aponte and Ballantine 2001; Graham et al. 2007), but these are assumed to be comparatively rare and isolated. Because most projects are likely to be deployed at depths greater than those associated with dense assemblages of 
macroalgae, direct effects are unlikely; projects will likely be deeper than the shallow water habitat of sea grasses, so again, direct effects are unlikely. While indirect effects are a possible due to reduced wave energies or tidal currents (Duggins et al. 2003), the natural variability of wave forces and the low magnitude of the expected change in wave energies or tidal currents are likely to render any ecological effects undetectable and unmeasurable (Eckman et al. 2003).

\subsection{Generic project actions and their potential effects}

Generic project actions and potential effects are briefly described below.

Noise and vibration - Noise and vibration are associated with construction activities, such as drilling into the seabed for foundation installation or directional drilling and trenching for the transmission cable, and/or operation of wave or tidal energy conversion devices. These in-water and below surface vibrations could disturb marine birds, cetaceans, pinnipeds, and fish, which use sound for communication, prey or predator location, and/or echolocation (Evans III and Norris 1988, Gill 2005, Hastings and Popper 2005, Kalmijn 1989, Lobel 1992, Mann et al. 2007, Myrberg Jr. 1990, Norris and Evans III 1988, Sara et al. 2007, Tricas et al. 2006). Noise and vibration effects are dependent on the characteristics of the noise (i.e., amplitude and frequency), weather, sea conditions, and ambient noise due to natural processes and anthropogenic activities.

Seabed disturbance - The seabed will be temporarily disturbed from laying or trenching transmission cable, installing foundations or anchors for wave or tidal energy conversion devices, and from scouring around moorings due to localized water circulation. Seabed disturbance could result in high levels of turbidity, and changes in sediment chemistry if pollutants become mobilized or if sediment oxidationreduction conditions are disrupted (Gill 2005). Increased turbidity could disrupt benthic spawning activities of fish and invertebrates, and could smother benthic invertebrates including coral reefs (Gill 2005). Seabed disturbance could impact marine birds by temporarily impacting local food availability.

Structure - Structures will attract fish species and provide substrate for sessile invertebrates (Bohnsack et al. 1991, Svane and Petersen 2001). As a result, structures could cause physical and biological effects such as changes in food availability, species composition, predator/prey interactions, and competition between species. Direct effects due to underwater and surface structures include direct impact or collision, altering animals' movement patterns, providing haul out and roosting sites, and providing foraging habitat. Structures can serve as resting platforms for marine birds and/or pinnipeds, resulting in behavioral 
changes or changes to their local distribution. Structures may also entangle marine debris (e.g., fishing nets, crab gear) that in turn may entangle animals.

Moving parts - Pinnipeds, cetaceans, fish, and/or diving marine birds could collide with, be caught by, or impinged on underwater moving parts of wave or tidal energy conversion devices (for example, turbines or hinges) causing mortality or injury (Cada et al. 2007).

Water circulation changes - Wave or tidal energy conversion devices could decrease wave or tidal current energy, which could alter sediment transport and depositional processes. Changes in circulation could alter sediment transport and beach processes, and affect bays, inlets, and estuaries that are sensitive to sand dynamics; for example, bar dynamics of estuaries could change, which could increase or decrease exchange of brackish and sea water (Largier et al. 2008). Tidal energy extraction could also affect tidal range and mixing (Polagye 2009a). Sediment size, volume, and chemistry could be affected by changes in circulation. These changes could indirectly alter habitat and/or affect availability and distribution of food resources for a wide variety of marine organisms.

Electromagnetic field (EMF) - Cables that transmit alternating and direct current from the wave or tidal energy conversion devices to the mainland could interact with species that are sensitive to electric and magnetic fields. Cable insulation and/or burial can be effective on the electric fields associated with alternative current transmission, but insulation is not complete on the magnetic fields (Gill 2005). The magnetic field leakage could result in induced electric fields. The electromagnetic field emissions are within the range of those utilized by species sensitive to electric and magnetic fields such as elasmobranches, sturgeons, salmonids, and marine mammals (Boehlert et al. 2008, Nelson et al. 2008). Electromagnetic fields associated with direct current cables have not yet been determined in the context of offshore renewable energy development (Gill 2005).

Lights - Marine birds can be attracted to or confused by lights; they can either collide with lighted structures or become exhausted by continual flying to and around the lights (Black 2005, Bruderer et al. 1999). Navigation lights are associated with boats used during construction, maintenance, and decommissioning activities; navigational lights will also be installed on the wave or tidal energy conversion devices. Construction and decommissioning lights are expected to be significantly brighter than navigational lights but they would be temporary; navigational lights on the devices would be present for the duration of the project. Depending on intensity, color, and pattern, lights could attract marine birds and some species of fish and pelagic invertebrates. 
Chemical releases - Oil and other chemicals (e.g., hydraulic fluids, antifouling paint, fuel) used during construction, operation and maintenance, and decommissioning could be accidentally released into the marine environment. Changes in the physical environment from such releases would depend on the type, volume, and rate of chemical release. Chemicals could be ingested and become toxic to a host of marine organisms. For example, marine birds that get oil on their feathers lose feather waterproofing, causing hypothermia and other physiological effects associated with ingestion of toxic chemicals during preening. These effects would likely be temporary, as chemical releases would eventually dissipate; the duration of effects would depend on the size of the release.

Generic project effects were systematically considered for the physical attributes and the marine organism groups listed above; these are summarized in Table 2 (see Appendix A for full analysis). Through those tables, we were able to identify wave and tidal energy project activities (such as construction using boats) and actions that could potentially affect marine organisms (such as direct impact or oil/chemical release).

Table 2 - Actions common to all wave and tidal projects, their potential environmental effects, and the physical attributes and organism groups affected. Specific effects depend on project technology \& location.

\begin{tabular}{|c|c|c|c|}
\hline Project activity & Action & $\begin{array}{l}\text { Site physical attributes } \\
\text { potentially affected }\end{array}$ & $\begin{array}{l}\text { Organism groups potentially } \\
\text { affected }\end{array}$ \\
\hline \multicolumn{4}{|c|}{ Project Phase: Construction } \\
\hline \multirow{4}{*}{ Boat traffic } & Direct impact & None identified & Cetaceans, pinnipeds, sea turtles \\
\hline & Noise and vibration & Acoustic environment & $\begin{array}{l}\text { Marine birds, cetaceans, } \\
\text { pinnipeds, fish, sea turtles }\end{array}$ \\
\hline & Oil/chemical release & Sediment and water chemistry & $\begin{array}{l}\text { Marine birds, cetaceans, } \\
\text { pinnipeds, mustelids, fish, } \\
\text { invertebrates, sea turtles }\end{array}$ \\
\hline & Navigation lights & Visual environment & None \\
\hline \multirow{4}{*}{$\begin{array}{l}\text { Construction of } \\
\text { electrical collector } \\
\text { system, moorings } \\
\text { and foundations, } \\
\text { and device } \\
\text { installation }\end{array}$} & Noise and vibration & Acoustic environment & $\begin{array}{l}\text { Marine birds, cetaceans, } \\
\text { pinnipeds, fish, sea turtles }\end{array}$ \\
\hline & Oil/chemical release & Sediment and water chemistry & $\begin{array}{l}\text { Marine birds, cetaceans, } \\
\text { mustelids, pinnipeds, fish, } \\
\text { invertebrates, sea turtles, }\end{array}$ \\
\hline & Seabed disturbance & $\begin{array}{l}\text { Substrate size, sediment and } \\
\text { water chemistry }\end{array}$ & $\begin{array}{l}\text { Marine birds, invertebrates, fish, } \\
\text { sea turtles }\end{array}$ \\
\hline & $\begin{array}{l}\text { Construction and } \\
\text { deck lights }\end{array}$ & Visual environment & $\begin{array}{l}\text { Marine birds, cetaceans, } \\
\text { pinnipeds, fish, invertebrates, } \\
\text { sea turtles }\end{array}$ \\
\hline
\end{tabular}




\begin{tabular}{|c|c|c|c|}
\hline \multirow{2}{*}{$\begin{array}{l}\text { Directional drilling, } \\
\text { and laying cable } \\
\text { under/on seabed }\end{array}$} & Seabed disturbance & $\begin{array}{l}\text { Substrate size, sediment and } \\
\text { water chemistry }\end{array}$ & $\begin{array}{l}\text { Marine birds, invertebrates, fish, } \\
\text { sea turtles }\end{array}$ \\
\hline & Noise and vibration & Acoustic environment & $\begin{array}{l}\text { Marine birds, cetaceans, } \\
\text { pinnipeds, fish, sea turtles }\end{array}$ \\
\hline \multicolumn{4}{|c|}{ Project Phase: Operation and Maintenance } \\
\hline \multirow{4}{*}{ Boat traffic } & Direct impact & None identified & Cetaceans, pinnipeds, sea turtles \\
\hline & Oil/chemical release & Sediment and water chemistry & $\begin{array}{l}\text { Marine birds, cetaceans, } \\
\text { pinnipeds, mustelids, fish, } \\
\text { invertebrates, sea turtles }\end{array}$ \\
\hline & Noise and vibration & Acoustic environment & $\begin{array}{l}\text { Marine birds, cetaceans, } \\
\text { pinnipeds, fish, sea turtles }\end{array}$ \\
\hline & Navigation lights & Visual environment & None \\
\hline \multirow{3}{*}{$\begin{array}{l}\text { Operation of } \\
\text { turbines or other } \\
\text { moving parts of } \\
\text { devices }\end{array}$} & Moving device parts & None identified & $\begin{array}{l}\text { Marine birds, cetaceans, } \\
\text { pinnipeds, fish, sea turtles }\end{array}$ \\
\hline & Noise and vibration & Acoustic environment & $\begin{array}{l}\text { Marine birds, cetaceans, } \\
\text { pinnipeds, fish, sea turtles }\end{array}$ \\
\hline & Absorbing energy & Wave or tidal energy environ. & Invertebrates \\
\hline \multicolumn{4}{|c|}{ Project Phase: Operation and Maintenance } \\
\hline \multirow{3}{*}{$\begin{array}{l}\text { Structures in water } \\
\text { column and on } \\
\text { seabed, such as } \\
\text { devices and } \\
\text { moorings and } \\
\text { footings }\end{array}$} & Structure & $\begin{array}{l}\text { Substrate size, sediment } \\
\text { chemistry }\end{array}$ & $\begin{array}{l}\text { Marine birds, invertebrates, fish, } \\
\text { cetaceans, pinnipeds, sea turtles }\end{array}$ \\
\hline & $\begin{array}{l}\text { Water circulation } \\
\text { changes }\end{array}$ & $\begin{array}{l}\text { Substrate size, sediment } \\
\text { volume, sediment and water } \\
\text { chemistry, littoral cell dynamics }\end{array}$ & $\begin{array}{l}\text { Marine birds, invertebrates, fish, } \\
\text { sea turtles }\end{array}$ \\
\hline & Oil/chemical release & Sediment and water chemistry & $\begin{array}{l}\text { Marine birds, cetaceans, } \\
\text { pinnipeds, mustelids, fish, } \\
\text { invertebrates, sea turtles }\end{array}$ \\
\hline $\begin{array}{l}\text { Electricity } \\
\text { conduction through } \\
\text { cable }\end{array}$ & EMF & Electro-magnetic environment & $\begin{array}{l}\text { Cetaceans, pinnipeds, fish, } \\
\text { invertebrates, sea turtles }\end{array}$ \\
\hline \multirow{2}{*}{$\begin{array}{l}\text { Structures on } \\
\text { water's surface }\end{array}$} & Structure & $\begin{array}{l}\text { Substrate size, sediment } \\
\text { chemistry, visual environment }\end{array}$ & $\begin{array}{l}\text { Marine birds, cetaceans, } \\
\text { pinnipeds, fish, invertebrates, } \\
\text { sea turtles }\end{array}$ \\
\hline & Navigation lights & Visual environment & $\begin{array}{l}\text { Marine birds, cetaceans, } \\
\text { pinnipeds, fish, invertebrates, } \\
\text { sea turtles }\end{array}$ \\
\hline \multicolumn{4}{|c|}{ Project Phase: Decommissioning } \\
\hline Boat traffic & Direct impact & None identified & Cetaceans, pinnipeds, sea turtles \\
\hline
\end{tabular}




\begin{tabular}{|c|c|c|c|}
\hline & Oil/chemical release & Sediment and water chemistry & $\begin{array}{l}\text { Marine birds, cetaceans, } \\
\text { pinnipeds, mustelids, fish, } \\
\text { invertebrates, sea turtles }\end{array}$ \\
\hline & Noise and vibration & Acoustic environment & $\begin{array}{l}\text { Marine birds, cetaceans, } \\
\text { pinnipeds, fish, sea turtles }\end{array}$ \\
\hline & Navigation lights & Visual environment & None \\
\hline \multirow{4}{*}{$\begin{array}{l}\text { Decommissioning } \\
\text { and removal of } \\
\text { electrical collector } \\
\text { system, subsea } \\
\text { cable, mooring } \\
\text { cables, foundations } \\
\text { or anchors, and } \\
\text { devices }\end{array}$} & Noise and vibration & Acoustic environment & $\begin{array}{l}\text { Marine birds, cetaceans, } \\
\text { pinnipeds, fish, sea turtles }\end{array}$ \\
\hline & Oil/chemical release & Sediment and water chemistry & $\begin{array}{l}\text { Marine birds, cetaceans, } \\
\text { pinnipeds, mustelids, fish, } \\
\text { invertebrates, sea turtles }\end{array}$ \\
\hline & Seabed disturbance & $\begin{array}{l}\text { Substrate size, sediment and } \\
\text { water chemistry }\end{array}$ & $\begin{array}{l}\text { Marine birds, invertebrates, fish, } \\
\text { sea turtles }\end{array}$ \\
\hline & $\begin{array}{l}\text { Deconstruction and } \\
\text { deck lights }\end{array}$ & Visual environment & $\begin{array}{l}\text { Marine birds, cetaceans, } \\
\text { pinnipeds, fish, invertebrates, } \\
\text { sea turtles }\end{array}$ \\
\hline
\end{tabular}

The above actions are generic and common to all projects, but their frequency, magnitude, and significance of effects on the physical environment and marine organisms will vary, depending on the species exposure and its probability of occurrence. For example, ocean floor disturbance from installing the transmission cable is an action common to most projects (high probability of occurring). However, its effect on benthic invertebrates may be less than significant and temporary if the location is in a littoral cell $^{2}$ with very high sediment transport rates or where substrates do not support diverse or abundant benthic invertebrates (low exposure), whereas its effects could be far more significant to coral reefs (high exposure). In addition, many of these actions associated with construction, maintenance, and decommissioning activities are short-term, so the potential effects on the physical environment and marine environment may not be significant because they are temporary; therefore, the duration (i.e., shortterm, long-term, or permanent) of actions and effects also needs to be considered when analyzing potential effects of wave and tidal projects. The above generic effects do not describe technology specific effects; an example of a technology specific effect is larval fish entrainment, which could occur when deploying an overtopping-type wave energy conversion device. While discussion of generic effects is needed to anticipate potential effects during initial planning stages, one should apply the following environmental assessment methodology to identify and evaluate effects at specific sites from specific energy technologies.

${ }^{2}$ A littoral cell is "a self-contained shoreline sediment system that has no movement of sediment across its boundaries" (OMNR 2008). 


\section{Environmental Assessment Methodology}

This environmental assessment methodology is intended to be a versatile tool that is broadly applicable to many energy development programs. Most environmental assessments begin with data collection, project and environment description, and fact-finding, and this methodology is similar to others in that respect. Our primary approach in this project was to evaluate potential environmental effects of 4 wave technologies, 3 tidal technologies, 3 potential sites, and 3 project scales. We followed these steps in this environmental effects analysis for siting wave and tidal energy development:

Step 1. Describe the wave or tidal energy technologies of interest.

Step 2. Describe the sites' affected environments

Step 3. Perform environmental effects analysis

\subsection{Describe Potential Technologies and their Actions}

To assess environmental exposure, risks, and potential effects associated with wave and tidal energy conversion technologies, the technologies should be described, including detailed information about all phases and activities of a given project utilizing those technologies such as construction, operation and maintenance, and decommissioning. Detailed project/technology descriptions are important because actions and effects could be overlooked if a project activity is not adequately described. To assist in obtaining a thorough and complete project and technology description, we developed a table that includes major project activities associated with all technologies (Table 3). If all cells are filled, much of the required project description data will have been obtained.

Table 3 - Project and technology description information needed for construction, operations \& maintenance, and decommissioning phases. One table would be needed for each type of technology under consideration.

\begin{tabular}{|l|l|}
\hline Project phase & Project activity or characteristic \\
\hline \multirow{5}{*}{ Construction } & Location and deployment depths \\
\cline { 2 - 3 } & Footprint \\
\cline { 2 - 2 } & Loading ports and dock locations \\
\cline { 2 - 2 } & Shipping routes for delivery and installation \\
\cline { 2 - 2 } & Ship types and sizes \\
\cline { 2 - 2 } & Installation and assembly procedures \\
\cline { 2 - 2 } & Installation equipment \\
\cline { 2 - 2 } & Temporary structures \\
\cline { 2 - 2 } & Types, composition, locations, and numbers of anchoring and mooring systems \\
\cline { 2 - 2 } & Installation schedule and phasing \\
\cline { 2 - 2 } & Chemicals and fuels used \\
\hline
\end{tabular}




\begin{tabular}{|c|c|}
\hline Project phase & Project activity or characteristic \\
\hline & Sources and levels of noise \\
\hline & Sources, levels, and characteristics of light \\
\hline & Number of vessel trips \\
\hline \multirow{12}{*}{ Operations and Maintenance } & General description of technology \\
\hline & O\&M procedures and schedule \\
\hline & Operating equipment other than wave/tidal device(s) \\
\hline & Listing of all moving parts and impingement surfaces \\
\hline & Listing of all structures on surface and below \\
\hline & Vessel routes and schedule for operation and maintenance \\
\hline & Ship types and sizes \\
\hline & Potential emergency conditions and procedures \\
\hline & Chemicals used by devices, e.g., hydraulic fluids, antifouling paints. \\
\hline & Sources and levels of noise \\
\hline & Sources, levels and characteristics of light \\
\hline & EMF field strength \\
\hline \multirow{14}{*}{ Decommissioning } & Description of equipment or structures removed \\
\hline & Description of equipment or structures to be left in place \\
\hline & Monitoring procedure and schedule for equipment left in place \\
\hline & Shipping routes for equipment removed \\
\hline & Ship types and size \\
\hline & Decommissioning and dis-assembly procedures \\
\hline & Decommissioning equipment \\
\hline & Temporary structures \\
\hline & Decommissioning schedule and phasing \\
\hline & Chemicals and fuels used \\
\hline & Sources and levels of noise \\
\hline & Sources, levels, and characteristics of lights \\
\hline & Vessels required, number of trips \\
\hline & Best management practices planned \\
\hline
\end{tabular}

The level of detail required may seem onerous, but is necessary to evaluate potential effects on site physical characteristics and on marine organisms. If detailed information is not available environmental effects analyses can still be performed using assumptions that will need to be verified later.

\subsection{Describe the Affected Environment of Potential Sites}

To assess the environmental effects of a wave or tidal energy project, the physical environment and the potentially affected marine organisms must be described. The areal extent of the affected environment to be described depends on the extent of direct potential effects; we define the affected environment to be 
the area that contains physical characteristics and marine organisms that could be directly affected by the project.

\subsection{Criteria for defining the extent of the affected physical environment}

The extent and characteristics of the physical environment most likely affected by the project should be defined. Criteria for defining the affected physical environment include:

- Footprint of the project

- Extent or size of energy conversion devices, including their associated mooring gear

- Routes required for ship transportation of structures and equipment associated with the project

- Extent and location of any direct physical effects from the project (e.g., changes in sediment transport, noise or tidal/wave energy)

- Location of any socio-political boundaries such as jurisdictional boundaries, designated areas of special concern, prime fishing areas, or marine reserves that occur within the affected physical environment

Based on our analysis of generic effects, the site physical attributes that could be affected include (Section 2.1):

- Substrate grain size

- Sediment transport

- Sediment chemistry

- Water chemistry

- Littoral cell dynamics

- Acoustic environment

- Visual environment

- Electromagnetic environment

- Wave or tidal energy environment

\subsection{Criteria for selecting biological indicators}

After defining the extent of the affected physical environment, potentially affected organisms that occur within this physical environment should be identified. Of these organisms, specific biological indicators should be selected to evaluate the range of potential environmental effects of the project. Biological indicators could include species, species assemblages or groups, and/or the habitats that they depend on. 
Five criteria for selecting biological indicators include:

- The species/species assemblage occurs in the project area. Species occurring can be determined from distribution and range maps, scientific literature, and monitoring reports. State and federal agency scientists and species-group experts should be consulted, and the species life stages and their temporal distributions (e.g., seasonal distributions) should be determined.

- The species/species assemblage, primary prey species, or habitat could be affected by the project, at some point during the project life cycle (construction, operation, and decommissioning). Effects may be long-term or short-term, reversible or irreversible, and/or cumulative. Ecosystem-level effects should also be considered such as potential changes in community composition, prey availability or predator abundance, or habitat.

- Species or habitats that are subject to Federal and state regulations.

- The species is important based on input from the public and stakeholders such as tribes, fishermen, tourists, surfers, boaters, resource managers, and scientists. Indicators might include species with special cultural associations, charismatic or iconic species, and species that are fished or harvested, or observed through tourism.

- Effects on the species can be measured and evaluated. Without means to measure and evaluate the effect on a species, its use as an indicator is extremely limited.

Any Federally threatened or endangered species should be considered an indicator species because consultation with the U.S. Fish and Wildlife Service (USFWS) or the National Marine Fisheries Service (NMFS) would be required to evaluate potential effects on the listed species and determine ways to minimize or avoid impacts in order for the project to be permitted; marine mammals protected by the Marine Mammal Protection Act should also be considered. USFWS has jurisdiction over terrestrial animals and plants, birds, and freshwater fishes (information is available at http://ecos.fws.gov/ecos_public); NMFS has jurisdiction over marine mammals, marine reptiles, and marine and anadromous fishes (information is available at http://www.nmfs.noaa.gov/pr/species/). Species that are State-listed as threatened or endangered or are species of special concern should also be considered as indicators because their populations are known to be declining and the state may be required to evaluate impacts for the project to be permitted. Essential fish habitats (EFH) in the project area should be included as indicators because consultation with NMFS would be required to minimize or avoid impacts to fish habitat. EFH is defined as those areas that are necessary to fish for their basic life functions (information is available at http://www.nmfs.noaa.gov/habitat/habitatprotection/efh/index.htm). 


\subsection{Perform Environmental Effects Analysis}

We based our environmental effects analysis on risk assessment guidelines for other marine projects (for example, see EMEC 2005, GESAMP 2008, Nash et al. 2005). Due to the large volume of information needed to identify and characterize risks, we designed a series of 3 tables to identify:

- project actions and their potential effects on physical characteristics and biological indicators,

- possible mitigation measures to reduce or avoid effects, and

- studies that may be warranted to better understand the effects.

The primary goal of the first two tables was to determine the indicator's "overlap" in space and time with project actions that could cause an effect. For each biological indicator, the spatial and temporal exposure of the indicator to the project was determined, and the overlap of the project action's effects with the indicator's critical life stage, behavior, or resource was evaluated; this overlap is termed the "exposure". Then, the "overall risk" to the resource was determined by considering the indicator's spatial and temporal overlap (its exposure) with its physiological, biological, or behavioral characteristics that make it susceptible to the effect (Table 4). For example, harbor seals could have a medium exposure to wave energy device structures because they are a resident and abundant species in the area, but a low overall risk because they do not generally collide with or are affected by underwater structures. For each physical indicator, the spatial and temporal exposure of the indicator to the project was determined, and then the overall potential effect on the indicator was determined (Table 5). The column and row headings in the tables are intended to represent the conditions that would be encountered in any tidal or wave energy project; site-specific and technology-specific conditions would dictate the contents of the tables' cells.

Table 4 - Exposure of biological indicator to project actions

\begin{tabular}{|l|l|l|c|c|c|c|c|}
\hline $\begin{array}{l}\text { Project } \\
\text { activity }\end{array}$ & $\begin{array}{c}\text { Project } \\
\text { action }\end{array}$ & $\begin{array}{c}\text { Description of } \\
\text { action's effect } \\
\text { on indicator } \\
\text { species }\end{array}$ & $\begin{array}{c}\text { Spatial } \\
\text { exposure to } \\
\text { indicator } \\
\text { (low, med, } \\
\text { high) }\end{array}$ & $\begin{array}{c}\text { Temporal } \\
\text { exposure to } \\
\text { indicator } \\
\text { (low, med, } \\
\text { high) }\end{array}$ & $\begin{array}{c}\text { Effect's overlap } \\
\text { w/ critical life } \\
\text { stage, behavior, } \\
\text { habitat or } \\
\text { resource (low, } \\
\text { med, high) }\end{array}$ & $\begin{array}{c}\text { Overall risk } \\
\text { to indicator } \\
\text { (low, med, } \\
\text { high) }\end{array}$ & $\begin{array}{c}\text { Source(s) } \\
\text { Construction }\end{array}$ \\
\hline $\begin{array}{l}\text { As determined } \\
\text { by project site, } \\
\text { scale, and } \\
\text { location }\end{array}$ & & & & & & \\
\hline
\end{tabular}


Table 5 - Potential project effects on site physical characteristics

\begin{tabular}{|c|c|c|c|c|c|c|}
\hline Project activity & $\begin{array}{l}\text { Project } \\
\text { action }\end{array}$ & $\begin{array}{l}\text { Description of } \\
\text { action's effect on } \\
\text { site physical } \\
\text { attribute }\end{array}$ & $\begin{array}{c}\text { Spatial } \\
\text { exposure of } \\
\text { attribute (low, } \\
\text { med, high) }\end{array}$ & $\begin{array}{c}\text { Temporal } \\
\text { exposure of } \\
\text { attribute (low, } \\
\text { med, high) }\end{array}$ & $\begin{array}{l}\text { Effect's overall } \\
\text { effect on site } \\
\text { attribute (low, } \\
\text { med, high) }\end{array}$ & Source(s) \\
\hline \multicolumn{7}{|c|}{ Construction } \\
\hline \multirow{2}{*}{$\begin{array}{l}\text { As determined by } \\
\text { project site, scale, } \\
\text { and location }\end{array}$} & & & & & & \\
\hline & & & & & & \\
\hline \multicolumn{7}{|c|}{ Operation and Maintenance } \\
\hline & & & & & & \\
\hline \multicolumn{7}{|c|}{ Decommissioning } \\
\hline
\end{tabular}

This tabular effects analysis method has advantages and disadvantages. The primary advantage of this approach is its thoroughness. If detailed project and affected environment descriptions are obtained, and if effects of actions are methodically considered by filling the tables' cells, then "missing" a potential impact is unlikely. The primary disadvantage of this tabular approach is its size and relative complexity. For example, if 9 biological indicator species and habitats are selected, along with 6 site physical characteristics, then 15 detailed tables will be generated. The number of tables can be limited by selecting indicator assemblages, but a detailed effects analysis that requires many tables is commensurate with the level of analysis likely required by permitting and regulatory agencies, especially for listed species.

Effects that score medium, high, or unknown on Table 4 and Table 5 are further considered on the third type of table needed in this method, the overall risk and exposure table. In Table 6, project actions and indicators that have been screened through the criteria of Table 4 and Table 5 are further evaluated.

Table 6 - Evaluation of overall exposure and risk to indicators by project action and activity.

\begin{tabular}{|l|l|l|l|l|l|l|l|}
\hline Indicator & $\begin{array}{c}\text { Project } \\
\text { activity }\end{array}$ & $\begin{array}{c}\text { Project } \\
\text { action }\end{array}$ & $\begin{array}{c}\text { Description } \\
\text { of action's } \\
\text { effect on } \\
\text { indicator }\end{array}$ & $\begin{array}{c}\text { Overall risk } \\
\text { to indicator } \\
\text { (med, high, } \\
\text { unknown) }\end{array}$ & $\begin{array}{c}\text { Effect type } \\
\text { (in/direct, } \\
\text { beneficial, } \\
\text { neutral, } \\
\text { adverse) }\end{array}$ & $\begin{array}{c}\text { Uncertainty } \\
\text { warrants } \\
\text { further } \\
\text { study? }\end{array}$ & $\begin{array}{c}\text { Potential } \\
\text { mitigation }\end{array}$ \\
\hline & & & & & & & \\
\hline & & & & & & & \\
\hline
\end{tabular}


Table 6 is useful in two ways. First, it identifies potential mitigation measures; some effects could become negligible if these mitigations are utilized. Second, the evaluations in Table 6 identify effects that are uncertain and warrant further study. For example, noise levels that are generated by the devices are unknown, yet we know that some indicators respond to noise by avoidance and disruption of foraging and traveling. In a case like this, further studies are warranted to characterize the noise generated, and to evaluate how an indicator might respond.

\subsection{Communicate Findings}

The findings of this methodology are best presented in summary. This methodology generates numerous graphics and tables in the course of the analysis; many of these products are "working copies" and while necessary, are difficult to interpret due to their sheer numbers and sizes. Our approach in communicating findings is to present summary tables and figures, and to provide the working copies of tables and figures in appendices.

The most common communication product for work of this nature is the technical report. Sections 4 and 5 of this report are similar to what a technical report from this methodology could look like. 


\section{Environmental Effects Analysis: Wave Projects}

An environmental effects analysis was conducted on the following 2 wave energy scenarios:

- A small commercial scale, Pelamis P-2 device technology sited off Makapu'u Point, Oahu, Hawaii

- A small commercial scale, OPT Power Buoy point absorber technology sited off the coast of Humboldt County, California

The criteria for selecting these 2 of the 24 wave energy conversion scenarios included:

- Site location representative of varying environments

- Technology representing wave energy conversion

- Data readily available from technology developers

- Degree of technology development

- Degree of uncertainty in environmental effects

The latter 3 criteria in the list above did not support evaluating a large commercial scale scenario. The degree of uncertainty in technology development and environmental effects, and the lack of readily available data from large commercial scale projects, were high enough that an evaluation would have been premature.

\subsection{Summary Description of Wave Energy Technologies}

For details regarding the deployment scenarios developed for the purpose of this study, the reader is referred to report number 2 of this study, Wave Power Scenarios. The 4 wave energy conversion technologies evaluated in this report are the Pelamis Wave Power P-2 hinged contour device, the OPT Power Buoy point absorber, the Wave Dragon overtopping device, and the Aquamarine Power Oyster wave surge converter. The following table provides a summary of the four devices evaluated.

Table 7 - Devices chosen for scenario-based analysis

\begin{tabular}{|c|c|c|c|c|}
\hline Manufacturer & Deployment Water Depth & Power Take-Off & Rated Power & Mooring Type \\
\hline Pelamis Wave Power & Hydraulic & Hydraulic & $750 \mathrm{~kW}$ & Catenary \\
\hline Ocean Power Tech & Hydraulic & Hydraulic & $150 \mathrm{~kW}$ & Catenary \\
\hline Wave Dragon & Overtopping & Low head hydro & 4-7MW & Catenary \\
\hline Aquamarine Power & Water Hydraulics & Water hydraulics & $650 \mathrm{~kW}$ & Piled to Seabed \\
\hline
\end{tabular}

All of the technologies except for the Oyster device require one or more cables that transmit the electricity from the devices to shore. The cables are buried or otherwise protected from the corrosive ocean environment. Bringing the cable to shore can be accomplished by using existing infrastructure 
(example, outfalls) or by directional drilling. In directional drilling, a cable conduit is installed from the shore to the sea bottom, and the cable is snaked through the conduit.

\subsection{Project Sites}

\subsubsection{Humboldt, California}

The Humboldt coast is located in northern California, and the project site is slightly north and offshore from the harbor inlet of Humboldt Bay in Eureka, California (Figure 1). Thus, port and grid interconnections are relatively close (within 5 miles). Much could be said to describe the Humboldt coast of California, but we confine the description here to information useful and relevant to wave energy extraction. Extractable wave energy exists north of Point Conception (Wilson and Beyene 2007), and the Humboldt coast has been selected by one utility company for a wave energy test site (PG\&E 2007). The location is also conducive to wave energy development because it has a gently sloping and regular bathymetry, without canyons that could disturb the wave field, and the seabed is composed of soft sediments, suitable for burial of the subsea power cable.

There are numerous species that occur in the Humboldt coastal and marine environment that could be affected by the project, these include:

- Whales, over 20 species

- Pinnipeds, 6 species

- Elasmobranchs (sharks, skates, rays), over 15 species

- Salmon, sturgeon, rockfishes, coastal pelagic fishes, and flatfishes

- Dungeness crab

- Marine birds, over 70 species

Some of these species are listed by state and federal agencies as species of concern, threatened, or endangered. Some are important commercial species. 


\section{revision}

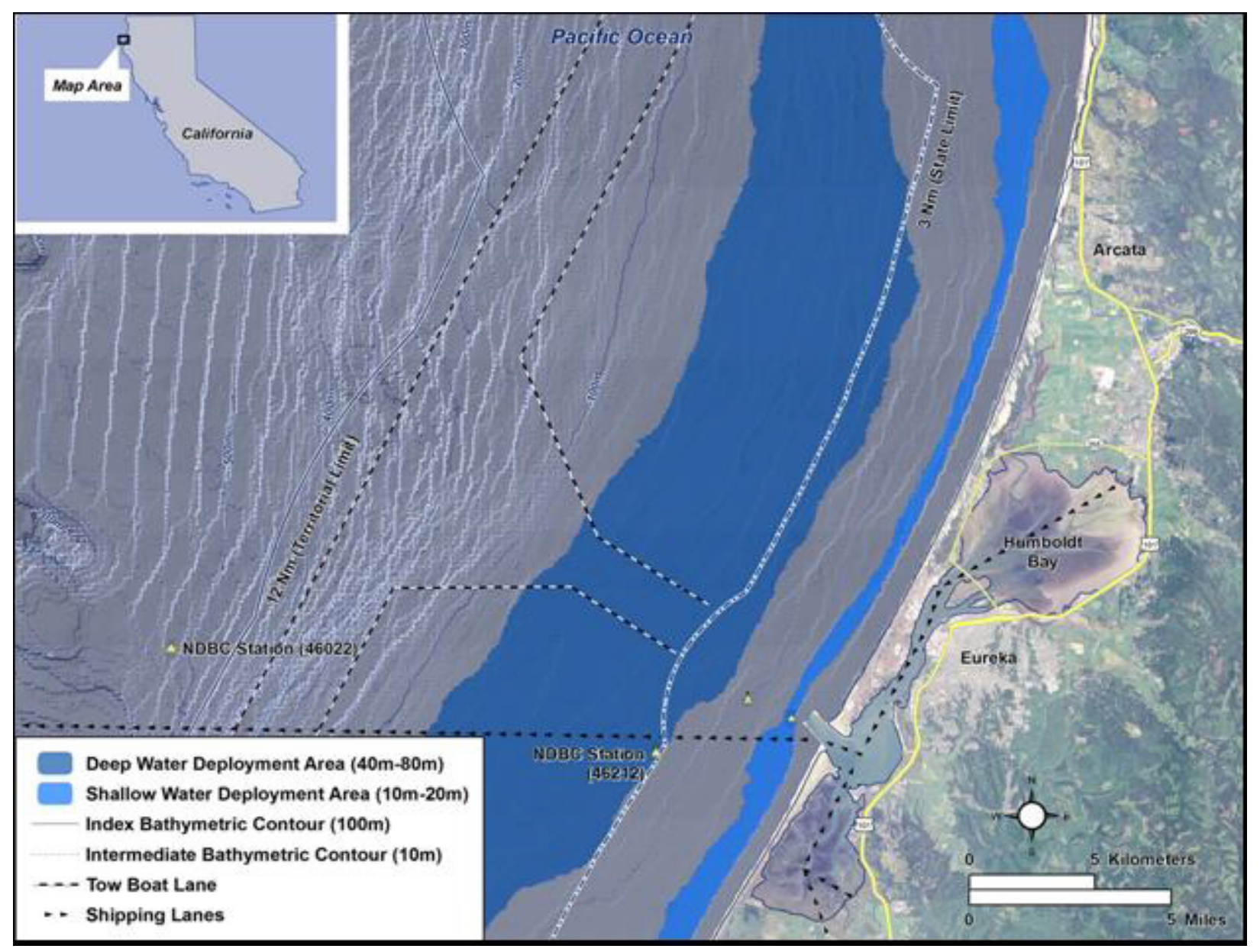

Figure 1 - Humboldt, California project site (Previsic 2009a).

\subsubsection{Makapu'u Point, Oahu, Hawaii}

Makapu'u Point is located at the eastern end of the island of Oahu, Hawaii, just north of the small islet of Manana Island (Figure 2). The seabed is composed of bedrock and limestone. Fabrication and assembly of the project devices would be performed in the Honolulu harbor, and the grid interconnection would be at the Waimanalo beach substation. There are numerous species that occur in the Makapu'u Point coastal and marine environment that could be affected by the project, these include:

- Whales, 7 species

- Pinnipeds, 1 species

- Sharks and rays, over 20 species

- Bottomfishes and pelagic fishes

- Marine birds, over 20 species 
Some of these species are listed by state and federal agencies as species of concern, threatened, or endangered. Some are important commercial species.

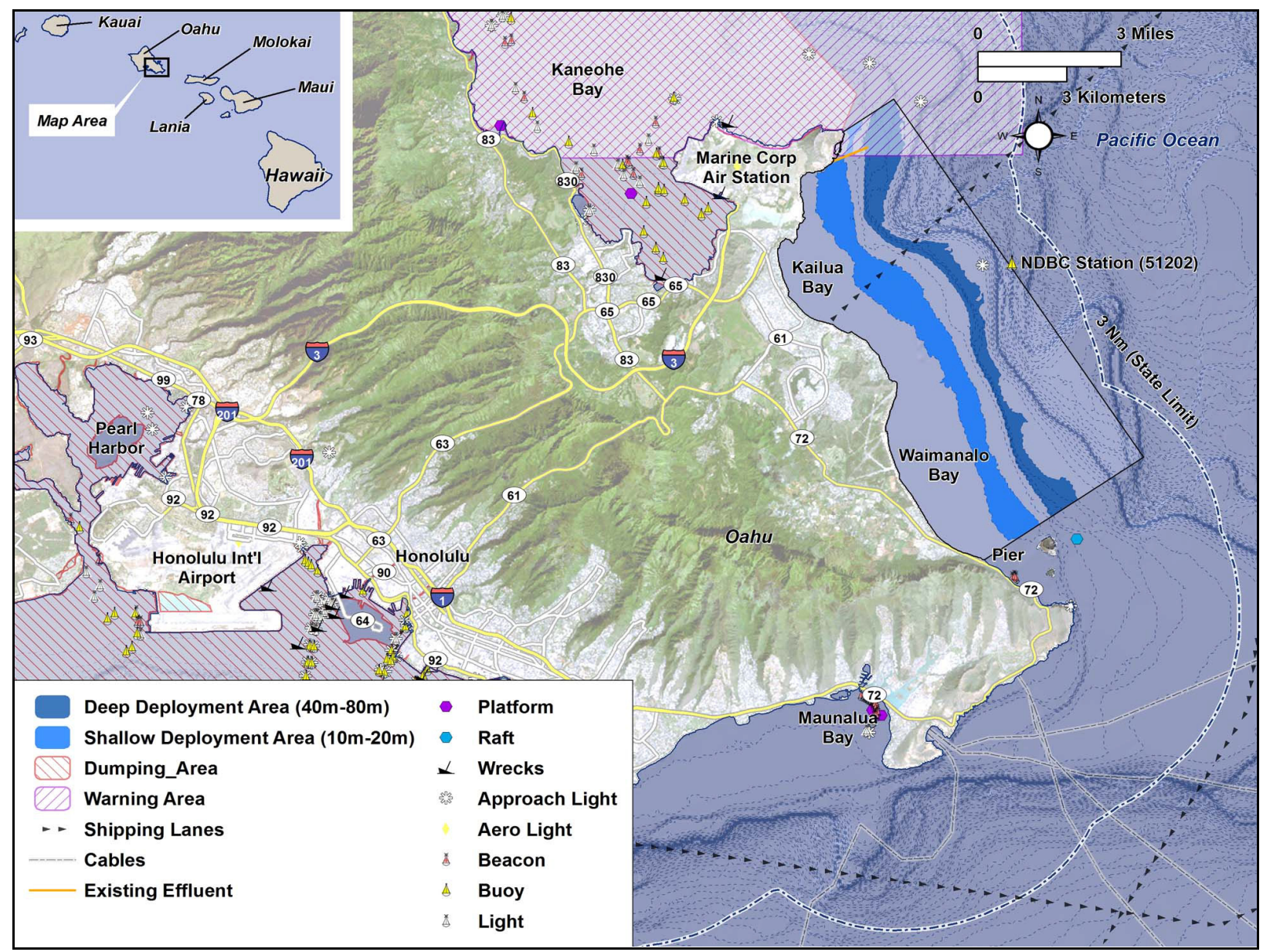

Figure 2 - Makapu'u Point, Oahu, Hawaii project site (Previsic 2009b).

\subsection{Environmental Effects Analysis: Wave Project Scenarios}

Effects on indicator species and groups, and on physical site attributes were assessed using the biological, physical, and evaluation tables (Table 4, Table 5 and Table 6 of Section 3.5). This approach generated numerous large tables, which are presented in appendices. We conducted an environmental effects analysis on the following two wave energy conversion scenarios:

1. A small commercial scale OPT Power Buoy wave project off Humboldt County, California coast

2. A small commercial scale Pelamis Wave Power P-2 project off Makapu'u Point, Oahu, Hawaii 
These two wave scenarios were selected primarily because they represent projects that could realistically be constructed in the near future.

\subsubsection{Small commercial scale OPT Power Buoy Project at Humboldt}

Details of this scenario are presented in report \#2, Wave Energy Scenarios. Table 8 shows key technical attributes and Figure 3 is an overview map showing the likely footprint of the wave farm at the deployment site.

Table 8 - Key Scenario Summary Attributes

\begin{tabular}{|c|c|}
\hline \multicolumn{2}{|l|}{ Project } \\
\hline Site & California \\
\hline Scale & Sm. Comm. \\
\hline Technology & OPT Powerbuoy \\
\hline Scenario Index & 11 \\
\hline \multicolumn{2}{|l|}{ Device } \\
\hline Rated Electrical Power & $150 \mathrm{~kW}$ \\
\hline Capacity Factor & $30 \%$ \\
\hline Average Electrical Output & $45 \mathrm{~kW}$ \\
\hline Device Type & Point Absorber \\
\hline Foundation Type & Catenary Moored \\
\hline Total Weight & 150 tons \\
\hline Device Length & $11 \mathrm{~m}$ \\
\hline Device Width & $11 \mathrm{~m}$ \\
\hline Hydraulic Fluid Volume & $2.5 m^{3}$ \\
\hline \multicolumn{2}{|l|}{ Operational Considerations } \\
\hline Installation/Decommissioning time & 1 summer \\
\hline Planned operational interventions per year & 84 \\
\hline Project life & 20 years \\
\hline \multicolumn{2}{|l|}{ Site/Array } \\
\hline Seabed composition & Sand / Mud \\
\hline Average Power density (kW/m) & $30 \mathrm{~kW} / \mathrm{m}$ \\
\hline Average Distance to shore & $6.4 \mathrm{~km}$ \\
\hline Water Depth & $70 \mathrm{~m}$ \\
\hline Array Length - km (parallel to shoreline) & 3.3 \\
\hline Array Width - km & 0.8 \\
\hline Array Surface Area $-\mathrm{km}^{\wedge} 2$ & 2.6 \\
\hline Linear Array Density & $12.2 \%$ \\
\hline Cumulative Hydraulic Fluid Volume $\left(\mathrm{m}^{\wedge} 3\right)$ & 858 \\
\hline \multicolumn{2}{|l|}{ Array Performance } \\
\hline Number of devices & 67 \\
\hline
\end{tabular}


re vision

\begin{tabular}{|l|c|}
\cline { 2 - 2 } & 3 \\
\hline Average electrical power (MW) & 10 \\
\hline Annual Energy Delivered to Grid (MWh/year) & 26,400 \\
\hline Average \# of Households & 2,319 \\
\hline Displaced CO2 (tons) & 15,840 \\
\hline
\end{tabular}

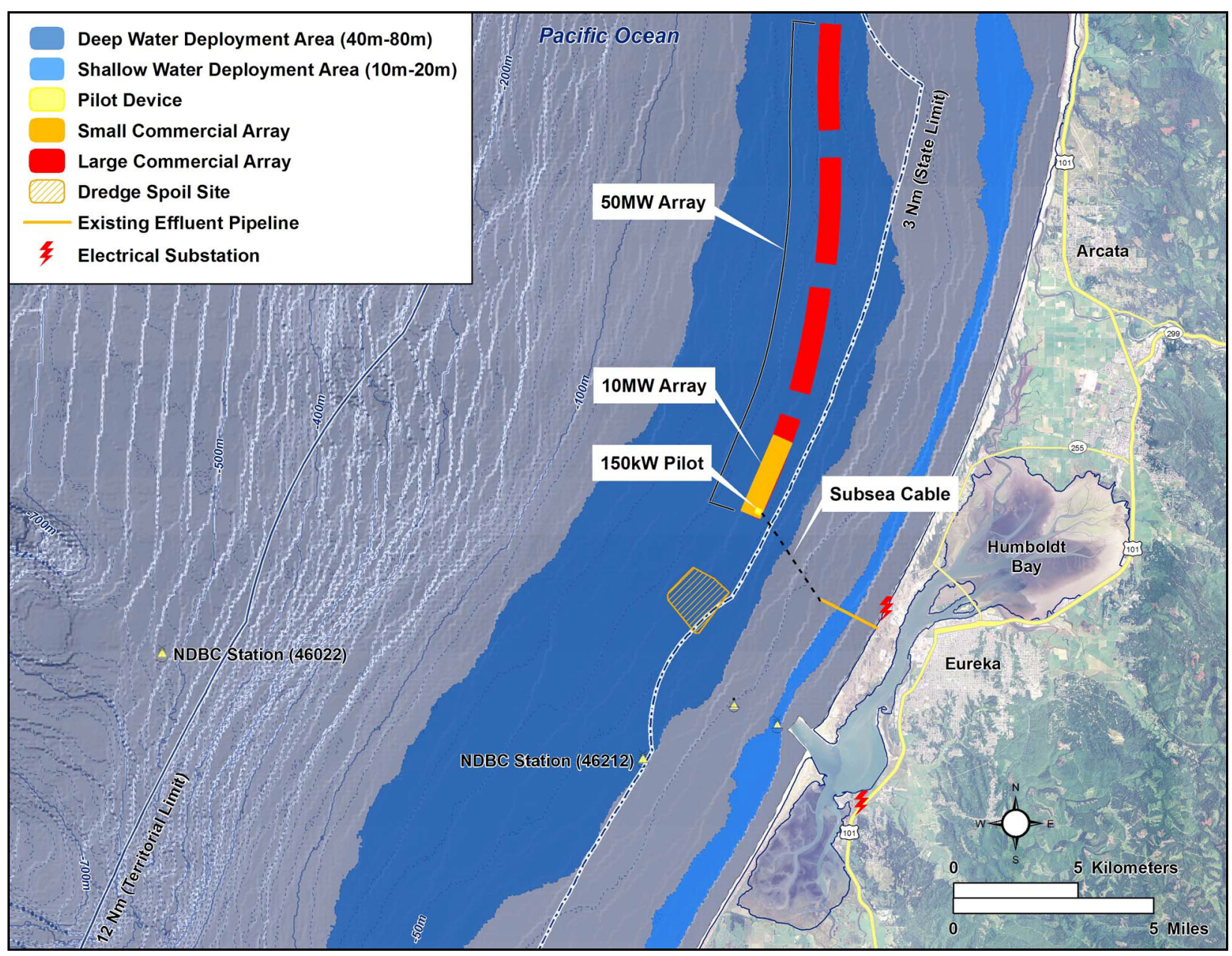

Figure 3 - OPT PowerBuoy Scenario Options (California)

\subsubsection{Potential effects of project on physical site characteristics}

Effects of the project on physical attributes, including water quality, sediment transport, and wave height are anticipated to be minimal and potentially immeasurable at the small commercial project scale. Boats used for construction and operations and maintenance may release small amounts of oils and other 
chemicals but release volumes will be extremely small under normal operating conditions ${ }^{3}$. Seabed disturbance associated with project construction, including directional drilling for laying cable, is also likely to be temporary and spatially minimal due to the sand substrate. Structures on the bottom (anchors, moorings) and on the surface are also considered to have low impacts to sediment transport and wave height due to the small scale of the project. Potential effects of project actions on physical site characteristics are detailed in Appendix D, and all effects rated with a medium, high, or unknown risk to the indicator are summarized in Table 13.

\subsubsection{Exposure of pinnipeds and cetaceans to project}

Cetacean and pinniped indicator species were selected for the Humboldt wave energy project effects analysis using the indicator selection process described in Appendix D; this approach considered the temporal distribution, habitat, abundance, and Endangered Species Act (ESA) status for the species that could occur in the project area. We grouped some species because they have similar temporal and spatial distributions and behaviors (for example, "small odontocetes"), and other times we identified a specific and representative species (for example, harbor seal). The following cetacean and pinniped species were selected as indicators: 1) humpback whale; 2) gray whale; 3) killer whale; 4) harbor porpoise; 5) small odontocetes (Pacific white-sided dolphin, Dall's porpoise, and Risso's dolphin); 6) Northern sea lion (listed as federally endangered); and 7) harbor seal. For each indicator, the spatial and temporal exposure of the indicator to the project was determined, and the overlap of the project action's potential effects with the indicator's critical life stage, behavior, or resource was evaluated; this overlap is termed "exposure." The exposure to cetacean and pinniped indicators as a result of project actions is detailed in Appendix D and summarized in Table 9.

Table 9 - Summary of exposure (medium, high or unknown) of cetacean and pinniped indicator species to a small commercial scale OPT Power Buoy wave project.

\begin{tabular}{|l|l|l|}
\hline \multicolumn{1}{|c|}{ Indicator } & \multicolumn{1}{|c|}{$\begin{array}{c}\text { Degree of } \\
\text { overlap with } \\
\text { project actions }\end{array}$} & \multicolumn{1}{c|}{ Action and potential effect } \\
\hline $\begin{array}{l}\text { Humpback whales, gray } \\
\text { whales, and harbor porpoise }\end{array}$ & Medium & $\begin{array}{l}\text { Direct impact (collision injuries) with boats associated with } \\
\text { construction, maintenance, and deconstruction activities }\end{array}$ \\
$\begin{array}{l}\text { Humpback whales, gray } \\
\text { killer whales, harbor porpoise, and }\end{array}$ & Medium & $\begin{array}{l}\text { Noise and vibration from boats, construction activities and/or } \\
\text { noise emitted from devices resulting in avoidance or masking } \\
\text { of communication and environmental cues }\end{array}$ \\
\hline
\end{tabular}

\footnotetext{
${ }^{3}$ The effects analysis methodology did not consider very low frequency but high risk conditions, such as oil spills, large earthquakes, and tsunamis. We assume that industry-accepted best management practices will be followed.
} 


\begin{tabular}{|l|l|l|}
\hline \multicolumn{1}{|c|}{ Indicator } & \multicolumn{1}{|c|}{$\begin{array}{c}\text { Degree of } \\
\text { overlap with } \\
\text { project actions }\end{array}$} & \multicolumn{1}{c|}{ Action and potential effect } \\
\hline $\begin{array}{l}\text { Gray whales that are part of } \\
\text { the Pacific Coast Feeding } \\
\text { Aggregation (PCFA) }\end{array}$ & Medium & $\begin{array}{l}\text { Toxicity from oil/chemical releases from boats, construction } \\
\text { activities, or emitted from devices }\end{array}$ \\
\hline $\begin{array}{l}\text { Gray whales that are part of } \\
\text { the PCFA, small odontocetes }\end{array}$ & Medium & $\begin{array}{l}\text { Entanglement with lost fishing gear caught on device's } \\
\text { moorings and loose cables }\end{array}$ \\
\hline $\begin{array}{l}\text { Harbor seal and Northern sea } \\
\text { lion }\end{array}$ & $\begin{array}{l}\text { High for pups, } \\
\text { medium for adults } \\
\text { lion }\end{array}$ & $\begin{array}{l}\text { Direct impact (collision injuries) with boats associated with } \\
\text { construction, maintenance, and deconstruction activities }\end{array}$ \\
\hline All & $\begin{array}{l}\text { High for pups, } \\
\text { medium for adults }\end{array}$ & $\begin{array}{l}\text { noise and vibration from boats, construction activities and/or } \\
\text { masking of communication and environmental cues }\end{array}$ \\
\hline
\end{tabular}

\subsubsection{Exposure of fish to the project}

Fish indicator species were selected for the Humboldt wave energy project effects analysis using the indicator selection process (Appendix D); this approach considered species known to occur in northern California coastal waters, with suitable habitat that either occurs in the project area or would be created by the project, and aspects of their behavior and/or biology suggest that they would be affected by the project. Fish species were also selected if the project area is located within designated Essential Fish Habitat (EFH), and/or if they are designated as federally threatened or endangered and are likely to occur in the project area.

The following indicator species groups were selected for the Humboldt wave energy project effects analysis: 1) sharks, skates, and rays; 2) flatfishes; 3) rockfishes (rockfish, cabezon, and lingcod); 4) pelagic schooling fishes (mackerel, sardine, smelts, and anchovy); 5) juvenile salmonids; 6) adult salmonids; and 7) green sturgeon. Several species of salmonids, eulachon, and green sturgeon are listed as federally threatened or endangered, and the longfin smelt is listed by the State of California as threatened. For each indicator, the spatial and temporal exposure of the indicator to the project actions was determined, and the overlap the project actions' potential effects with the indicator's critical life stage, behavior, or resource, was evaluated ("exposure"). The exposures to fish indicators as a result of project actions are detailed in Appendix D and summarized in Table 10. 
Table 10 - Summary of exposure (medium, high, unknown) of fish indicators to a small commercial scale OPT Power Buoy wave project.

\begin{tabular}{|l|l|l|}
\hline \multicolumn{1}{|c|}{ Indicator } & $\begin{array}{c}\text { Degree of } \\
\text { overlap with } \\
\text { project actions }\end{array}$ & \multicolumn{1}{c|}{ Action and potential effect } \\
\hline $\begin{array}{l}\text { Sharks and juvenile } \\
\text { salmonids }\end{array}$ & Medium & $\begin{array}{l}\text { Aggregation or behavioral changes from construction and } \\
\text { decommissioning lights, and/or navigation lights on wave devices, } \\
\text { resulting in increased vulnerability to predation on juvenile salmonids } \\
\text { by sharks or other predators }\end{array}$ \\
\hline $\begin{array}{l}\text { Sharks, skates, and } \\
\text { rays, juvenile and adult } \\
\text { salmonids, green } \\
\text { sturgeon }\end{array}$ & Unknown & Disorientation or behavioral changes from EMF \\
\hline $\begin{array}{l}\text { Rockfish, cabezon, and } \\
\text { lingcod }\end{array}$ & Medium & $\begin{array}{l}\text { Attraction to artificial reef created by structures in water column and } \\
\text { seabed resulting in changes in fish community composition }\end{array}$ \\
\hline $\begin{array}{l}\text { Flatfishes, juvenile and } \\
\text { adult salmonids, green } \\
\text { sturgeon }\end{array}$ & Unknown & $\begin{array}{l}\text { Reef effect created by structures resulting in attraction of predators, } \\
\text { changes in predator/prey interactions }\end{array}$ \\
\hline $\begin{array}{l}\text { Sharks, juvenile and } \\
\text { adult salmonids, green } \\
\text { sturgeon }\end{array}$ & Unknown & $\begin{array}{l}\text { Fish aggregation device (FAD) from structures on water's surface } \\
\text { which could attract sharks and increase predation on salmonids and } \\
\text { sturgeon; harbor seals could also haul-out on structures and attract } \\
\text { sharks and/or prey on salmonids and sturgeon }\end{array}$ \\
\hline $\begin{array}{l}\text { Rockfish, cabezon, and } \\
\text { lingcod }\end{array}$ & Medium & $\begin{array}{l}\text { Habitat loss from decommissioning devices on water's surface or } \\
\text { seabed }\end{array}$ \\
\hline
\end{tabular}

\subsubsection{Exposure of marine birds to the project}

Marine bird indicators were selected for the Humboldt wave energy project effects analysis using the indicator selection process (Appendix D); this approach considered the foraging mode, foraging habitat and diurnal rhythms of all marine bird species that could occur in the project area. The following species or species groups were selected as indicators: 1) diving ducks, loons and grebes; 2) shearwaters and storm-petrels; 3) pelicans and gulls; 4) cormorants; 5) alcids; and 6) the federally threatened marbled murrelet. The risk to marine bird indicators as a result of project actions is summarized in Table 17. For each indicator, the spatial and temporal exposure of project actions to the indicator was determined, and the overlap of the project actions' potential effects with the indicator's critical life stage, behavior, or resource was evaluated (“exposure"). The exposure to marine bird indicators as a result of project actions is detailed in Appendix D and summarized in Table 11. 
Table 11 - Summary of exposure (medium, high, unknown) of marine bird indicators to a small commercial scale OPT Power Buoy wave project.

\begin{tabular}{|c|c|c|}
\hline Indicator & $\begin{array}{l}\text { Degree of overlap } \\
\text { with project actions }\end{array}$ & Action and potential effect \\
\hline Alcids, marbled murrelet & Medium & $\begin{array}{l}\text { Attraction to and/or disorientation by construction/ } \\
\text { deconstruction lights or navigation lights on the wave } \\
\text { energy conversion devices }\end{array}$ \\
\hline $\begin{array}{l}\text { Gulls, pelicans, } \\
\text { cormorants, alcids, } \\
\text { Marbled murrelet }\end{array}$ & Medium & $\begin{array}{l}\text { Toxicity from oil/chemical releases from boats, } \\
\text { construction activities, or emitted from devices }\end{array}$ \\
\hline $\begin{array}{l}\text { Diving ducks, loons, and } \\
\text { grebes, gulls and } \\
\text { pelicans, cormorants, } \\
\text { alcids }\end{array}$ & Medium & $\begin{array}{l}\text { Attraction to aggregated prey at structures on the water's } \\
\text { surface (FAD }{ }^{4} \text { effect) which could increase predation on } \\
\text { other species (i.e., salmon), roosting on structures (for } \\
\text { gulls, pelicans, and cormorants), and/or collision with } \\
\text { devices while flying especially at night or in the fog }\end{array}$ \\
\hline $\begin{array}{l}\text { Diving ducks, loons, and } \\
\text { grebes, and cormorants }\end{array}$ & Medium & $\begin{array}{l}\text { Attraction to aggregated prey at underwater structures } \\
\text { (reef effect), entanglement with lost fishing gear or } \\
\text { underwater mooring lines, collision with underwater } \\
\text { structures }\end{array}$ \\
\hline $\begin{array}{l}\text { Diving ducks, loons, and } \\
\text { grebes }\end{array}$ & Medium & $\begin{array}{l}\text { Avoidance of area, disruption of foraging from noise } \\
\text { emitted from wave devices }\end{array}$ \\
\hline $\begin{array}{l}\text { Cormorants, alcids, } \\
\text { Marbled murrelet }\end{array}$ & Medium-High & $\begin{array}{l}\text { Avoidance of area, disruption of foraging from noise } \\
\text { emitted from boats associated with construction, } \\
\text { maintenance, and deconstruction activities }\end{array}$ \\
\hline Marbled murrelet & High & $\begin{array}{l}\text { Disruption of foraging from seabed disturbance and } \\
\text { noise and vibration associated with nearshore directional } \\
\text { drilling }\end{array}$ \\
\hline
\end{tabular}

\subsubsection{Exposure of marine invertebrates to project}

Dungeness crab was selected for the Humboldt wave energy project effects analysis because 1) it is abundant and is found in habitat directly comparable to the Humboldt wave energy project site (Pequegnat et al. 1990); 2) evidence exists for inshore/offshore migrations that would at least partially traverse Humboldt wave energy project site depths ca 70m (Pequegnat et al. 1990); 3) its importance to local commercial and recreational fisheries (Dewees et al. 2004, Hankin and Warner 2001); and 4) its importance in the pelagic food chain, in particular the diet of salmon (Brodeur et al. 2007, Hunt et al. 1999). Dungeness crab juveniles and adults are found most commonly on sand or mud bottoms from the intertidal zone to 30-m depth (Hankin and Warner 2001, Pauley et al. 1989). Their larvae (megalopae) are

\footnotetext{
${ }^{4}$ FAD is the acronym for Fish Aggregating Device.
} 
planktonic, molting into juveniles which are found in estuaries such as Humboldt Bay and in shallow, coastal waters (Gunderson et al. 1990). Juvenile and adult crabs feed opportunistically; clams, fish, amphipods and isopods are all common prey (Hankin and Warner 2001, Pauley et al. 1989). The spatial and temporal exposure of project actions to the indicator was determined, and the overlap of project actions' potential effects with the indicator's critical life stage, behavior, or resource was evaluated ("exposure"). The exposure to adult and megalopae Dungeness crab as a result of project actions is detailed in Appendix D and summarized in Table 12.

Table 12 - Summary of exposure (medium, high, unknown) of Dungeness crab to a small commercial scale OPT Power Buoy wave project.

\begin{tabular}{|l|l|l|}
\hline \multicolumn{1}{|c|}{ Indicator } & $\begin{array}{c}\text { Degree of overlap with } \\
\text { project actions }\end{array}$ & \multicolumn{1}{c|}{ Action and potential effect } \\
\hline $\begin{array}{l}\text { Dungeness crab } \\
\text { megalopae }\end{array}$ & High \\
megalopae & High & $\begin{array}{l}\text { Toxicity from oil/chemical releases from boats, construction } \\
\text { activities, or emitted from wave devices }\end{array}$ \\
\hline Dungeness crab adult & Medium & $\begin{array}{l}\text { Attraction to construction/ deconstruction lights or lights on } \\
\text { the wave devices, resulting in increased vulnerability to } \\
\text { predation }\end{array}$ \\
\hline Dungeness crab adult & Medium & $\begin{array}{l}\text { Temporary habitat loss, changes to benthic prey resources } \\
\text { from seabed disturbance associated with construction } \\
\text { activities or directional drilling }\end{array}$ \\
\hline Dungeness crab adult & Medium & $\begin{array}{l}\text { Changes in predator/prey abundance, interactions (reef } \\
\text { effect, FAD effect) from structures on surface, in water } \\
\text { column, or on seabed }\end{array}$ \\
\hline
\end{tabular}

\subsubsection{Overall risk to indicators in a small commercial scale OPT Power Buoy project at Humboldt}

Once the exposure of indicators to project actions was determined based on the overlap with spatial, temporal, and critical life stages (see previous sections and Appendix D), we assessed the overall risk of project actions to the indicators based on the potential for effects to occur. We summarized all indicators/effects that had a medium, high, or unknown risk (Table 13 and Table 14).

No project activities pose high risks to site physical characteristics (Table 13). Low risks are determined for all project activities to wave energy, sediment transport and water chemistry. Activities that may pose medium risks to site physical characteristics include:

- Boat traffic and project construction and decommissioning, which could temporarily cause noise and vibration in the acoustic environment

- Construction and decommissioning lights, which would temporarily affect the visual environment 
- Presence of device structures above the water surface that are visible from shore

- Noise emitted from the wave energy conversion devices

Project activities that may pose medium or high risks to biological indicators are (Table 14):

- Boat traffic during all project phases, resulting in collision and noise effects on some pinnipeds and cetaceans

- Construction and decommissioning of wave energy conversion devices, resulting in temporary noise effects on some pinnipeds and cetaceans

- Construction and deck lights used in construction and decommissioning, and navigation lights on wave devices, causing disorientation, collisions with vessels or devices, aggregation, and/or increased vulnerability to predation for marbled murrelets, alcids, juvenile salmonids, and sharks

- Noise and seabed disturbance from directional drilling during the construction phase in marbled murrelet nearshore foraging areas, resulting in temporary and short-term changes in food resources and disruption of foraging

Project activities that pose unknown risks to biological indicators are (Table 14):

- Surface and underwater structures could attract rockfishes, flatfishes, salmonids, and green sturgeon due to reef and fish aggregating device (FAD) effects and result in changes to predator/prey relationships, and/or species composition

- Surface structures could result in FAD effects, provide haul-out structure for pinnipeds, attract sharks, and result in increased predation on listed fish species (i.e., salmonids and green sturgeon)

- Underwater structures could become entangled with lost fishing gear and cause gray whales, small odontocetes, and/or marine birds to become entangled while diving, prey aggregation (reef effects) at structures could attract these species and increase entanglement risks, these species could also collide with underwater structures.

- Surface structures could attract species due to prey aggregations (FAD effects), and increase collision risks for diving ducks, loons, grebes, alcids

- Surface structures could provide roosting habitat, attract species due to prey aggregations (FAD effects), and increase collision risks for gulls, pelicans, and cormorants

- Navigation lights on wave energy conversion devices could attract sharks due to prey aggregations

- Generation of EMF could cause changes in orientation and behavior in sharks, skates, rays, juvenile and adult salmonids, green sturgeon, Dungeness crab, and all marine mammal indicators 


\section{re vision}

- Noise emitted from the wave energy conversion devices could alter behavior, cause avoidance, and mask environmental cues and communication signals for rockfishes, green sturgeon, humpback whales, killer whales, and small odontocetes.

We note that mitigation measures are known for most of these high and unknown effects. This study did not extend to evaluating the effectiveness of mitigation measures, and whether mitigation could reduce risk to less than significant levels was not evaluated. 
Table 13 - Overall risk (medium, high, unknown) to site physical characteristics due to a small commercial OPT Power Buoy project at the Humboldt site.

\begin{tabular}{|c|c|c|c|c|c|c|c|}
\hline Indicator & Project activity & Project action & $\begin{array}{l}\text { Description of } \\
\text { action's effect on } \\
\text { indicator species }\end{array}$ & $\begin{array}{l}\text { Overall risk to indicator } \\
\text { (med, high, unknown) }\end{array}$ & $\begin{array}{l}\text { Effect } \\
\text { type } \\
\text { (in/direct, } \\
\text { beneficial, } \\
\text { neutral, } \\
\text { adverse) } \\
\end{array}$ & $\begin{array}{l}\text { Uncertainty } \\
\text { warrants } \\
\text { further } \\
\text { study? }\end{array}$ & $\begin{array}{l}\text { Potential } \\
\text { mitigation }\end{array}$ \\
\hline \multicolumn{8}{|c|}{ Construction } \\
\hline $\begin{array}{l}\text { Acoustic } \\
\text { environment }\end{array}$ & Boat traffic & $\begin{array}{l}\text { Noise and } \\
\text { vibration }\end{array}$ & $\begin{array}{l}\text { Propellers cavitate, } \\
\text { causing pressure } \\
\text { differences }\end{array}$ & $\begin{array}{l}\text { Med, noise could be } \\
\text { elevated but short-term }\end{array}$ & $\begin{array}{l}\text { Direct, } \\
\text { adverse }\end{array}$ & $\begin{array}{l}\text { No, effects } \\
\text { reasonably } \\
\text { described }\end{array}$ & $\begin{array}{l}\text { Need for } \\
\text { mitigation not } \\
\text { established }\end{array}$ \\
\hline $\begin{array}{l}\text { Acoustic } \\
\text { environment }\end{array}$ & $\begin{array}{l}\text { Construction of } \\
\text { electrical collector } \\
\text { system, moorings, } \\
\text { foundations, and } \\
\text { device installation }\end{array}$ & $\begin{array}{l}\text { Noise and } \\
\text { vibration }\end{array}$ & $\begin{array}{l}\text { Adds to existing } \\
\text { natural and man-made } \\
\text { noise in project area }\end{array}$ & $\begin{array}{l}\text { Med, noise could be } \\
\text { elevated but short-term }\end{array}$ & $\begin{array}{l}\text { Direct, } \\
\text { adverse }\end{array}$ & $\begin{array}{l}\text { No, effects } \\
\text { reasonably } \\
\text { described }\end{array}$ & $\begin{array}{l}\text { Minimize and } \\
\text { concentrate } \\
\text { noise }\end{array}$ \\
\hline $\begin{array}{l}\text { Visual } \\
\text { environment }\end{array}$ & $\begin{array}{l}\text { Construction of } \\
\text { electrical collector } \\
\text { system, moorings, } \\
\text { foundations, and } \\
\text { device installation }\end{array}$ & $\begin{array}{l}\text { Construction } \\
\text { and deck lights }\end{array}$ & $\begin{array}{l}\text { Construction lights } \\
\text { much brighter than } \\
\text { vessel lights }\end{array}$ & $\begin{array}{l}\text { Med, lights may be visible } \\
\text { from shore, depending on } \\
\text { sea and weather condition }\end{array}$ & $\begin{array}{l}\text { Direct, } \\
\text { adverse }\end{array}$ & $\begin{array}{l}\text { No, effects } \\
\text { reasonably } \\
\text { described }\end{array}$ & $\begin{array}{l}\text { Limit } \\
\text { construction to } \\
\text { daylight hours }\end{array}$ \\
\hline \multicolumn{8}{|c|}{ Operation and Maintenance } \\
\hline $\begin{array}{l}\text { Visual } \\
\text { environment }\end{array}$ & $\begin{array}{l}\text { Structures on water's } \\
\text { surface }\end{array}$ & Structure & $\begin{array}{l}\text { Multiple devices } 8 \mathrm{~m} \\
\text { above water's surface } \\
\text { and clustered }\end{array}$ & $\begin{array}{l}\text { Med, device profiles low and } \\
\text { "facilities will probably have } \\
\text { little visual impact" (NOAA } \\
2007 \text { ) }\end{array}$ & $\begin{array}{l}\text { Direct, } \\
\text { adverse }\end{array}$ & $\begin{array}{l}\text { Yes, } \\
\text { evaluate } \\
\text { visibility } \\
\text { from shore }\end{array}$ & $\begin{array}{l}\text { Minimize device } \\
\text { profiles }\end{array}$ \\
\hline
\end{tabular}




\begin{tabular}{|c|c|c|c|c|c|c|c|}
\hline $\begin{array}{l}\text { Acoustic } \\
\text { environment }\end{array}$ & $\begin{array}{l}\text { Operation of turbines } \\
\text { or other moving parts } \\
\text { of devices }\end{array}$ & $\begin{array}{l}\text { Noise and } \\
\text { vibration }\end{array}$ & $\begin{array}{l}\text { Adds to existing } \\
\text { natural and man-made } \\
\text { noise in project area }\end{array}$ & Unknown & Unknown & $\begin{array}{l}\text { Yes, sound } \\
\text { levels } \\
\text { should be } \\
\text { determined }\end{array}$ & $\begin{array}{l}\text { Need for } \\
\text { mitigation not } \\
\text { established }\end{array}$ \\
\hline \multicolumn{8}{|c|}{ Decommissioning } \\
\hline $\begin{array}{l}\text { Acoustic } \\
\text { environment }\end{array}$ & Boat traffic & $\begin{array}{l}\text { Noise and } \\
\text { vibration }\end{array}$ & $\begin{array}{l}\text { Propellers cavitate, } \\
\text { causing pressure } \\
\text { differences }\end{array}$ & $\begin{array}{l}\text { Med, noise could be } \\
\text { elevated but short-term }\end{array}$ & $\begin{array}{l}\text { Direct, } \\
\text { adverse }\end{array}$ & $\begin{array}{l}\text { No, effects } \\
\text { reasonably } \\
\text { described }\end{array}$ & $\begin{array}{l}\text { Need for } \\
\text { mitigation not } \\
\text { established }\end{array}$ \\
\hline $\begin{array}{l}\text { Acoustic } \\
\text { environment }\end{array}$ & $\begin{array}{l}\text { Decommissioning of } \\
\text { structures on water's } \\
\text { surface or seabed }\end{array}$ & $\begin{array}{l}\text { Noise and } \\
\text { vibration }\end{array}$ & $\begin{array}{l}\text { Adds to existing } \\
\text { natural and man-made } \\
\text { noise in project area }\end{array}$ & $\begin{array}{l}\text { Med, noise could be } \\
\text { elevated but short-term }\end{array}$ & $\begin{array}{l}\text { Direct, } \\
\text { adverse }\end{array}$ & $\begin{array}{l}\text { No, effects } \\
\text { reasonably } \\
\text { described }\end{array}$ & $\begin{array}{l}\text { Need for } \\
\text { mitigation not } \\
\text { established }\end{array}$ \\
\hline $\begin{array}{l}\text { Visual } \\
\text { environment }\end{array}$ & $\begin{array}{l}\text { Decommissioning of } \\
\text { structures on water's } \\
\text { surface or seabed }\end{array}$ & $\begin{array}{l}\text { Deconstruction } \\
\text { lights }\end{array}$ & $\begin{array}{l}\text { Deconstruction lights } \\
\text { much brighter than } \\
\text { vessel lights }\end{array}$ & $\begin{array}{l}\text { Med, lights may be visible } \\
\text { from shore, depending on } \\
\text { sea and weather condition }\end{array}$ & $\begin{array}{l}\text { Direct, } \\
\text { adverse }\end{array}$ & $\begin{array}{l}\text { No, effects } \\
\text { reasonably } \\
\text { described }\end{array}$ & $\begin{array}{l}\text { Limit } \\
\text { deconstruction } \\
\text { to daylight } \\
\text { hours }\end{array}$ \\
\hline
\end{tabular}

Table 14 - Overall risk (medium, high, unknown) to indicator species or species groups due to a small commercial OPT Power Buoy project at the Humboldt site.

\begin{tabular}{|c|c|c|c|c|c|c|c|}
\hline Indicator & Project activity & $\begin{array}{l}\text { Project } \\
\text { action }\end{array}$ & $\begin{array}{l}\text { Description of action's } \\
\text { effect on indicator } \\
\text { species }\end{array}$ & $\begin{array}{l}\text { Overall risk to } \\
\text { indicator } \\
\text { (med, high, } \\
\text { unknown) }\end{array}$ & $\begin{array}{l}\text { Effect type } \\
\text { (in/direct, } \\
\text { beneficial, } \\
\text { neutral, } \\
\text { adverse) }\end{array}$ & $\begin{array}{l}\text { Uncertainty } \\
\text { warrants } \\
\text { further study? }\end{array}$ & $\begin{array}{l}\text { Potential } \\
\text { mitigation }\end{array}$ \\
\hline \multicolumn{8}{|c|}{ Construction } \\
\hline $\begin{array}{l}\text { Humpback } \\
\text { whales, gray } \\
\text { whales, Northern } \\
\text { sea lion }\end{array}$ & Boat traffic & $\begin{array}{l}\text { Direct } \\
\text { impact }\end{array}$ & Collision injuries & Med-High & $\begin{array}{l}\text { Direct and } \\
\text { adverse }\end{array}$ & $\begin{array}{l}\text { No, effects } \\
\text { reasonably } \\
\text { described }\end{array}$ & $\begin{array}{l}\text { Vessel speed } \\
\text { limits }\end{array}$ \\
\hline $\begin{array}{l}\text { Humpback } \\
\text { whales, gray } \\
\text { whales, harbor } \\
\text { porpoise }\end{array}$ & Boat traffic & $\begin{array}{l}\text { Noise and } \\
\text { vibration }\end{array}$ & $\begin{array}{l}\text { Avoidance, masking of } \\
\text { environmental cues, } \\
\text { communication signals }\end{array}$ & Med-High & $\begin{array}{l}\text { Direct and } \\
\text { adverse }\end{array}$ & $\begin{array}{l}\text { No, effects } \\
\text { reasonably } \\
\text { described }\end{array}$ & $\begin{array}{l}\text { Vessel speed } \\
\text { limits }\end{array}$ \\
\hline
\end{tabular}




\begin{tabular}{|c|c|c|c|c|c|c|c|}
\hline Marbled murrelets & $\begin{array}{l}\text { Directional drilling, } \\
\text { and laying cable } \\
\text { under/on seabed }\end{array}$ & $\begin{array}{l}\text { Seabed } \\
\text { disturbance }\end{array}$ & $\begin{array}{l}\text { Possible short-term } \\
\text { changes in food } \\
\text { resources }\end{array}$ & Med & $\begin{array}{l}\text { Indirect and } \\
\text { adverse }\end{array}$ & $\begin{array}{l}\text { No, effects } \\
\text { reasonably } \\
\text { described }\end{array}$ & $\begin{array}{l}\text { Drill in non- } \\
\text { nesting season } \\
\text { (Oct-April) }\end{array}$ \\
\hline $\begin{array}{l}\text { Marbled murrelets, } \\
\text { gray whales }\end{array}$ & $\begin{array}{l}\text { Directional drilling, } \\
\text { and laying cable } \\
\text { under/on seabed }\end{array}$ & $\begin{array}{l}\text { Noise and } \\
\text { vibration }\end{array}$ & $\begin{array}{l}\text { Possible movement } \\
\text { away from area and } \\
\text { disruption of foraging }\end{array}$ & Med & $\begin{array}{l}\text { Direct and } \\
\text { adverse }\end{array}$ & $\begin{array}{l}\text { No, effects } \\
\text { reasonably } \\
\text { described }\end{array}$ & $\begin{array}{l}\text { Drill in non- } \\
\text { nesting season } \\
\text { (Oct-April) }\end{array}$ \\
\hline $\begin{array}{l}\text { Humpback } \\
\text { whales, gray } \\
\text { whales, harbor } \\
\text { porpoise }\end{array}$ & $\begin{array}{l}\text { Construction of } \\
\text { electrical collector } \\
\text { system, moorings } \\
\text { and foundations, } \\
\text { and device } \\
\text { installation }\end{array}$ & $\begin{array}{l}\text { Noise and } \\
\text { vibration }\end{array}$ & $\begin{array}{l}\text { Avoidance, masking of } \\
\text { environmental cues, } \\
\text { communication signals }\end{array}$ & Med-High & $\begin{array}{l}\text { Direct and } \\
\text { adverse }\end{array}$ & $\begin{array}{l}\text { No, effects } \\
\text { reasonably } \\
\text { described }\end{array}$ & $\begin{array}{l}\text { Vessel speed } \\
\text { limits }\end{array}$ \\
\hline $\begin{array}{l}\text { Juvenile } \\
\text { salmonids }\end{array}$ & $\begin{array}{l}\text { Construction of } \\
\text { electrical collector } \\
\text { system, moorings } \\
\text { and foundations, } \\
\text { and device } \\
\text { installation }\end{array}$ & $\begin{array}{l}\text { Construction } \\
\text { \& deck lights }\end{array}$ & $\begin{array}{l}\text { Behavioral changes, } \\
\text { more vulnerable to } \\
\text { predation }\end{array}$ & Med & $\begin{array}{l}\text { Direct and } \\
\text { adverse }\end{array}$ & $\begin{array}{l}\text { No, effects } \\
\text { reasonably } \\
\text { described }\end{array}$ & $\begin{array}{l}\text { Limit } \\
\text { construction to } \\
\text { daylight hours }\end{array}$ \\
\hline \multicolumn{8}{|c|}{ Operation and Maintenance } \\
\hline $\begin{array}{l}\text { Humpback } \\
\text { whales, gray } \\
\text { whales }\end{array}$ & Boat traffic & $\begin{array}{l}\text { Noise and } \\
\text { vibration }\end{array}$ & $\begin{array}{l}\text { Avoidance, masking of } \\
\text { environmental cues, } \\
\text { communication signals }\end{array}$ & Med-High & $\begin{array}{l}\text { Direct and } \\
\text { adverse }\end{array}$ & $\begin{array}{l}\text { No, effects } \\
\text { reasonably } \\
\text { described }\end{array}$ & $\begin{array}{l}\text { Vessel speed } \\
\text { limits }\end{array}$ \\
\hline $\begin{array}{l}\text { Humpback } \\
\text { whales, gray } \\
\text { whales, Northern } \\
\text { sea lion }\end{array}$ & Boat traffic & $\begin{array}{l}\text { Direct } \\
\text { impact }\end{array}$ & Collision injuries & Med-High & $\begin{array}{l}\text { Direct and } \\
\text { adverse }\end{array}$ & $\begin{array}{l}\text { No, effects } \\
\text { reasonably } \\
\text { described }\end{array}$ & $\begin{array}{l}\text { Vessel speed } \\
\text { limits }\end{array}$ \\
\hline $\begin{array}{l}\text { Diving ducks, } \\
\text { loons, grebes, } \\
\text { cormorants, alcids, } \\
\text { gray whales, small } \\
\text { odontocetes }\end{array}$ & $\begin{array}{l}\text { Structures in water } \\
\text { column and on } \\
\text { seabed, such as } \\
\text { devices and } \\
\text { moorings and } \\
\text { footings }\end{array}$ & Structure & $\begin{array}{l}\text { Possible attraction to } \\
\text { increased prey (reef } \\
\text { effect), entanglement } \\
\text { with lost fishing gear/ } \\
\text { moorings, collisions with } \\
\text { structures while diving }\end{array}$ & Unknown & $\begin{array}{l}\text { Direct and } \\
\text { indirect, } \\
\text { beneficial and } \\
\text { adverse }\end{array}$ & $\begin{array}{l}\text { Yes, use of } \\
\text { structures } \\
\text { could be } \\
\text { measured }\end{array}$ & $\begin{array}{l}\text { Remove tangled } \\
\text { gear periodically, } \\
\text { antifouling paint }\end{array}$ \\
\hline $\begin{array}{l}\text { Rockfishes, } \\
\text { lingcod, cabezon }\end{array}$ & $\begin{array}{l}\text { Structures in water } \\
\text { column and on } \\
\text { seabed, such as } \\
\text { devices and } \\
\text { moorings and } \\
\text { footings }\end{array}$ & Structure & $\begin{array}{l}\text { Attraction to artificial } \\
\text { reef, changes in fish } \\
\text { community }\end{array}$ & Med & $\begin{array}{l}\text { Indirect and } \\
\text { beneficial? }\end{array}$ & $\begin{array}{l}\text { Yes, use of } \\
\text { structures } \\
\text { could be } \\
\text { measured }\end{array}$ & None needed? \\
\hline
\end{tabular}




\begin{tabular}{|c|c|c|c|c|c|c|c|}
\hline $\begin{array}{l}\text { Flatfishes, juvenile } \\
\text { salmonids, adult } \\
\text { salmonids, green } \\
\text { sturgeon }\end{array}$ & $\begin{array}{l}\text { Structures in water } \\
\text { column and on } \\
\text { seabed, such as } \\
\text { devices and } \\
\text { moorings and } \\
\text { footings }\end{array}$ & Structure & $\begin{array}{l}\text { Possible reef effect, } \\
\text { attraction of predators } \\
\text { (e.g., rockfish), changes } \\
\text { in predator/prey } \\
\text { interactions }\end{array}$ & Unknown & $\begin{array}{l}\text { Indirect and } \\
\text { adverse }\end{array}$ & $\begin{array}{l}\text { Yes, use of } \\
\text { structures } \\
\text { could be } \\
\text { measured }\end{array}$ & $?$ \\
\hline $\begin{array}{l}\text { Diving ducks, } \\
\text { loons, grebes, } \\
\text { gulls and pelicans, } \\
\text { cormorants, alcids }\end{array}$ & $\begin{array}{l}\text { Structures on } \\
\text { water's surface }\end{array}$ & Structure & $\begin{array}{l}\text { Possible roosting } \\
\text { habitat, attraction to } \\
\text { increased prey (FAD } \\
\text { effect) which could } \\
\text { increase predation on } \\
\text { other species (i.e., } \\
\text { salmon), collision while } \\
\text { flying }\end{array}$ & Unknown & $\begin{array}{l}\text { Direct and } \\
\text { indirect, } \\
\text { beneficial and } \\
\text { adverse }\end{array}$ & $\begin{array}{l}\text { Yes, flight } \\
\text { paths, heights, } \\
\text { use of area, } \\
\text { and collision } \\
\text { rates could be } \\
\text { measured }\end{array}$ & $\begin{array}{l}\text { Minimize height } \\
\text { of structure } \\
\text { above water's } \\
\text { surface, design } \\
\text { devices to } \\
\text { prevent roosting }\end{array}$ \\
\hline Sharks & $\begin{array}{l}\text { Structures on } \\
\text { water's surface }\end{array}$ & Structure & $\begin{array}{l}\text { Possible FAD effect, } \\
\text { could provide haul-out } \\
\text { structure for pinnipeds, } \\
\text { which could also attract } \\
\text { sharks and increase } \\
\text { predation on other } \\
\text { species (i.e., salmon) }\end{array}$ & Unknown & $\begin{array}{l}\text { Indirect and } \\
\text { beneficial }\end{array}$ & $\begin{array}{l}\text { No, effects } \\
\text { reasonably } \\
\text { described }\end{array}$ & $\begin{array}{l}\text { Design } \\
\text { structures to } \\
\text { prevent haul-out } \\
\text { by pinnipeds }\end{array}$ \\
\hline Northern sea lion & $\begin{array}{l}\text { Structures on } \\
\text { water's surface }\end{array}$ & Structure & $\begin{array}{l}\text { Likely to provide haul } \\
\text { out structure; may } \\
\text { attract sea lions and } \\
\text { increase potential for } \\
\text { other impacts }\end{array}$ & Med & $\begin{array}{l}\text { Direct and } \\
\text { indirect, } \\
\text { adverse and } \\
\text { beneficial }\end{array}$ & $\begin{array}{l}\text { No, effects } \\
\text { reasonably } \\
\text { described }\end{array}$ & $\begin{array}{l}\text { Design } \\
\text { structures to } \\
\text { prevent haul-out } \\
\text { by pinnipeds }\end{array}$ \\
\hline $\begin{array}{l}\text { Juvenile } \\
\text { salmonids, adult } \\
\text { salmonids, green } \\
\text { sturgeon }\end{array}$ & $\begin{array}{l}\text { Structures on } \\
\text { water's surface }\end{array}$ & Structure & $\begin{array}{l}\text { Possible FAD effect, } \\
\text { attraction of predators } \\
\text { (e.g., sharks, pinnipeds) }\end{array}$ & Unknown & $\begin{array}{l}\text { Indirect and } \\
\text { adverse }\end{array}$ & $\begin{array}{l}\text { No, effects } \\
\text { reasonably } \\
\text { described }\end{array}$ & $\begin{array}{l}\text { Design } \\
\text { structures to } \\
\text { prevent haul-out } \\
\text { by pinnipeds }\end{array}$ \\
\hline Sharks & $\begin{array}{l}\text { Structures on } \\
\text { water's surface }\end{array}$ & $\begin{array}{l}\text { Navigation } \\
\text { lights }\end{array}$ & $\begin{array}{l}\text { Sharks may be } \\
\text { attracted to lights due to } \\
\text { prey aggregation }\end{array}$ & Unknown & $\begin{array}{l}\text { Direct and } \\
\text { beneficial }\end{array}$ & $\begin{array}{l}\text { No, effects } \\
\text { reasonably } \\
\text { described }\end{array}$ & $\begin{array}{l}\text { Minimize and } \\
\text { shield lighting }\end{array}$ \\
\hline $\begin{array}{l}\text { Juvenile } \\
\text { salmonids }\end{array}$ & $\begin{array}{l}\text { Structures on } \\
\text { water's surface }\end{array}$ & $\begin{array}{l}\text { Navigation } \\
\text { lights }\end{array}$ & $\begin{array}{l}\text { Behavioral changes, } \\
\text { more vulnerable to } \\
\text { predation (e.g., sharks }\end{array}$ & Med & $\begin{array}{l}\text { Indirect and } \\
\text { adverse }\end{array}$ & $\begin{array}{l}\text { No, effects } \\
\text { reasonably } \\
\text { described }\end{array}$ & $\begin{array}{l}\text { Minimize and } \\
\text { shield lighting }\end{array}$ \\
\hline $\begin{array}{l}\text { Sharks, skates, } \\
\text { rays, juvenile and } \\
\text { adult salmonids, } \\
\text { green sturgeon, } \\
\text { Dungeness crab, } \\
\text { all marine } \\
\text { mammal indicators } \\
\end{array}$ & $\begin{array}{l}\text { Electricity } \\
\text { conduction through } \\
\text { cable }\end{array}$ & EMF & $\begin{array}{l}\text { Possible changes in } \\
\text { orientation, behavior }\end{array}$ & Unknown & $\begin{array}{l}\text { Unknown if } \\
\text { effect occurs }\end{array}$ & $\begin{array}{l}\text { Yes, effects } \\
\text { literature is } \\
\text { growing but no } \\
\text { consensus yet }\end{array}$ & $\begin{array}{l}\text { Shielding, } \\
\text { "Faraday cages", } \\
\text { bury high-voltage } \\
\text { DC cables to } \\
\text { reduce EMF } \\
\text { (EAO British } \\
\text { Columbia 2009) }\end{array}$ \\
\hline
\end{tabular}


revision

\begin{tabular}{|c|c|c|c|c|c|c|c|}
\hline $\begin{array}{l}\text { Rockfishes, } \\
\text { lingcod, cabezon, } \\
\text { green sturgeon, } \\
\text { humpback whales, } \\
\text { killer whales, small } \\
\text { odontocetes }\end{array}$ & $\begin{array}{l}\text { Operation of } \\
\text { turbines or other } \\
\text { moving parts of } \\
\text { devices }\end{array}$ & $\begin{array}{l}\text { Noise and } \\
\text { vibration }\end{array}$ & $\begin{array}{l}\text { Possible altered } \\
\text { behavior, avoidance, } \\
\text { masking of } \\
\text { environmental cues, } \\
\text { communication signals }\end{array}$ & $\begin{array}{l}\text { Med for } \\
\text { whales, } \\
\text { Unknown for } \\
\text { small } \\
\text { odontocetes } \\
\text { and fishes }\end{array}$ & $\begin{array}{l}\text { Direct and } \\
\text { adverse }\end{array}$ & $\begin{array}{l}\text { Yes, device } \\
\text { noise should } \\
\text { be measured, } \\
\text { compared to } \\
\text { noise effect } \\
\text { thresholds in } \\
\text { literature }\end{array}$ & $\begin{array}{l}\text { Need for } \\
\text { mitigation not } \\
\text { established, ? }\end{array}$ \\
\hline \multicolumn{8}{|c|}{ Decommissioning } \\
\hline $\begin{array}{l}\text { Humpback } \\
\text { whales, Northern } \\
\text { sea lion, gray } \\
\text { whales }\end{array}$ & Boat traffic & $\begin{array}{l}\text { Direct } \\
\text { impact }\end{array}$ & Collision injuries & Med-High & $\begin{array}{l}\text { Direct and } \\
\text { adverse }\end{array}$ & $\begin{array}{l}\text { No, effects } \\
\text { reasonably } \\
\text { described }\end{array}$ & $\begin{array}{l}\text { Vessel speed } \\
\text { limits }\end{array}$ \\
\hline $\begin{array}{l}\text { Humpback } \\
\text { whales, gray } \\
\text { whales, harbor } \\
\text { porpoise }\end{array}$ & Boat traffic & $\begin{array}{l}\text { Noise and } \\
\text { vibration }\end{array}$ & $\begin{array}{l}\text { Avoidance, masking of } \\
\text { environmental cues, } \\
\text { communication signals }\end{array}$ & Med-High & $\begin{array}{l}\text { Direct and } \\
\text { adverse }\end{array}$ & $\begin{array}{l}\text { No, effects } \\
\text { reasonably } \\
\text { described }\end{array}$ & $\begin{array}{l}\text { Vessel speed } \\
\text { limits }\end{array}$ \\
\hline $\begin{array}{l}\text { Rockfishes, } \\
\text { lingcod, cabezon }\end{array}$ & $\begin{array}{l}\text { Decommissioning } \\
\text { of structures on } \\
\text { water's surface or } \\
\text { seabed }\end{array}$ & $\begin{array}{l}\text { Seabed } \\
\text { disturbance }\end{array}$ & $\begin{array}{l}\text { Habitat loss, changes in } \\
\text { prey resources }\end{array}$ & Med & $\begin{array}{l}\text { Direct and } \\
\text { adverse }\end{array}$ & $?$ & $\begin{array}{l}\text { Need for } \\
\text { mitigation not } \\
\text { established }\end{array}$ \\
\hline $\begin{array}{l}\text { Humpback } \\
\text { whales, gray } \\
\text { whales }\end{array}$ & $\begin{array}{l}\text { Decommissioning } \\
\text { of structures on } \\
\text { water's surface or } \\
\text { seabed }\end{array}$ & $\begin{array}{l}\text { Noise and } \\
\text { vibration }\end{array}$ & $\begin{array}{l}\text { Avoidance, masking of } \\
\text { environmental cues, } \\
\text { communication signals }\end{array}$ & Med-High & $\begin{array}{l}\text { Direct and } \\
\text { adverse }\end{array}$ & $\begin{array}{l}\text { No, effects } \\
\text { reasonably } \\
\text { described }\end{array}$ & $\begin{array}{l}\text { Vessel speed } \\
\text { limits }\end{array}$ \\
\hline
\end{tabular}




\subsubsection{Priority studies warranted for a small commercial OPT Power Buoy project at Humboldt}

Our final analysis was to identify potential effects that are sufficiently high and uncertain to warrant further study (Table 15); we compiled and summarized possible future studies from the overall risk evaluation table.

Table 15 - Possible future studies warranted for a small commercial scale OPT Power Buoys at Humboldt site

\begin{tabular}{|c|c|c|}
\hline Indicator species or group & Potential Effect & Possible future studies \\
\hline $\begin{array}{l}\text { Diving ducks, loons, grebes, } \\
\text { cormorants, alcids, small } \\
\text { odontocetes }\end{array}$ & $\begin{array}{l}\text { Attraction to increased prey (reef effect), } \\
\text { entanglement with lost fishing gear/ } \\
\text { moorings while diving, collisions with } \\
\text { underwater structures }\end{array}$ & $\begin{array}{l}\text { Use of structures could be } \\
\text { evaluated }\end{array}$ \\
\hline Rockfishes, lingcod, cabezon & $\begin{array}{l}\text { Attraction to artificial reef, changes in fish } \\
\text { community }\end{array}$ & $\begin{array}{l}\text { Use of structures could be } \\
\text { evaluated }\end{array}$ \\
\hline $\begin{array}{l}\text { Flatfishes, juvenile salmonids, } \\
\text { adult salmonids, green sturgeon }\end{array}$ & $\begin{array}{l}\text { Reef effect, attraction of predators (e.g., } \\
\text { rockfish), changes in predator/prey } \\
\text { interactions }\end{array}$ & $\begin{array}{l}\text { Use of structures could be } \\
\text { evaluated }\end{array}$ \\
\hline $\begin{array}{l}\text { Diving ducks, loons, grebes, } \\
\text { alcids }\end{array}$ & $\begin{array}{l}\text { Attraction to increased prey (FAD effect) } \\
\text { which could increase predation on other } \\
\text { species (i.e., salmon), collision with } \\
\text { surface structures while flying }\end{array}$ & $\begin{array}{l}\text { Flight paths, heights, use of area, } \\
\text { and collision rates could be } \\
\text { evaluated }\end{array}$ \\
\hline Gulls and pelicans, cormorants & $\begin{array}{l}\text { Roosting habitat, attraction to increased } \\
\text { prey (FAD effect) which could increase } \\
\text { predation on other species (i.e., salmon), } \\
\text { collision with surface structures while } \\
\text { flying }\end{array}$ & $\begin{array}{l}\text { Flight paths, heights, use of area, } \\
\text { and collision rates could be } \\
\text { evaluated }\end{array}$ \\
\hline $\begin{array}{l}\text { Sharks, skates, rays, juvenile and } \\
\text { adult salmonids, green sturgeon, } \\
\text { Dungeness crab, all marine } \\
\text { mammal indicators }\end{array}$ & $\begin{array}{l}\text { Changes in orientation, behavior due to } \\
\text { EMF }\end{array}$ & $\begin{array}{l}\text { Effects literature is growing but } \\
\text { no consensus yet }\end{array}$ \\
\hline $\begin{array}{l}\text { Rockfishes, lingcod, cabezon, } \\
\text { green sturgeon, humpback } \\
\text { whales, killer whales, small } \\
\text { odontocetes }\end{array}$ & $\begin{array}{l}\text { Altered behavior, avoidance, masking of } \\
\text { environmental cues, communication } \\
\text { signals due to noise and vibration of } \\
\text { devices }\end{array}$ & $\begin{array}{l}\text { Device noise should be } \\
\text { measured and compared to } \\
\text { noise effect thresholds in the } \\
\text { literature }\end{array}$ \\
\hline
\end{tabular}

\subsubsection{Application of a small commercial scale OPT Power Buoy wave project to other Humboldt scenarios}

The combination of 4 wave energy technologies and 3 project scales results in 12 Humboldt scenarios. The detailed effects analysis was applied to installation, operations and maintenance, and 
decommissioning of a small commercial OPT Power Buoys project. We can extrapolate the risks identified in Scenario 11 to the other scenarios by considering the similarities and differences in technologies, and in project scale.

Boat traffic was identified as a project activity that posed high risk and exposure to some species of cetaceans and pinnipeds in a small commercial scale OPT Power Buoy wave project. Risk and exposure due to boat traffic would be directly proportional to project scale; for pilot scale Pelamis and Power Buoy projects risks would be lower. The Wave Dragon is a single large device, rather than many smaller ones, boat traffic would likely be less compared to a small commercial scale OPT Power Buoy wave project. For all large commercial scale projects we assume that boat traffic effects will be greater than those identified in a small commercial scale OPT Power Buoy wave project. The Oyster technology, regardless of scale, may pose less boat traffic risk due to its location nearer to shore.

Construction and decommissioning activities were identified as posing high risk and exposure of noise to some cetaceans and pinnipeds in a small commercial scale OPT Power Buoy wave project. Like boat traffic, these risks are also directly proportional to project scale, and with our current level of knowledge, we cannot assess whether some technologies will allow significantly less construction or decommissioning noise than that anticipated in a small commercial scale OPT Power Buoy wave project.

For the small commercial scale OPT Power Buoy wave project, we determined that artificial reef and FAD effects could change predator and prey relationships, and increase exposure to lost gear entanglement; these effects may vary depending on technology. Entanglement with debris and/or lost fishing gear is well documented and varies by location (NOAA 2009a, NOAA 2009b, NOAA 2009c). Risk of marine mammal entanglement with the project or lost gear that entangles with project moorings is likely to increase with larger project scales.

For example, the Wave Dragon technology may have a greater FAD effect due to its configuration as a larger unit given the same energy output. The Wave Dragon may present differences in effects due to moorings; it may require less structure in the water column than the Pelamis or Power Buoy technologies, presenting fewer artificial reef effects. The Oyster technology, due to its lack of surface structure, would be expected to cause minimal, if any, FAD effects.

For the small commercial scale OPT Power Buoy wave project, we determined that EMF effects remain unknown despite a growing literature. EMF effects would also be project scale dependent, similar to boat 
traffic and noise effects discussed above. However, the Oyster technology is notable because it would produce no EMF in the marine environment.

The noise characteristics produced by the devices are unknown, but likely varies among all of the technologies. Amplitude and frequency of noise emitted by devices could vary significantly by technology and scale; a device's amplitude determines the noise propagation, or how far the sound travels, and its frequency determines the marine mammal species that can detect or are affected by the noise. At this time, we have no basis for assessing the noise characteristics among technologies, or for comparing the effects of the noise produced by different types of devices or at different scales on marine mammals.

Effects to the physical environment, including water quality, sediment transport, and wave energy are scale-dependent. However, because the Oyster and Wave Dragon technologies do not use hydraulic fluids, they presents no potential effect to water quality associated with hydraulic fluid seepage or spills. The inshore deployment of the Oyster technology is likely to have greater effects on wave energy dynamics, particularly at the commercial scale.

\subsubsection{Small commercial scale Pelamis Wave Power P-2 project at Makapu'u}

Details of this scenario are presented in report \#2, Wave Power Scenarios. Table 16 shows key technical attributes and Figure 4 is an overview map showing the likely footprint of the wave farm at the deployment site.

Table 16 - Summary table of small commercial Pelamis array deployed at Waimanalo Bay in Hawaii

\begin{tabular}{|l|c|}
\hline Project & Hawaii \\
\hline Site & Sm. Comm. \\
\hline Scale & Pelamis \\
\hline Technology & \\
\hline Scenario Index & $517 \mathrm{~kW}$ \\
\hline Device & $30 \%$ \\
\hline Rated Electrical Power & $155 \mathrm{~kW}$ \\
\hline Capacity Factor & Attenuator / Line Absorber \\
\hline Average Electrical Output & Catenary Moored \\
\hline Device Type & 700 tons \\
\hline Foundation Type & $180 \mathrm{~m}$ \\
\hline Total Weight & \\
\hline Device Length & \\
\hline
\end{tabular}




\begin{tabular}{|c|c|c|c|}
\hline Device Width & \multicolumn{3}{|c|}{$6 m$} \\
\hline Hydraulic Fluid Volume & \multicolumn{3}{|c|}{$12.8 \mathrm{~m}^{\wedge} 3$} \\
\hline \multicolumn{4}{|l|}{ Operational Considerations } \\
\hline Installation/Decommissioning time & \multicolumn{3}{|c|}{1 summer } \\
\hline Planned operational interventions per year & \multicolumn{3}{|c|}{25} \\
\hline Project life & \multicolumn{3}{|c|}{20 years } \\
\hline \multicolumn{4}{|l|}{ Site/Array } \\
\hline Seabed composition & \multicolumn{3}{|c|}{ Sand / Limestone } \\
\hline Average Power density (kW/m) & \multicolumn{3}{|c|}{$14 \mathrm{~kW} / \mathrm{m}$} \\
\hline Average Distance to shore & \multicolumn{3}{|c|}{$3.2 \mathrm{~km}$} \\
\hline Water Depth & \multicolumn{3}{|c|}{$50 \mathrm{~m}$} \\
\hline \multirow[t]{2}{*}{ Array Length - km (parallel to shoreline) } & \multicolumn{3}{|c|}{2.5} \\
\hline & Pilot & 100-MW array & 200-MW array \\
\hline Array Width - km & 0.35 & 0.5 & 0.5 \\
\hline Array Surface Area $-\mathrm{km}^{\wedge} 2$ & 0.1 & 1.2 & 2.4 \\
\hline Average Linear Array Density & $1.7 \%$ & $4.9 \%$ & $4.9 \%$ \\
\hline Cumulative Hydraulic Fluid Volume $\left(\mathrm{m}^{\wedge} 3\right)$ & 12.8 & 256 & 499 \\
\hline \multicolumn{4}{|l|}{ Array Performance } \\
\hline Number of devices & 1 & 20 & 39 \\
\hline Average electrical power (MW) & 0.2 & 3.1 & 6.0 \\
\hline Rated electrical power (MW) & 0.517 & 10.3 & 20.2 \\
\hline Annual Energy Delivered to Grid (MWh/year) & 1,400 & 27,200 & 53,000 \\
\hline Average \# of Households & 119 & 2,385 & 4,650 \\
\hline Displaced CO2 (tons) & 840 & 16,320 & 31,800 \\
\hline
\end{tabular}




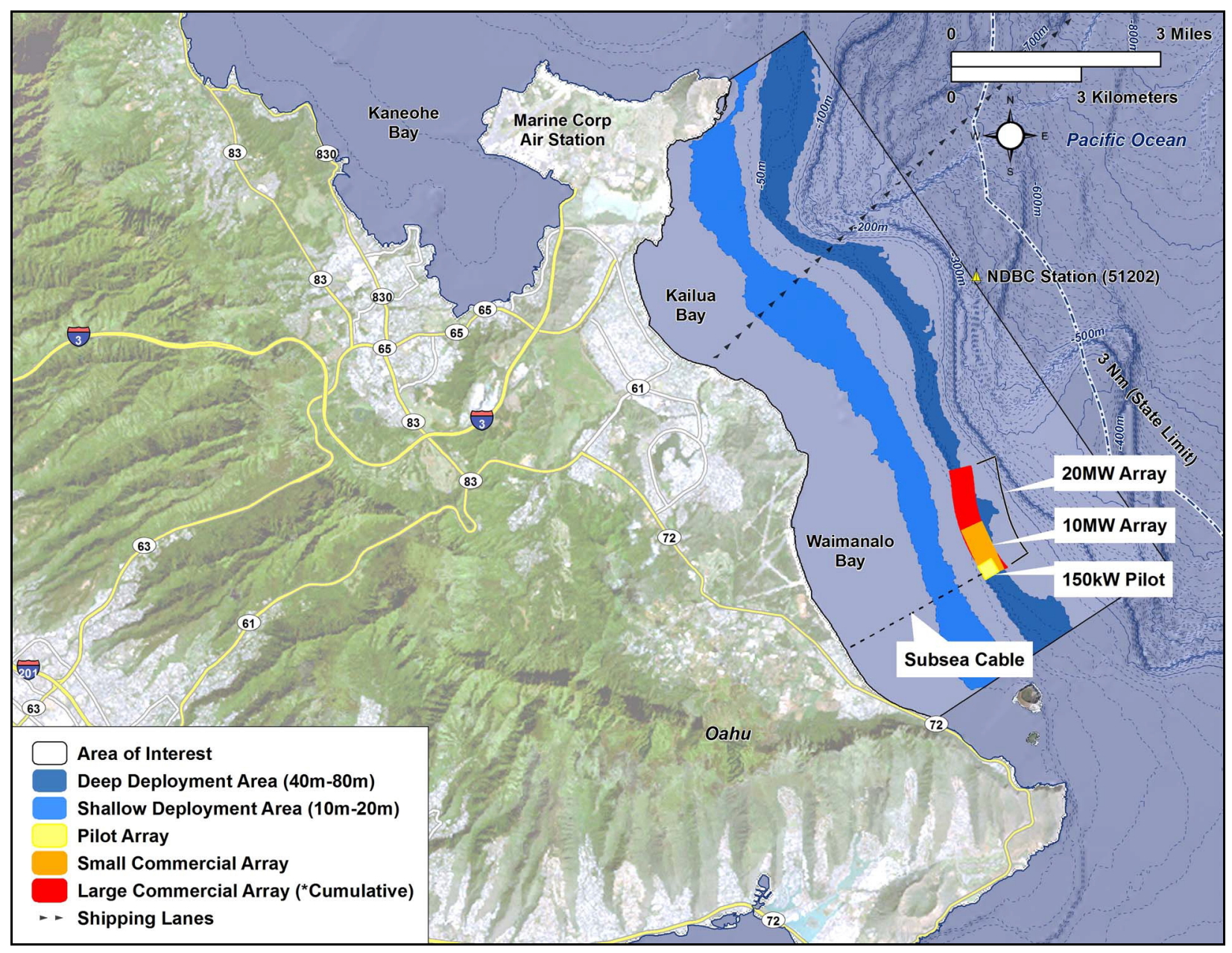

Figure 4 - Pelamis Scenario Options (Hawaii)

\subsubsection{Potential effects of project on physical site characteristics}

Effects of the project on physical attributes, including water quality, sediment transport, and wave height are anticipated to be minimal and potentially immeasurable at the small commercial project scale. Boats used for construction and operations and maintenance may release small amounts of oils and other chemicals but it is likely these will be in extremely small amounts. Seabed disturbance associated with project construction, including directional drilling for laying cable, is also likely to be temporary and spatially minimal due to the sand substrate. Structures on the bottom (anchors, moorings) and on the surface are also considered to have low impacts to sediment transport and wave height due to the small scale of the project. The potential effects of project actions on physical site characteristics are detailed in Appendix E, and all effects rated with a medium, high, or unknown risk to the indicator are detailed in Table 17. 


\subsubsection{Exposure of pinnipeds and cetaceans to project}

Cetacean and pinniped indicator species were selected for the Makapu'u wave energy project effects analysis using the same indicator selection process as was detailed for the Humboldt wave energy project (Appendix D); this approach considered the temporal distribution, habitat, and abundance for all pinnipeds and cetacean species that could occur in the project area. The following cetacean and pinniped species were selected as indicators: 1) humpback whale; 2) false killer whale; 3) spinner porpoise; 4) bottlenose dolphin; and 5) Hawaiian monk seal lion (listed as federally endangered). For each indicator, the spatial and temporal exposure of project actions to the indicator was determined, and the overlap of the project actions' potential effects with the indicator's critical life stage, behavior, or resource was evaluated ("exposure"). The exposure to cetacean and pinniped indicators as a result of project actions is detailed in Appendix E and summarized in Table 17.

Table 17 - Summary of exposure (medium, high, unknown) of cetaceans and pinnipeds to a small commercial scale Pelamis Wave Power P-2 project at Makapu'u.

\begin{tabular}{|c|c|c|}
\hline Indicator & $\begin{array}{l}\text { Degree of overlap with } \\
\text { project actions }\end{array}$ & Action and potential effect \\
\hline Spinner dolphins & High & $\begin{array}{l}\text { Noise and vibration during directional drilling resulting in } \\
\text { disruption of shallow-water nearshore resting periods }\end{array}$ \\
\hline Hawaiian monk seals & Medium-high & $\begin{array}{l}\text { Noise and vibration during construction, decommissioning, } \\
\text { and/or emitted from the wave devices resulting in avoidance } \\
\text { or masking of communication and environmental cues }\end{array}$ \\
\hline Humpback whales & Medium & $\begin{array}{l}\text { Noise and vibration from boats during maintenance and noise } \\
\text { emitted from the wave devices resulting in avoidance or } \\
\text { masking of communication and environmental cues }\end{array}$ \\
\hline Humpback whales & Medium & $\begin{array}{l}\text { Direct impact (collision injuries) with boats associated with } \\
\text { maintenance activities }\end{array}$ \\
\hline Humpback whales & Medium & $\begin{array}{l}\text { Toxicity from potential oil/chemical releases from boats during } \\
\text { maintenance or emitted from wave devices }\end{array}$ \\
\hline Humpback whales & Medium & $\begin{array}{l}\text { Entanglement with lost fishing gear caught on devices, } \\
\text { moorings, and/or loose cables }\end{array}$ \\
\hline Humpback whales & Medium & $\begin{array}{l}\text { Visual disorientation from navigation lights on wave devices, } \\
\text { which could lead to collision }\end{array}$ \\
\hline All & Unknown & Disorientation or behavioral changes from EMF \\
\hline
\end{tabular}

\subsubsection{Exposure of fish to project}

Fish indicator species were selected for the Makapu'u wave energy project effects analysis using the same indicator selection process as was detailed for the Humboldt wave energy project (Appendix D); the approach considered if fish species are known to occur in nearshore Oahu waters, if suitable habitat either 
occurs in the project area or would be created by the project, and if aspects of their behavior and/or biology would make them likely to be affected by the project. Fish species were also selected if the project area is located within designated Essential Fish Habitat (EFH), and/or if they are designated as federally threatened or endangered and occur in the project area. The following fish indicator species groups were selected: 1) bottomfishes; 2) mahimahi and scombrids (tunas, wahoo); 3) billfishes; and 4) sharks (e.g., Oceanic whitetip, Tiger, Shortfin mako, and Longfin mako). There are no federally threatened or endangered fish species in the project area, and the project is located in a bottomfish restricted fishing area (HDAR undated). For each indicator, the spatial and temporal exposure of project actions to the indicator was determined, and the overlap of the project actions' potential effects with the indicator's critical life stage, behavior, or resource was evaluated ("exposure"). The exposure to fish indicators as a result of project actions is detailed in Appendix E and summarized in Table 18.

Table 18 - Summary of exposure (medium, high, unknown) of fish indicators to a small commercial scale Pelamis Wave Power P-2 project at Makapu'u.

\begin{tabular}{|c|c|c|}
\hline Indicator & $\begin{array}{c}\text { Degree of } \\
\text { overlap with } \\
\text { project } \\
\text { actions }\end{array}$ & Action and potential effect \\
\hline $\begin{array}{l}\text { Billfishes; mahimahi and } \\
\text { scombrids; sharks }\end{array}$ & High & $\begin{array}{l}\text { Attraction to prey aggregated at structures on water's } \\
\text { surface (FAD effect) }\end{array}$ \\
\hline Mahimahi and scombrids; sharks & Medium & $\begin{array}{l}\text { Noise and vibration from boat traffic during construction, } \\
\text { maintenance, and decommissioning altering behavior or } \\
\text { affecting communication }\end{array}$ \\
\hline $\begin{array}{l}\text { Bottomfishes; mahimahi and } \\
\text { scombrids; sharks }\end{array}$ & Medium & $\begin{array}{l}\text { Noise and vibration during construction, directional drilling, } \\
\text { and/or decommissioning altering behavior or affecting } \\
\text { communication }\end{array}$ \\
\hline Bottomfishes; sharks & Medium & $\begin{array}{l}\text { Temporary habitat loss and changes in prey resources from } \\
\text { seabed disturbance during construction, directional, drilling, } \\
\text { or decommissioning activities }\end{array}$ \\
\hline Mahimahi and scombrids; sharks & Medium & $\begin{array}{l}\text { Attraction to prey aggregated around construction and } \\
\text { decommissioning lights, and/or navigation lights on wave } \\
\text { devices (beneficial effect) }\end{array}$ \\
\hline $\begin{array}{l}\text { Bottomfishes; mahimahi and } \\
\text { scombrids; sharks }\end{array}$ & Unknown & Disorientation or behavioral changes from EMF \\
\hline Bottomfishes & Medium & Aggregation of fishes around structures in the water column \\
\hline
\end{tabular}




\subsubsection{Exposure of sea turtles to project}

Sea turtle indicators were selected for the Makapu'u wave energy project effects analysis by determining which sea turtle species could occur in the project area and be affected by project activities. Of the five sea turtles known to occur in the Hawaiian Islands the green sea turtle (listed as federally threatened) and Hawksbill sea turtle (listed as federally endangered) were selected as indicators because they nest on Oahu Island and forage in nearshore waters (USN 2005). The risk to these two indicator species as a result of project actions is summarized in Table 19. For both species, the spatial and temporal exposure of project actions to the indicator was determined, and the overlap of the effects of project actions with the indicator's critical life stage, behavior, or resource was evaluated ("exposure"). The exposure to the sea turtle indicators as a result of project actions is detailed in Appendix E and summarized in Table 19.

Table 19 - Summary of exposure (medium, high, unknown) of sea turtles to a small commercial scale Pelamis Wave Power P-2 project at Makapu'u.

\begin{tabular}{|c|c|c|}
\hline Indicator & $\begin{array}{l}\text { Degree of } \\
\text { overlap with } \\
\text { project actions }\end{array}$ & Action and potential effect \\
\hline $\begin{array}{l}\text { Green sea turtle and } \\
\text { Hawksbill sea turtle }\end{array}$ & Medium-High & $\begin{array}{l}\text { Attraction to and disorientation of hatchlings around construction } \\
\text { and decommissioning lights, and/or navigation lights on devices, } \\
\text { resulting in increased vulnerability to predation }\end{array}$ \\
\hline $\begin{array}{l}\text { Green sea turtle and } \\
\text { Hawksbill sea turtle }\end{array}$ & Medium & $\begin{array}{l}\text { Direct impact (collision injuries) with boats associated with } \\
\text { construction, maintenance, and/or decommissioning }\end{array}$ \\
\hline $\begin{array}{l}\text { Green sea turtle and } \\
\text { Hawksbill sea turtle }\end{array}$ & Medium & $\begin{array}{l}\text { Noise and vibration from boat traffic during construction, } \\
\text { maintenance, and decommissioning resulting in disturbance and/or } \\
\text { avoidance of area }\end{array}$ \\
\hline $\begin{array}{l}\text { Green sea turtle and } \\
\text { Hawksbill sea turtle }\end{array}$ & Medium & $\begin{array}{l}\text { Noise and vibration during construction, directional drilling, } \\
\text { decommissioning, and noise emitted from wave devices resulting in } \\
\text { disturbance and/or avoidance of area }\end{array}$ \\
\hline $\begin{array}{l}\text { Green sea turtle and } \\
\text { Hawksbill sea turtle }\end{array}$ & Medium & $\begin{array}{l}\text { Temporary habitat loss and changes in prey resources from seabed } \\
\text { disturbance during construction, directional, drilling, or } \\
\text { decommissioning }\end{array}$ \\
\hline $\begin{array}{l}\text { Green sea turtle and } \\
\text { Hawksbill sea turtle }\end{array}$ & Medium & $\begin{array}{l}\text { Collision with devices and entanglement with lost fishing gear } \\
\text { caught on devices, moorings, and/or loose cables }\end{array}$ \\
\hline $\begin{array}{l}\text { Green sea turtle and } \\
\text { Hawksbill sea turtle }\end{array}$ & Unknown & Disorientation or behavioral changes from EMF \\
\hline
\end{tabular}




\subsubsection{Exposure of marine birds to project}

Marine bird indicators were selected for the Makapu'u wave energy project effects analysis using the same indicator selection process as was detailed for the Humboldt wave energy project (Appendix D); this approach determined the foraging mode, foraging habitat and diurnal rhythms of all marine bird species that could occur in the project area. Nearby Manana Island is a seabird sanctuary. The following species or species groups were selected as indicators: 1) albatrosses, shearwaters, and storm-petrels; 2) noddies and terns; 3) white-tailed tropicbird, brown booby, and great frigatebirds. The risk to marine bird indicators as a result of project actions is summarized in Table 20. For each indicator, the spatial and temporal exposure of project actions to the indicator was determined, and the overlap of the project actions' potential effects with the indicator's critical life stage, behavior, or resource was evaluated ("exposure"). The exposure to marine bird indicators as a result of project actions is detailed in Appendix E and summarized in Table 20.

Table 20 - Summary of exposure (medium, high, unknown) of marine bird indicators to a small commercial scale Pelamis Wave Power P-2 project at Makapu'u.

\begin{tabular}{|c|c|c|}
\hline Indicator & $\begin{array}{l}\text { Degree of } \\
\text { overlap with } \\
\text { project actions }\end{array}$ & Action and potential effect \\
\hline $\begin{array}{l}\text { Albatrosses, shearwaters, and } \\
\text { storm-petrels }\end{array}$ & Medium & $\begin{array}{l}\text { Attraction to and/or disorientation by construction/ } \\
\text { deconstuction lights or lights on the wave devices while } \\
\text { staging in nearshore waters }\end{array}$ \\
\hline $\begin{array}{l}\text { Noddies and terns; white-tailed } \\
\text { tropicbird, brown booby, and great } \\
\text { frigatebirds }\end{array}$ & Medium-High & $\begin{array}{l}\text { Noise and vibration from boat traffic during construction, } \\
\text { maintenance, and decommissioning resulting in disruption of } \\
\text { foraging and/or avoidance of area }\end{array}$ \\
\hline $\begin{array}{l}\text { Noddies and terns; white-tailed } \\
\text { tropicbird, brown booby, and great } \\
\text { frigatebirds }\end{array}$ & Medium-High & $\begin{array}{l}\text { Noise and vibration during construction, directional drilling, } \\
\text { decommissioning, and noise emitted from devices resulting in } \\
\text { disruption of foraging and/or avoidance of area }\end{array}$ \\
\hline $\begin{array}{l}\text { Noddies and terns; white-tailed } \\
\text { tropicbird, brown booby, and great } \\
\text { frigatebirds }\end{array}$ & Medium-High & $\begin{array}{l}\text { Toxicity from oil/chemical releases from boats, construction } \\
\text { activities, or emitted from devices }\end{array}$ \\
\hline $\begin{array}{l}\text { Albatrosses, shearwaters, and } \\
\text { storm-petrels; noddies and terns; } \\
\text { white-tailed tropicbird, brown } \\
\text { booby, and great frigatebirds }\end{array}$ & Medium-High & $\begin{array}{l}\text { Collision with devices while flying, attraction to aggregated } \\
\text { prey at structures on the water's surface (FAD effect) }\end{array}$ \\
\hline
\end{tabular}




\subsubsection{Exposure of coral reefs to project}

Coral was selected for the Makapu'u wave energy project effects because of its importance as habitat to tropical fish species, and coral reefs are designated as Essential Fish Habitat. Coral reefs can be found up to $80-100 \mathrm{~m}$ in depth; however, coral reef accretion appears to be limited to depths of about $50 \mathrm{~m}$ due to light limitation and bio-erosion (Grigg 2006). The vast majority of corals along the coast of Hawaiian Islands are found near the shoreline at depths of less than $40 \mathrm{~m}$ (AECOS Inc. 2002). Therefore, effects on coral by most activities associated with the Makapu'u wave energy project are unlikely because the project area is outside the optimal zone for coral. However, directional drilling within the nearshore environment during construction could affect coral reefs because it would overlap with coral distribution (Table 21). Potential effects from directional drilling include direct impacts to coral and sedimentation associated with seabed disturbance. Excessive sedimentation associated with run-off and dredging is known to cause severe degradation of coral reefs; however, short-term sedimentation events, such as what would occur as a result of seabed disturbance during directional drilling, would likely only have localized or negligible effects on corals (Rogers 1990). Direct impacts to coral are possible during directional drilling, but could be avoided or minimized through pre-construction surveys and mapping.

Table 21 - Summary of exposure (medium, high, unknown) of coral reefs to a small commercial scale Pelamis Wave Power P-2 project at Makapu'u.

\begin{tabular}{|l|l|l|}
\hline \multicolumn{1}{|c|}{ Indicator } & $\begin{array}{c}\text { Degree of overlap with } \\
\text { project actions }\end{array}$ & \multicolumn{1}{c|}{ Action and potential effect } \\
\hline Coral reefs & Medium & $\begin{array}{l}\text { Directional drilling during construction resulting in seabed } \\
\text { disturbance and sedimentation }\end{array}$ \\
\hline Coral reefs & Medium & $\begin{array}{l}\text { Directional drilling during construction resulting in direct impacts } \\
\text { to coral }\end{array}$ \\
\hline
\end{tabular}

\subsubsection{Overall risk to indicators for a small commercial scale Pelamis P-2 project at Makapu'u}

Once the exposure of indicators to project actions was determined based on the overlap with spatial, temporal, and critical life stages (see previous sections and Appendix E), we assessed the overall risk of project actions to the indicators based on the potential for effects to occur. We summarized all indicators/effects that had a medium, high, or unknown risk (Table 21 and Table 22).

No project activities pose high risks to site physical characteristics (Table 22). Low risks are determined for all project activities to wave energy, sediment transport and water chemistry. Project activities that may pose medium risks to site physical characteristics include: 
- Boat traffic during project construction and decommissioning, which could cause temporary noise and vibration in the acoustic environment

- Construction and decommissioning lights, which would cause temporary effects in the visual environment

- Presence of device structures above the water surface that are visible from shore

Project activities that pose unknown risks to site physical characteristics include:

- Noise emitted from the wave energy conversion devices

Project activities that may pose medium or high risks to biological indicators are (Table 22):

- Boat traffic during all project phases, resulting in collision and noise effects on sea turtles and some pinnipeds and cetaceans

- Boat traffic during all project phases, resulting in noise effects on noddies and terns

- Construction and decommissioning of wave energy devices, resulting in temporary noise effects on some pinnipeds and cetaceans; noddi es and terns; and sea turtles

- Seabed disturbance from construction, directional drilling, and decommissioning activities, resulting in temporary loss of foraging habitat for sea turtles

- Directional drilling during the construction phase of the project, resulting in temporary noise disturbance effects on spinner dolphins resting in nearshore areas

- Construction and deck lights used in construction and decommissioning, and navigation lights on devices, causing disorientation and/or collision with lights or structures, aggregation, and/or increased vulnerability to predation for Hawaiian monk seals; sea turtle hatchlings; albatrosses, shearwaters, and storm-petrels; mahimahi and scombrids; and sharks

- Movement of devices and mooring lines attached to wave energy devices causing injury to young of the year humpback whales

- Surface structures resulting in FAD effects, attracting billfishes; mahimahi and scombrids; and sharks

- Underwater structures becoming entangled with lost fishing gear, resulting in injury or entrapment for humpback whales; Hawaiian monk seals; and sea turtles; these species could also collide with underwater structures

- Directional drilling during construction resulting in direct impacts to coral 
Project activities that pose unknown risks to biological indicators are (Table 22):

- Construction and deck lights used in construction and decommissioning, and navigation lights on structures could cause disorientation, collision with lights or structures, and/or enhanced foraging for Hawaiian monk seals

- Generation of EMF could cause changes in orientation and behavior in bottomfishes; mahimahi and scombrids; sharks; sea turtles; and all marine mammal indicators

- Noise emitted from the wave energy devices, resulting in altered behavior, avoidance, and masked environmental cues and communication signals for Hawaiian monk seals; humpback whales; noddies and terns; and sea turtles

- Underwater structures could attract bottomfishes; mahimahi and scombrids; billfishes; and sharks due to reef effects and result in changes to predator/prey relationships, and/or species composition

- Surface structures could attract species due to prey aggregations (FAD effects), and/or increase collision risks for all marine bird indicators

We note that mitigation measures are known for most of these high and unknown effects. This study did not extend to evaluating the effectiveness of mitigation measures, and whether mitigation could reduce risk to less than significant levels was not evaluated. 
Table 22 - Overall risk (medium, high, unknown) to site physical characteristics for a small commercial scale Pelamis Wave Power P-2 project at the Makapu'u site.

\begin{tabular}{|c|c|c|c|c|c|c|c|}
\hline Indicator & Project activity & Project action & $\begin{array}{l}\text { Description of action's } \\
\text { effect on indicator species }\end{array}$ & $\begin{array}{l}\text { Overall risk to indicator } \\
\text { (med, high, unknown) }\end{array}$ & $\begin{array}{c}\text { Effect type } \\
\text { (in/direct, } \\
\text { beneficial, } \\
\text { neutral, } \\
\text { adverse) } \\
\end{array}$ & $\begin{array}{c}\text { Uncertainty } \\
\text { warrants } \\
\text { further study? }\end{array}$ & $\begin{array}{l}\text { Potential } \\
\text { mitigation }\end{array}$ \\
\hline \multicolumn{8}{|c|}{ Construction } \\
\hline $\begin{array}{l}\text { Acoustic } \\
\text { environment }\end{array}$ & Boat traffic & $\begin{array}{l}\text { Noise and } \\
\text { vibration }\end{array}$ & $\begin{array}{l}\text { Propellers cavitate, causing } \\
\text { pressure differences }\end{array}$ & $\begin{array}{l}\text { Med, noise could be } \\
\text { elevated but short-term } \\
\text { and attenuated by sea } \\
\text { conditions, ambient noise }\end{array}$ & $\begin{array}{l}\text { Direct, } \\
\text { adverse }\end{array}$ & $\begin{array}{l}\text { No, effects } \\
\text { reasonably } \\
\text { described }\end{array}$ & $\begin{array}{l}\text { Need for } \\
\text { mitigation not } \\
\text { established }\end{array}$ \\
\hline $\begin{array}{l}\text { Acoustic } \\
\text { environment }\end{array}$ & $\begin{array}{l}\text { Construction of electrical } \\
\text { collector system, moorings } \\
\text { and foundations, device } \\
\text { installation }\end{array}$ & $\begin{array}{l}\text { Noise and } \\
\text { vibration }\end{array}$ & $\begin{array}{l}\text { Adds to existing natural and } \\
\text { man-made noise in project } \\
\text { area }\end{array}$ & $\begin{array}{l}\text { Med, noise could be } \\
\text { elevated but short-term } \\
\text { and attenuated by sea } \\
\text { conditions, ambient noise }\end{array}$ & $\begin{array}{l}\text { Direct, } \\
\text { adverse }\end{array}$ & $\begin{array}{l}\text { No, effects } \\
\text { reasonably } \\
\text { described }\end{array}$ & $\begin{array}{l}\text { Minimize and } \\
\text { concentrate } \\
\text { noise }\end{array}$ \\
\hline $\begin{array}{l}\text { Visual } \\
\text { environment }\end{array}$ & $\begin{array}{l}\text { Construction of electrical } \\
\text { collector system, moorings } \\
\text { and foundations, device } \\
\text { installation }\end{array}$ & $\begin{array}{l}\text { Construction } \\
\text { and deck lights }\end{array}$ & $\begin{array}{l}\text { Construction lights much } \\
\text { brighter than vessel lights }\end{array}$ & $\begin{array}{l}\text { Med, lights may be visible } \\
\text { from shore depending on } \\
\text { sea and weather } \\
\text { conditions }\end{array}$ & $\begin{array}{l}\text { Direct, } \\
\text { adverse }\end{array}$ & $\begin{array}{l}\text { No, effects } \\
\text { reasonably } \\
\text { described }\end{array}$ & $\begin{array}{l}\text { Limit construction } \\
\text { to daylight hours }\end{array}$ \\
\hline \multicolumn{8}{|c|}{ Operation and Maintenance } \\
\hline $\begin{array}{l}\text { Visual } \\
\text { environment }\end{array}$ & $\begin{array}{l}\text { Structures on water's } \\
\text { surface }\end{array}$ & $\begin{array}{l}\text { Navigation } \\
\text { lights }\end{array}$ & $\begin{array}{l}\text { Devices will have lights for } \\
\text { navigational safety visible } \\
\text { from } 2 \text { to } 5 \mathrm{~nm} \text {. }\end{array}$ & $\begin{array}{l}\text { Med, device lights have } \\
\text { low profile and visible } 1 \text { to } \\
2 \text { mi from shore }\end{array}$ & $\begin{array}{l}\text { Direct, } \\
\text { adverse }\end{array}$ & $\begin{array}{l}\text { Yes, evaluate } \\
\text { visibility from } \\
\text { shore }\end{array}$ & $\begin{array}{l}\text { Need for } \\
\text { mitigation not } \\
\text { established }\end{array}$ \\
\hline $\begin{array}{l}\text { Acoustic } \\
\text { environment }\end{array}$ & $\begin{array}{l}\text { Operation of turbines or } \\
\text { other moving parts of } \\
\text { devices }\end{array}$ & $\begin{array}{l}\text { Noise and } \\
\text { vibration }\end{array}$ & $\begin{array}{l}\text { Adds to existing natural and } \\
\text { man-made noise in project } \\
\text { area }\end{array}$ & Unknown & Unknown & $\begin{array}{l}\text { Yes, sound } \\
\text { levels should } \\
\text { be determined }\end{array}$ & $\begin{array}{l}\text { Need for } \\
\text { mitigation not } \\
\text { established }\end{array}$ \\
\hline \multicolumn{8}{|c|}{ Decommissioning } \\
\hline $\begin{array}{l}\text { Acoustic } \\
\text { environment }\end{array}$ & Boat traffic & $\begin{array}{l}\text { Noise and } \\
\text { vibration }\end{array}$ & $\begin{array}{l}\text { Propellers cavitate, causing } \\
\text { pressure differences }\end{array}$ & $\begin{array}{l}\text { Med, noise could be } \\
\text { elevated but short-term }\end{array}$ & $\begin{array}{l}\text { Direct, } \\
\text { adverse }\end{array}$ & $\begin{array}{l}\text { No, effects } \\
\text { reasonably } \\
\text { described }\end{array}$ & $\begin{array}{l}\text { Need for } \\
\text { mitigation not } \\
\text { established }\end{array}$ \\
\hline $\begin{array}{l}\text { Acoustic } \\
\text { environment }\end{array}$ & $\begin{array}{l}\text { Decommissioning of } \\
\text { structures on water's } \\
\text { surface or seabed }\end{array}$ & $\begin{array}{l}\text { Noise and } \\
\text { vibration }\end{array}$ & $\begin{array}{l}\text { Adds to existing natural and } \\
\text { man-made noise in project } \\
\text { area }\end{array}$ & $\begin{array}{l}\text { Med, noise could be } \\
\text { elevated but short-term }\end{array}$ & $\begin{array}{l}\text { Direct, } \\
\text { adverse }\end{array}$ & $\begin{array}{l}\text { No, effects } \\
\text { reasonably } \\
\text { described }\end{array}$ & $\begin{array}{l}\text { Need for } \\
\text { mitigation not } \\
\text { established }\end{array}$ \\
\hline $\begin{array}{l}\text { Visual } \\
\text { environment }\end{array}$ & $\begin{array}{l}\text { Decommissioning of } \\
\text { structures on water's } \\
\text { surface or seabed }\end{array}$ & $\begin{array}{l}\text { Deconstruction } \\
\text { lights }\end{array}$ & $\begin{array}{l}\text { Deconstruction lights much } \\
\text { brighter than vessel lights }\end{array}$ & $\begin{array}{l}\text { Med, lights may be visible } \\
\text { from shore depending on } \\
\text { sea and weather } \\
\text { conditions }\end{array}$ & $\begin{array}{l}\text { Direct, } \\
\text { adverse }\end{array}$ & $\begin{array}{l}\text { No, effects } \\
\text { reasonably } \\
\text { described }\end{array}$ & $\begin{array}{l}\text { Limit } \\
\text { deconstruction to } \\
\text { daylight hours }\end{array}$ \\
\hline
\end{tabular}


Table 23 - Overall risk (medium, high, unknown) to indicator species or species groups for a small commercial Pelamis P-2 project at the Makapu'u site.

\begin{tabular}{|c|c|c|c|c|c|c|c|}
\hline Indicator & Project activity & Project action & $\begin{array}{l}\text { Description of } \\
\text { action's effect on } \\
\text { indicator species }\end{array}$ & $\begin{array}{c}\text { Overall risk to } \\
\text { indicator (med, } \\
\text { high, } \\
\text { unknown) }\end{array}$ & $\begin{array}{l}\text { Effect type } \\
\text { (in/direct, } \\
\text { beneficial, } \\
\text { neutral, } \\
\text { adverse) } \\
\end{array}$ & $\begin{array}{l}\text { Uncertainty } \\
\text { warrants further } \\
\text { study? }\end{array}$ & Potential mitigation \\
\hline \multicolumn{8}{|c|}{ Construction } \\
\hline $\begin{array}{l}\text { Green sea turtles, } \\
\text { hawksbill sea turtles; } \\
\text { bottlenose dolphin; } \\
\text { humpback whale; } \\
\text { Hawaiian monk seal }\end{array}$ & Boat traffic & Direct impact & $\begin{array}{l}\text { Collision and injury or } \\
\text { mortality }\end{array}$ & Med-high & Direct, adverse & $\begin{array}{l}\text { No, effects } \\
\text { reasonably } \\
\text { described }\end{array}$ & $\begin{array}{l}\text { Reduce vessel } \\
\text { speed, minimize } \\
\text { vessel path overlap } \\
\text { with coastal areas } \\
\text { frequented by } \\
\text { bottlenose dolphin }\end{array}$ \\
\hline $\begin{array}{l}\text { Noddies and terns; } \\
\text { green sea turtles, } \\
\text { hawksbill sea turtles } \\
\end{array}$ & Boat traffic & $\begin{array}{l}\text { Noise and } \\
\text { vibration }\end{array}$ & $\begin{array}{l}\text { Possible movement } \\
\text { away from area and } \\
\text { disruption of foraging }\end{array}$ & Med & Indirect, adverse & $\begin{array}{l}\text { No, effects } \\
\text { reasonably } \\
\text { described }\end{array}$ & 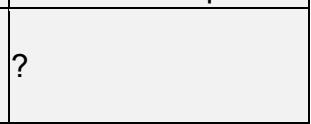 \\
\hline $\begin{array}{l}\text { Noddies and terns; } \\
\text { green sea turtles, } \\
\text { hawksbill sea turtles; } \\
\text { Hawaiian monk seal }\end{array}$ & $\begin{array}{l}\text { Construction of } \\
\text { electrical collector } \\
\text { system, moorings/ } \\
\text { foundation; device } \\
\text { installation }\end{array}$ & $\begin{array}{l}\text { Noise and } \\
\text { vibration }\end{array}$ & $\begin{array}{l}\text { Movement from area } \\
\text { and disruption of } \\
\text { foraging; Reduced } \\
\text { hearing sensitivity } \\
\text { could mask } \\
\text { environmental cues }\end{array}$ & Med-high & Indirect, adverse & $\begin{array}{l}\text { No, effects } \\
\text { reasonably } \\
\text { described }\end{array}$ & $?$ \\
\hline $\begin{array}{l}\text { Albatrosses, } \\
\text { shearwaters, and } \\
\text { storm-petrels; green } \\
\text { sea turtles, hawksbill } \\
\text { sea turtles }\end{array}$ & $\begin{array}{l}\text { Construction of } \\
\text { electrical collector } \\
\text { system, moorings/ } \\
\text { foundation; device } \\
\text { installation }\end{array}$ & $\begin{array}{l}\text { Construction and } \\
\text { deck lights }\end{array}$ & $\begin{array}{l}\text { Attraction/ } \\
\text { disorientation of birds } \\
\text { in nearshore waters } \\
\text { before flying to nests, } \\
\text { disorientation of chicks } \\
\text { or sea turtle } \\
\text { hatchlings, more } \\
\text { vulnerable to predation }\end{array}$ & Med & Direct, adverse & $\begin{array}{l}\text { No, effects } \\
\text { reasonably } \\
\text { described }\end{array}$ & $\begin{array}{l}\text { Limit construction to } \\
\text { daylight hours }\end{array}$ \\
\hline Hawaiian monk seal & $\begin{array}{l}\text { Construction of } \\
\text { electrical collector } \\
\text { system, moorings/ } \\
\text { foundation; device } \\
\text { installation } \\
\end{array}$ & $\begin{array}{l}\text { Construction and } \\
\text { deck lights }\end{array}$ & $\begin{array}{l}\text { Visual disorientation } \\
\text { could lead to collision, } \\
\text { but could also enhance } \\
\text { foraging on species } \\
\text { attracted to light }\end{array}$ & Unknown & $\begin{array}{l}\text { Direct and } \\
\text { indirect, adverse } \\
\text { and beneficial }\end{array}$ & $\begin{array}{l}\text { Yes, use of } \\
\text { structures at night } \\
\text { could be measured }\end{array}$ & $\begin{array}{l}\text { Limit construction to } \\
\text { daylight hours }\end{array}$ \\
\hline $\begin{array}{l}\text { Green sea turtles, } \\
\text { hawksbill sea turtles }\end{array}$ & $\begin{array}{l}\text { Construction of } \\
\text { electrical collector } \\
\text { system, moorings/ } \\
\text { foundation; device } \\
\text { installation }\end{array}$ & $\begin{array}{l}\text { Seabed } \\
\text { disturbance }\end{array}$ & $\begin{array}{l}\text { Temporary loss of } \\
\text { foraging habitat }\end{array}$ & Med & Indirect, adverse & $\begin{array}{l}\text { No, effects } \\
\text { reasonably } \\
\text { described }\end{array}$ & $?$ \\
\hline
\end{tabular}




\begin{tabular}{|c|c|c|c|c|c|c|c|}
\hline Spinner dolphins & $\begin{array}{l}\text { Directional drilling, } \\
\text { and laying cable } \\
\text { under/on seabed }\end{array}$ & $\begin{array}{l}\text { Noise and } \\
\text { vibration }\end{array}$ & $\begin{array}{l}\text { Avoidance of } \\
\text { nearshore area, } \\
\text { disruption of resting if } \\
\text { drilling in area used by } \\
\text { resting dolphins }\end{array}$ & High & Direct, adverse & $\begin{array}{l}\text { No, effects } \\
\text { reasonably } \\
\text { described }\end{array}$ & $\begin{array}{l}\text { Avoid construction in } \\
\text { areas where spinner } \\
\text { dolphins rest }\end{array}$ \\
\hline $\begin{array}{l}\text { Green sea turtles, } \\
\text { hawksbill sea turtles }\end{array}$ & $\begin{array}{l}\text { Directional drilling, } \\
\text { and laying cable } \\
\text { under/on seabed }\end{array}$ & $\begin{array}{l}\text { Seabed } \\
\text { disturbance }\end{array}$ & $\begin{array}{l}\text { Temporary loss of } \\
\text { foraging habitat }\end{array}$ & Med & Indirect, adverse & $\begin{array}{l}\text { No, effects } \\
\text { reasonably } \\
\text { described }\end{array}$ & $?$ \\
\hline Coral reefs & $\begin{array}{l}\text { Directional drilling, } \\
\text { and laying cable } \\
\text { under/on seabed }\end{array}$ & Direct impact & Loss of coral & Med & Direct, adverse & $\begin{array}{l}\text { No, effects } \\
\text { reasonably } \\
\text { described }\end{array}$ & $\begin{array}{l}\text { Pre-construction } \\
\text { surveys and } \\
\text { avoidance }\end{array}$ \\
\hline \multicolumn{8}{|c|}{ Operation and Maintenance } \\
\hline $\begin{array}{l}\text { Humpback whale, } \\
\text { green sea turtles, } \\
\text { hawksbill sea turtles, } \\
\text { Hawaiian monk seal }\end{array}$ & Boat traffic & Direct impact & Collision injuries & Med-high & Direct, adverse & $\begin{array}{l}\text { No, effects } \\
\text { reasonably } \\
\text { described }\end{array}$ & $\begin{array}{l}\text { Reduce vessel } \\
\text { speed }\end{array}$ \\
\hline $\begin{array}{l}\text { Humpback whale, } \\
\text { green sea turtles, } \\
\text { hawksbill sea turtles }\end{array}$ & Boat traffic & $\begin{array}{l}\text { Noise and } \\
\text { vibration }\end{array}$ & $\begin{array}{l}\text { Possible movement } \\
\text { from area and } \\
\text { disruption of foraging; } \\
\text { masks environmental } \\
\text { cues, communication }\end{array}$ & Med-high & Indirect, adverse & $\begin{array}{l}\text { No, effects } \\
\text { reasonably } \\
\text { described }\end{array}$ & $?$ \\
\hline $\begin{array}{l}\text { Hawaiian monk seal; } \\
\text { humpback whales; } \\
\text { noddies and terns; } \\
\text { green sea turtles, } \\
\text { hawksbill sea turtles }\end{array}$ & $\begin{array}{l}\text { Operation of turbines } \\
\text { or other moving } \\
\text { parts of devices }\end{array}$ & $\begin{array}{l}\text { Noise and } \\
\text { vibration }\end{array}$ & $\begin{array}{l}\text { Possible movement } \\
\text { from area, disruption of } \\
\text { foraging, masks } \\
\text { environmental cues, } \\
\text { communication }\end{array}$ & Med-high & Unknown & $\begin{array}{l}\text { Yes, noise from } \\
\text { devices and } \\
\text { ambient site } \\
\text { condtions affecting } \\
\text { noise are unknown }\end{array}$ & $?$ \\
\hline Humpback whale & $\begin{array}{l}\text { Operation of turbines } \\
\text { or other moving } \\
\text { parts of devices }\end{array}$ & $\begin{array}{l}\text { Moving device } \\
\text { parts }\end{array}$ & $\begin{array}{l}\text { Movement of devices } \\
\text { and mooring lines } \\
\text { could injure animals }\end{array}$ & $\begin{array}{l}\text { High for young } \\
\text { of the year }\end{array}$ & Direct, adverse & $\begin{array}{l}\text { No, effects } \\
\text { reasonably } \\
\text { described }\end{array}$ & $\begin{array}{l}\text { Need for mitigation } \\
\text { not yet established }\end{array}$ \\
\hline $\begin{array}{l}\text { All marine mammal } \\
\text { indicators; } \\
\text { bottomfishes; } \\
\text { mahimahi and } \\
\text { scombrids; sharks; } \\
\text { green sea turtles, } \\
\text { hawksbill sea turtles } \\
\end{array}$ & $\begin{array}{l}\text { Electricity } \\
\text { conduction through } \\
\text { cable }\end{array}$ & EMF & $\begin{array}{l}\text { Effects on species } \\
\text { unknown, could } \\
\text { include behavior, } \\
\text { orientation changes }\end{array}$ & Unknown & Unknown & $\begin{array}{l}\text { Yes, literature has } \\
\text { not reached } \\
\text { consensus }\end{array}$ & $\begin{array}{l}\text { Shielding, "Faraday } \\
\text { cages", bury high- } \\
\text { voltage DC to reduce } \\
\text { EMF (EAO British } \\
\text { Columbia 2009) }\end{array}$ \\
\hline $\begin{array}{l}\text { Bottomfishes; } \\
\text { mahimahi and } \\
\text { scombrids; billfish; } \\
\text { sharks }\end{array}$ & $\begin{array}{l}\text { Structures in water } \\
\text { column and on } \\
\text { seabed, such as } \\
\text { devices, moorings } \\
\text { and footings }\end{array}$ & Structure & $\begin{array}{l}\text { Structure in water } \\
\text { column acts similarly } \\
\text { to FAD, no effect of } \\
\text { seafloor structure }\end{array}$ & Unknown & $\begin{array}{l}\text { Direct and } \\
\text { indirect, adverse } \\
\text { and beneficial }\end{array}$ & $\begin{array}{l}\text { Yes, use of } \\
\text { structures could be } \\
\text { measured }\end{array}$ & $\begin{array}{l}\text { Need for mitigation } \\
\text { not yet established }\end{array}$ \\
\hline
\end{tabular}




\begin{tabular}{|c|c|c|c|c|c|c|c|}
\hline $\begin{array}{l}\text { Humpback whales; } \\
\text { Hawaiian monk } \\
\text { seals; green sea } \\
\text { turtles, hawksbill sea } \\
\text { turtles }\end{array}$ & $\begin{array}{l}\text { Structures in water } \\
\text { column and on } \\
\text { seabed, such as } \\
\text { devices, moorings } \\
\text { and footings }\end{array}$ & Structure & $\begin{array}{l}\text { Entanglement with } \\
\text { devices or lost fishing } \\
\text { gear, collision with } \\
\text { structures }\end{array}$ & High & Direct, adverse & $\begin{array}{l}\text { Yes, uncertain if } \\
\text { entanglement will } \\
\text { occur }\end{array}$ & $\begin{array}{l}\text { Monitoring and } \\
\text { removal of lost } \\
\text { fishing gear will } \\
\text { reduce entanglement }\end{array}$ \\
\hline $\begin{array}{l}\text { Albatrosses, } \\
\text { shearwaters, and } \\
\text { storm-petrels; green } \\
\text { sea turtles and } \\
\text { hawksbill sea turtles }\end{array}$ & $\begin{array}{l}\text { Structures on } \\
\text { water's surface }\end{array}$ & Navigation lights & $\begin{array}{l}\text { Attraction/ } \\
\text { disorientation of birds } \\
\text { in nearshore waters } \\
\text { before flying to nests, } \\
\text { disorientation of chicks } \\
\text { or sea turtle } \\
\text { hatchlings, more } \\
\text { vulnerable to predation }\end{array}$ & High & Direct, adverse & $\begin{array}{l}\text { No, effects } \\
\text { reasonably } \\
\text { described }\end{array}$ & $\begin{array}{l}\text { Minimize lighting, } \\
\text { design lights so not } \\
\text { visible from shore }\end{array}$ \\
\hline $\begin{array}{l}\text { Mahimahi and } \\
\text { scombrids; sharks }\end{array}$ & $\begin{array}{l}\text { Structures on } \\
\text { water's surface }\end{array}$ & Navigation lights & $\begin{array}{l}\text { Attraction to prey } \\
\text { aggregation }\end{array}$ & Med & $\begin{array}{l}\text { Indirect and } \\
\text { beneficial }\end{array}$ & $\begin{array}{l}\text { Yes, use of } \\
\text { structures could be } \\
\text { measured }\end{array}$ & $\begin{array}{l}\text { Need for mitigation } \\
\text { not yet established }\end{array}$ \\
\hline $\begin{array}{l}\text { Bottomfishes; } \\
\text { mahimahi, } \\
\text { scombrids }\end{array}$ & $\begin{array}{l}\text { Structures on } \\
\text { water's surface }\end{array}$ & Structure & $\begin{array}{l}\text { FAD, changes in } \\
\text { predator/prey } \\
\text { abundance, } \\
\text { interactions }\end{array}$ & Unknown & $\begin{array}{l}\text { Direct and } \\
\text { indirect, adverse } \\
\text { and beneficial }\end{array}$ & $\begin{array}{l}\text { Yes, use of } \\
\text { structures could be } \\
\text { measured }\end{array}$ & $\begin{array}{l}\text { Need for mitigation } \\
\text { not yet established }\end{array}$ \\
\hline Billfish; sharks & $\begin{array}{l}\text { Structures on } \\
\text { water's surface }\end{array}$ & Structure & FAD & Med & $\begin{array}{l}\text { Direct and } \\
\text { indirect, adverse } \\
\text { and beneficial }\end{array}$ & $\begin{array}{l}\text { Yes, use of } \\
\text { structures could be } \\
\text { measured }\end{array}$ & $\begin{array}{l}\text { Need for mitigation } \\
\text { not yet established }\end{array}$ \\
\hline $\begin{array}{l}\text { Albatrosses, } \\
\text { shearwaters, and } \\
\text { storm-petrels } \\
\end{array}$ & $\begin{array}{l}\text { Structures on } \\
\text { water's surface }\end{array}$ & Structure & $\begin{array}{l}\text { Possible collision with } \\
\text { structures while flying }\end{array}$ & Unknown & Direct, adverse & $\begin{array}{l}\text { Yes, uncertain if } \\
\text { collision will occur }\end{array}$ & $\begin{array}{l}\text { Minimize height of } \\
\text { structure above } \\
\text { water's surface } \\
\end{array}$ \\
\hline $\begin{array}{l}\text { Noddies and terns; } \\
\text { great frigatebirds, } \\
\text { white-tailed } \\
\text { tropicbird, brown } \\
\text { booby }\end{array}$ & $\begin{array}{l}\text { Structures on } \\
\text { water's surface }\end{array}$ & Structure & $\begin{array}{l}\text { Possible attractant to } \\
\text { birds due to } \\
\text { aggregated prey (FAD } \\
\text { effect), collision while } \\
\text { flying }\end{array}$ & Unknown & $\begin{array}{l}\text { Direct and } \\
\text { indirect, } \\
\text { beneficial and } \\
\text { adverse }\end{array}$ & $\begin{array}{l}\text { Yes, uncertain if } \\
\text { collision will occur } \\
\text { or if predation on } \\
\text { other species will } \\
\text { increase }\end{array}$ & $\begin{array}{l}\text { Minimize height of } \\
\text { structure above } \\
\text { water's surface }\end{array}$ \\
\hline \multicolumn{8}{|c|}{ Decommissioning } \\
\hline $\begin{array}{l}\text { Bottlenose dolphin; } \\
\text { humpback whale; } \\
\text { Hawaiian monk seal; } \\
\text { green sea turtles, } \\
\text { hawksbill sea turtles }\end{array}$ & Boat traffic & Direct impact & $\begin{array}{l}\text { Collision and injury or } \\
\text { mortality }\end{array}$ & Med-high & Direct, adverse & $\begin{array}{l}\text { No, effects } \\
\text { reasonably well } \\
\text { understood }\end{array}$ & $\begin{array}{l}\text { Reduce vessel } \\
\text { speed, minimize } \\
\text { vessel path overlap } \\
\text { with coastal areas } \\
\text { frequented by } \\
\text { bottlenose dolphin }\end{array}$ \\
\hline
\end{tabular}


revision

\begin{tabular}{|c|c|c|c|c|c|c|c|}
\hline $\begin{array}{l}\text { Noddies and terns; } \\
\text { green sea turtles, } \\
\text { hawksbill sea turtles }\end{array}$ & Boat traffic & $\begin{array}{l}\text { Noise and } \\
\text { vibration }\end{array}$ & $\begin{array}{l}\text { Possible movement } \\
\text { away from area and } \\
\text { disruption of foraging } \\
\text { or nesting }\end{array}$ & Med & Indirect, adverse & $\begin{array}{l}\text { No, effects } \\
\text { reasonably } \\
\text { described }\end{array}$ & $?$ \\
\hline $\begin{array}{l}\text { Noddies and terns; } \\
\text { green sea turtles, } \\
\text { hawksbill sea turtles }\end{array}$ & $\begin{array}{l}\text { Decommissioning of } \\
\text { structures on water's } \\
\text { surface or seabed }\end{array}$ & $\begin{array}{l}\text { Noise and } \\
\text { vibration }\end{array}$ & $\begin{array}{l}\text { Possible movement } \\
\text { away from area and } \\
\text { disruption of foraging } \\
\text { or nesting }\end{array}$ & Med & Indirect, adverse & $\begin{array}{l}\text { No, effects } \\
\text { reasonably } \\
\text { described }\end{array}$ & $?$ \\
\hline Hawaiian monk seal & $\begin{array}{l}\text { Decommissioning of } \\
\text { structures on water's } \\
\text { surface or seabed }\end{array}$ & $\begin{array}{l}\text { Deconstruction } \\
\text { and deck lights }\end{array}$ & $\begin{array}{l}\text { Visual disorientation } \\
\text { could lead to collision, } \\
\text { but could also enhance } \\
\text { foraging on species } \\
\text { attracted to light }\end{array}$ & Unknown & $\begin{array}{l}\text { Direct and } \\
\text { indirect, } \\
\text { beneficial and } \\
\text { adverse }\end{array}$ & $\begin{array}{l}\text { No, effects } \\
\text { reasonably } \\
\text { described }\end{array}$ & $\begin{array}{l}\text { Limit } \\
\text { decommissioning to } \\
\text { daylight }\end{array}$ \\
\hline $\begin{array}{l}\text { Albatrosses, } \\
\text { shearwaters, and } \\
\text { storm-petrels; green } \\
\text { sea turtles and } \\
\text { hawksbill sea turtles }\end{array}$ & $\begin{array}{l}\text { Decommissioning of } \\
\text { structures on water's } \\
\text { surface or seabed }\end{array}$ & $\begin{array}{l}\text { Deconstruction } \\
\text { and deck lights }\end{array}$ & $\begin{array}{l}\text { Attraction/ } \\
\text { disorientation of birds } \\
\text { in nearshore waters } \\
\text { before flying to nests, } \\
\text { disorientation of chicks } \\
\text { or sea turtle } \\
\text { hatchlings, more } \\
\text { vulnerable to predation }\end{array}$ & Med & Direct, adverse & $\begin{array}{l}\text { No, effects } \\
\text { reasonably } \\
\text { described }\end{array}$ & $\begin{array}{l}\text { Limit construction to } \\
\text { daylight hours }\end{array}$ \\
\hline Hawaiian monk seal & $\begin{array}{l}\text { Decommissioning of } \\
\text { structures on water's } \\
\text { surface or seabed }\end{array}$ & $\begin{array}{l}\text { Decommissioning } \\
\text { of cables and } \\
\text { mooring }\end{array}$ & $\begin{array}{l}\text { Entanglement in debris } \\
\text { if not removed from } \\
\text { project area }\end{array}$ & High & Direct, adverse & $\begin{array}{l}\text { No, effects } \\
\text { reasonably } \\
\text { described }\end{array}$ & $\begin{array}{l}\text { Complete removal of } \\
\text { all cables and } \\
\text { moorings }\end{array}$ \\
\hline $\begin{array}{l}\text { Green sea turtles, } \\
\text { hawksbill sea turtles }\end{array}$ & $\begin{array}{l}\text { Decommissioning of } \\
\text { structures on water's } \\
\text { surface or seabed }\end{array}$ & $\begin{array}{l}\text { Seabed } \\
\text { disturbance }\end{array}$ & $\begin{array}{l}\text { Temporary loss of } \\
\text { foraging habitat }\end{array}$ & Med & Indirect, adverse & $\begin{array}{l}\text { No, effects } \\
\text { reasonably } \\
\text { described }\end{array}$ & $?$ \\
\hline
\end{tabular}




\subsubsection{Priority studies warranted for a small commercial Pelamis P-2 project at Makapu'u}

Our final analysis was to identify effects that are sufficiently high and uncertain to warrant further study (Table 24); we compiled and summarized possible future studies from the overall risk evaluation table.

Table 24 - Possible future studies warranted for small commercial scale Pelamis Wave Power P-2 project at Makapu'u site

\begin{tabular}{|c|c|c|}
\hline Indicator species or group & Potential Effect & Possible future studies \\
\hline $\begin{array}{l}\text { Bottomfishes; mahimahi and } \\
\text { scombrids; billfish; sharks }\end{array}$ & $\begin{array}{l}\text { Structure in water column acts } \\
\text { similarly to FAD, no effect on } \\
\text { seafloor structure }\end{array}$ & Use of structures could be measured \\
\hline Hawaiian monk seals & $\begin{array}{l}\text { Visual disorientation from lights } \\
\text { could lead to collision, but could } \\
\text { also enhance foraging on species } \\
\text { attracted to light }\end{array}$ & $\begin{array}{l}\text { Use of structures at night could be } \\
\text { measured }\end{array}$ \\
\hline $\begin{array}{l}\text { Bottomfishes; mahimahi, } \\
\text { scombrids }\end{array}$ & $\begin{array}{l}\text { Structure on water's surface acts as } \\
\text { FAD, changes in predator/prey } \\
\text { abundance, interactions }\end{array}$ & Use of structures could be measured \\
\hline $\begin{array}{l}\text { Albatrosses, shearwaters, and } \\
\text { storm-petrels }\end{array}$ & Collision with structures while flying & $\begin{array}{l}\text { Flight paths, heights, use of area, and } \\
\text { collision rates could be measured }\end{array}$ \\
\hline $\begin{array}{l}\text { Noddies and terns; great } \\
\text { frigatebirds, white-tailed } \\
\text { tropicbird, brown booby }\end{array}$ & $\begin{array}{l}\text { Attractant to birds due to } \\
\text { aggregated prey (FAD effect), } \\
\text { collision while flying }\end{array}$ & $\begin{array}{l}\text { Flight paths, heights, use of area, and } \\
\text { collision rates could be measured }\end{array}$ \\
\hline $\begin{array}{l}\text { Hawaiian monk seal; humpback } \\
\text { whales; noddies and terns; } \\
\text { green sea turtles, hawksbill sea } \\
\text { turtles }\end{array}$ & $\begin{array}{l}\text { Possible movement from area, } \\
\text { disruption of foraging, masks } \\
\text { environmental cues, song, } \\
\text { communication signals }\end{array}$ & $\begin{array}{l}\text { Device noise should be measured } \\
\text { and compared to noise effect } \\
\text { thresholds in the literature }\end{array}$ \\
\hline $\begin{array}{l}\text { All marine mammal indicators; } \\
\text { bottomfishes; mahimahi and } \\
\text { scombrids; sharks; green sea } \\
\text { turtles and hawksbill sea turtles }\end{array}$ & $\begin{array}{l}\text { Changes in orientation, behavior } \\
\text { due to EMF }\end{array}$ & $\begin{array}{l}\text { Effects literature is growing but no } \\
\text { consensus yet }\end{array}$ \\
\hline
\end{tabular}

\subsubsection{Application of a small commercial scale Pelamis Wave Power P-2 Project at Makapu'u to other Makapu'u scenarios}

The combination of 4 wave energy technologies and 3 project scales results in 12 Makapu'u scenarios. The detailed effects analysis was applied to the installation, operations and maintenance, and decommissioning of a small commercial Pelamis Wave Power P-2 project. We can extrapolate the risks identified in this scenario to the other scenarios by considering the similarities and differences in technologies, and in project scale. 
Boat traffic was identified as a project activity that posed a medium-high risk and exposure to some species of cetaceans, pinnipeds, and sea turtles in a small commercial scale Pelamis Wave Power P-2 project at Makapu'u. Risk and exposure due to boat traffic would be directly proportional to project scale; for example, pilot scale OPT Power Buoy and Aquamarine Power Oyster risks would be lower. The Wave Dragon pilot scale project is a single large device, rather than many smaller ones, so boat traffic would likely be less for the pilot scale Wave Dragon project compared to a small commercial scale Pelamis Wave Power P-2 project at Makapu'u. For all large commercial scale projects, we can assume that boat traffic effects will be greater than those identified in a small commercial scale Pelamis Wave Power P-2 project at Makapu'u. The Oyster technology, regardless of scale, may pose less boat traffic risk due to its location nearer to shore.

Construction and decommissioning activities were identified as posing high risk and exposure of noise, seabed disturbance, and navigation lights to some marine birds, sea turtles, and Hawaiian monk seals in a small commercial scale Pelamis Wave Power P-2 project at Makapu'u. Like boat traffic, these risks are also directly proportional to project scale, and with our current level of knowledge, we cannot assess whether some technologies will allow significantly less construction or decommissioning noise, seabed disturbance, or construction lighting than that anticipated in a small commercial scale Pelamis Wave Power P-2 project at Makapu'u.

Entanglement with lost fishing gear (NOAA 2009b) that becomes entangled with the moorings was identified as posing a high risk to humpback whales, Hawaiian monk seals, and sea turtles in a small commercial scale Pelamis Wave Power P-2 project at Makapu'u; these effects would increase with a greater number of moorings associated with project devices. For example, the Wave Dragon device has a single point mooring whereas Pelamis and the OPT Power Buoy technologies both have multiple moorings per device. Similarly, effects would increase with a greater number of devices associated with the larger-scale projects. The Oyster technology, regardless of scale, poses no entanglement risks because the device is anchored directly to the seabed.

The wave energy conversion devices in a small commercial scale Pelamis Wave Power P-2 project at Makapu'u were identified as posing an unknown collision risk to some marine birds; these effects would increase with an increasing height of the devices above the water's surface, a greater number of devices, and/or with an increasing footprint. The Pelamis technology would have a lesser height $(\sim 3 \mathrm{~m}$ above the surface, $180 \mathrm{~m}$ length per device) than the OPT ( $8 \mathrm{~m}$ above the surface, $11 \mathrm{~m}$ diameter per device) and 
Wave Dragon ( 7-10 $\mathrm{m}$ above the surface and 150-220 $\mathrm{m}$ length per device) technologies. The Wave Dragon technology has the greatest height of all the devices; however, it has fewer total devices and a smaller footprint. The OPT technology has the greatest number of devices and largest footprint, and is one of the taller devices; however, each device is much smaller in size than the other technologies. There is not enough information to determine the effect of height, footprint, or number of devices on collision risk. The Oyster technology, due to its minimal surface structure, would be expected to cause little to no collision risk to marine birds.

Artificial reef and FAD effects could change predator and prey relationships, and increase exposure to lost gear entanglement for a small commercial scale Pelamis Wave Power P-2 project at Makapu'u; these effects may vary depending on technology. For example, the Wave Dragon technology may have a greater FAD effect due to its configuration as a larger unit given the same energy output. The Wave Dragon technology may present differences in effects due to moorings; it may require less structure in the water column than the Pelamis or Power Buoy technologies, presenting fewer artificial reef effects. The Oyster technology, due to its lack of surface structure, would be expected to cause minimal FAD effects but could cause artificial reef effects.

Navigation lights on the wave devices in a small commercial scale Pelamis Wave Power P-2 project at Makapu'u were identified as posing a high risk to some marine birds and sea turtles; these effects would increase with a greater number of lights and/or an increased spatial footprint of the lights. The Wave Dragon technology would have a smaller light effect because it is a single device that may require fewer lights. The Oyster technology would presumably require navigation lights even thought it is inshore; therefore, this structure would also be expected to pose navigation light effects.

For the small commercial scale Pelamis Wave Power P-2 project at Makapu'u, we determined that EMF effects remain unknown despite growing literature. EMF effects would also be project scale dependent, similar to boat traffic and noise effects discussed above. However, the Oyster technology is notable because it would produce no EMF in the marine environment.

The noise characteristics produced by the devices are unknown, but likely varies among all of the technologies. Amplitude and frequency of noise emitted by devices could vary significantly by technology and scale; a device's amplitude determines the noise propagation, or how far the sound travels, and its frequency determines the marine mammal species that can detect or are affected by the noise. At this time, we have no basis for assessing the noise characteristics among technologies, or for 
comparing the effects of the noise produced by different types of devices or at different scales on marine mammals.

Effects to the physical environment, including water quality, sediment transport, and wave energy are scale-dependent. However, because the Oyster and Wave Dragon technologies do not use hydraulic fluids, they present no potential effect to water quality associated with hydraulic fluid seepage or spills. The inshore deployment of the Oyster technology is likely to have greater effects on wave energy dynamics and coral reefs, particularly at the commercial scale. 


\section{Environmental Effects Analysis: Tidal Projects}

An environmental effects analysis was conducted on 1 tidal scenario; a pilot scale MCT SeaGen project at Tacoma Narrows, Washington. The criteria for selecting this project over other tidal energy project scenarios included:

- Technology representing tidal energy conversion

- Project scale variation

- Data readily available from technology developers

- Degree of technology development

- Degree of uncertainty in environmental effects

The latter 3 criteria in the list above did not support evaluating a large commercial scale scenario. The degree of uncertainty in technology development and environmental effects, and the lack of readily available data from large commercial scale projects, were high enough that an evaluation would have been premature.

\subsection{Summary Description of Tidal Energy Technologies}

Tidal power remains at an early stage of development. As such, a wide range of different technologies are being pursued by different manufacturers. In order to properly characterize impacts, it is useful to characterize the range of technologies that could be deployed at the site of interest. An industry survey informs the process of selecting representative tidal power devices. The selection criteria are that such devices are at an advanced stage of development to reduce technical uncertainties and that enough data are available from the manufacturers to inform the conceptual design process of this study. Further, an attempt is made to cover the range of different technologies under development to capture variations in potential environmental effects. Table 25 summarizes the selected tidal power technologies. A number of other developers are also at an advanced stage of development including Verdant Power, which has demonstrated an array of turbines in the East River of New York, Clean Current, which has demonstrated a device off Race Rocks, BC, and OpenHydro, which has demonstrated a device at the European Marine Energy Test Center and recently deployed a larger device in the Bay of Fundy. 
Table 25 - Selected tidal power technologies

\begin{tabular}{|l|l|l|l|}
\hline \multicolumn{2}{|c|}{$\begin{array}{c}\text { Marine Current Turbines } \\
\text { SeaGen }\end{array}$} & \multicolumn{2}{c|}{ Lunar Energy RTT } \\
\hline \multirow{2}{*}{ Rotor } & $\begin{array}{l}\text { Dual rotor, horizontal axis: } \\
\text { variable pitch aerofoil } \\
\text { Power train }\end{array}$ & $\begin{array}{l}\text { Horizontal axis: fixed pitch, } \\
\text { symetric aerofoil } \\
\text { Ducted }\end{array}$ & $\begin{array}{l}\text { Dual rotor, horizontal axis: } \\
\text { fixed pitch, } \\
\text { asymmetric } \\
\text { aerofoil }\end{array}$ \\
\hline Mooring & Gearbox speed increaser & Hydraulic & Gearbox speed increaser \\
\hline Foundation & Rigid: pile & Rigid: tubular truss & Compliant: cable \\
\hline
\end{tabular}

\subsection{Site Description: Tacoma Narrows, Washington}

Tacoma Narrows is located in Puget Sound, approximately eight miles west of the city of Tacoma (Figure 5). Much of the Puget Sound to the north and south of the Narrows is quite deep and wide (e.g., 230m deep and 6500m wide between Vashon Island and the mainland); however, Tacoma Narrows is relatively shallow $(40-80 \mathrm{~m})$ and narrow $(\sim 1500 \mathrm{~m})$. As a result, the twice-daily tidal exchange generates high velocities as water moves through the constriction. The project site is located in an industrial area and close to the Port of Tacoma. The seabed is composed of dense sand and gravel. There are numerous species that occur in the Tacoma Narrows marine environment that could be affected by the project, these include:

- Whales, 15 species

- Pinnipeds, 6 species

- Elasmobranchs (sharks, skates, rays), over 15 species

- Salmon, rockfishes, and flatfishes

- Marine birds, over 60 species

Some of these species are listed by state and federal agencies as species of concern, threatened, or endangered. Some are important commercial species. 


\section{Pevision}

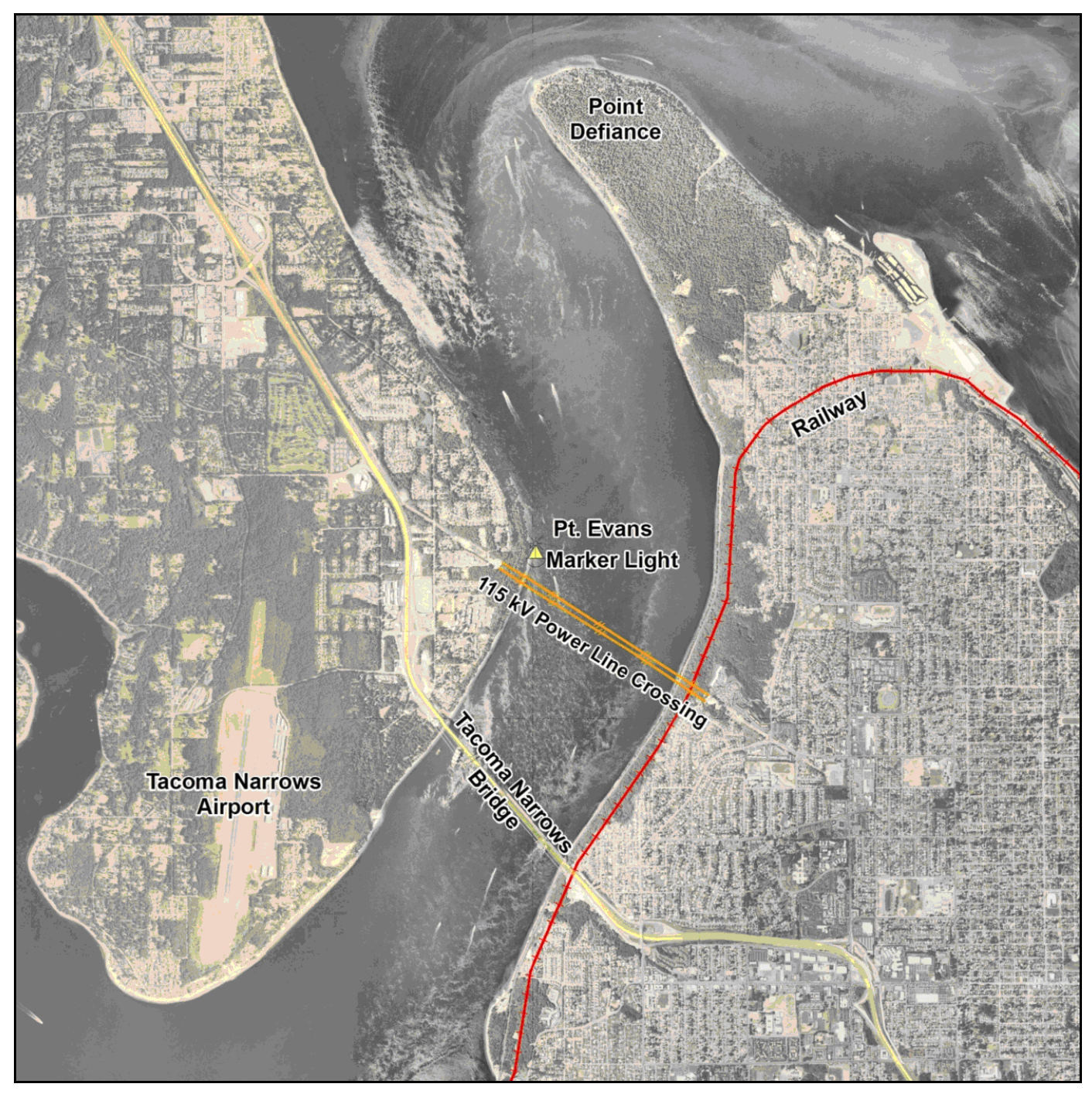

Figure 5 - Tacoma Narrows Overview Map

\subsection{Environmental Effects Analysis: Pilot scale MCT SeaGen project at Tacoma Narrows}

Details of this scenario are presented in report \#3, Tidal Energy Scenarios. Table 26 shows key technical attributes and Figure 6 is an overview map showing the likely footprint of the tidal array at the deployment site. 
Table 26 - MCT scenario attributes

\begin{tabular}{|c|c|}
\hline $\begin{array}{l}\text { Scale } \\
\text { Scenario Index }\end{array}$ & $\begin{array}{c}\text { Pilot } \\
1\end{array}$ \\
\hline \multicolumn{2}{|l|}{ Device } \\
\hline Rated electrical power (kW) & 1173 \\
\hline Average electrical power (kW) & 354 \\
\hline Rotor & Dual 20 m diameter, horizontal axis \\
\hline Foundation type & Penetrating pile \\
\hline Total device weight & 394 tonnes \\
\hline \multicolumn{2}{|l|}{ Operational Considerations } \\
\hline Installation time & 1 month \\
\hline Decommissioning time & $<1$ month \\
\hline Planned operational interventions per year & $<2$ \\
\hline Project life & $>20$ years \\
\hline \multicolumn{2}{|l|}{ Site } \\
\hline Seabed composition & Cobbles and consolidated sediments \\
\hline Kinetic power density $\left(\mathrm{kW} / \mathrm{m}^{2}\right)^{7}$ & 1.6 \\
\hline \multicolumn{2}{|l|}{ Array Performance } \\
\hline Number of devices & 1 \\
\hline Average electrical power (MW) & 0.4 \\
\hline Rated electrical power (MW) & 1.2 \\
\hline Capacity factor & $30 \%$ \\
\hline Average deployment depth (m) & 44.4 \\
\hline Average hub height $(\mathrm{m})$ & 29.4 \\
\hline \multicolumn{2}{|l|}{ Array Environmental Footprint } \\
\hline Volume of lubricant $(\mathrm{L})$ & 110 \\
\hline Physical footprint on seabed $\left(\mathrm{m}^{2}\right)$ & 7 \\
\hline Permanent hard substrate $\left(\mathrm{m}^{\llcorner}\right)$ & 280 \\
\hline Average blockage ratio & $1 \%$ \\
\hline$\%$ of time operating & $70 \%$ \\
\hline \% transport reduction in South Sound & $0.0 \%$ \\
\hline Navigation Considerations & $\begin{array}{c}\text { Surface piercing: Lighted, painted pile w/ } \\
\text { surrounding safety zone }\end{array}$ \\
\hline
\end{tabular}

${ }^{1}$ Kinetic power density is baseline average for locations occupied by turbines 


\section{re vision}

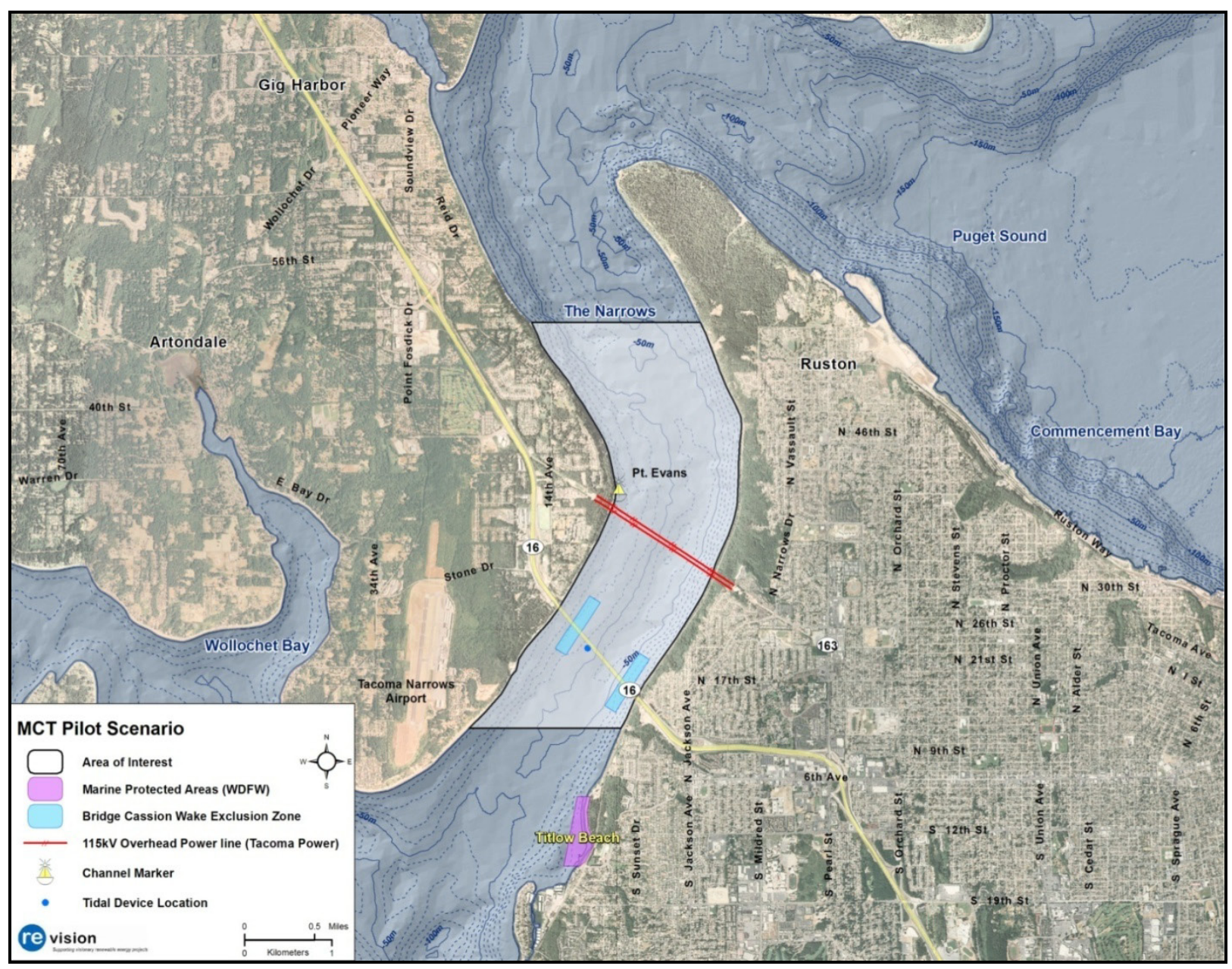

Figure 6 - MCT pilot array layout

Potential effects on indicator species and groups, and on physical site attributes, were assessed using the biological, physical, and evaluation tables (Table 4, Table 5, and Table 6 of Section 3.4). This tabular approach generated numerous and large tables, which are presented in appendices. This tidal scenario was selected because it represents a project that could realistically be constructed in the near future. We also compared the environmental effects analysis conducted for the pilot scale MCT SeaGen project to the other project scenarios at Tacoma Narrows.

\subsubsection{Potential effects of project on physical site characteristics}

Effects of the project on physical attributes, including water quality, sediment transport, and tidal dynamics are anticipated to be minimal and potentially immeasurable at the pilot project scale. Boats used for construction and operations and maintenance may release small amounts of oils and other chemicals but it is likely these will be in extremely small amounts. Seabed disturbance associated with project 
construction, including directional drilling for laying cable, is also likely to be temporary and spatially minimal due to the consolidated, scoured substrate. Structure on the bottom is also considered to have low impacts to sediment transport and tidal dynamics due to the small scale of the project. The effects of project actions on physical site characteristics are detailed in Appendix F, and all effects rated with a medium, high, or unknown risk to the indicator are detailed in Table 30.

\subsubsection{Exposure of pinnipeds and cetaceans to project}

Cetacean and pinniped indicator species were selected for the Tacoma Narrows tidal energy project environmental effects analysis using the same indicator selection process as was detailed for the Humboldt wave energy project (Appendix D); this approach considered the temporal distribution, habitat, and abundance for all pinnipeds and cetacean species that could occur in the project area. The following cetacean and pinniped species were selected as indicator species to assess the effects of a Tacoma Narrows tidal energy project: 1) Northern sea lion; 2) harbor seal; 3) gray whale; 4) killer whale; and 5) harbor porpoise and Dall's porpoise. For each indicator, the spatial and temporal exposure of project actions to the indicator was determined, and the overlap of the project actions' potential effects with the indicator's critical life stage, behavior, or resource was evaluated ("exposure"). The exposure to cetacean and pinniped indicators as a result of project actions is detailed in Appendix F and summarized in Table 27.

Table 27 - Summary of exposure (medium, high, unknown) of cetaceans and pinnipeds to a pilot scale MCT SeaGen project at Tacoma Narrows.

\begin{tabular}{|c|c|c|}
\hline Indicator & $\begin{array}{l}\text { Degree of } \\
\text { overlap with } \\
\text { project actions }\end{array}$ & Action and potential effect \\
\hline Northern sea lion, harbor seal & Medium & $\begin{array}{l}\text { Noise and vibration from boats, construction and/or noise } \\
\text { emitted from tidal energy devices resulting in avoidance or } \\
\text { masking communication and environmental cues }\end{array}$ \\
\hline Northern sea lion, harbor seal & Medium & $\begin{array}{l}\text { Direct impact (collision injuries) with boats associated with } \\
\text { construction, maintenance, and decommissioning activities }\end{array}$ \\
\hline All & Medium & Direct impact (collision injuries) with rotors on device \\
\hline $\begin{array}{l}\text { Northern sea lion, harbor seal, } \\
\text { harbor porpoise and Dall's } \\
\text { porpoise }\end{array}$ & Medium & Entanglement with lost fishing gear caught on devices \\
\hline All & Unknown & $\begin{array}{l}\text { Operation of devices creating noise that could cause } \\
\text { behavioral changes in species }\end{array}$ \\
\hline All & Unknown & Disorientation or behavioral changes from EMF \\
\hline
\end{tabular}




\subsubsection{Exposure of fish to project}

Fish indicator species were selected for the Tacoma Narrows tidal energy project environmental effects analysis using the same indicator selection process as was detailed for the Humboldt wave energy project (Appendix D); this approach considered if fish species are known to occur in Puget Sound waters, if suitable habitat either occurs in the project area or would be created by the project, and if aspects of their behavior and/or biology would makes it likely that they would be affected by the project. Fish species were also selected if the project area is located within designated Essential Fish Habitat (EFH), and/or if they are designated as federally threatened or endangered and could occur in the project area. The following indicator species groups were selected for the Tacoma Narrows tidal energy project effects analysis: 1) sharks, skates, and rays (elasmobranchs); 2) flatfishes; 3) rockfish, cabezon, and lingcod; 4) forage fishes (including smelts); and 5) juvenile salmonids; and 6) adult salmonids. Several species of salmonids are listed as federally threatened or endangered. For each indicator, the spatial and temporal exposure of project actions to the indicator was determined, and the overlap of the project actions' potential effects with the indicator's critical life stage, behavior, or resource was evaluated ("exposure"). The exposure to fish indicators as a result of project actions is detailed in Appendix F and summarized in Table 28.

Table 28 - Summary of exposure to a pilot scale MCT SeaGen project at Tacoma Narrows with a med, high, or unknown overlap with fish indicators from the effects analysis tables.

\begin{tabular}{|c|c|c|}
\hline Indicator & $\begin{array}{l}\text { Degree of } \\
\text { overlap with } \\
\text { project actions }\end{array}$ & Action and potential effect \\
\hline Forage fishes & High & $\begin{array}{l}\text { Toxicity at nearby spawning beaches from oil/chemical } \\
\text { releases from boats, construction activities, or emitted from } \\
\text { devices }\end{array}$ \\
\hline Sharks and juvenile salmonids & Medium & $\begin{array}{l}\text { Aggregation or behavioral changes from construction and } \\
\text { decommissioning lights, and/or navigation lights on } \\
\text { devices, resulting in increased vulnerability to predation on } \\
\text { juvenile salmonids by sharks or other predators }\end{array}$ \\
\hline $\begin{array}{l}\text { Sharks, forage fishes, juvenile } \\
\text { salmonids }\end{array}$ & Medium & Collision with moving turbines \\
\hline $\begin{array}{l}\text { Sharks, skates, and rays, } \\
\text { juvenile and adult salmonids, } \\
\text { flatfishes }\end{array}$ & Unknown & Disorientation or behavioral changes from EMF \\
\hline $\begin{array}{l}\text { Sharks, juvenile and adult } \\
\text { salmonids }\end{array}$ & Unknown & $\begin{array}{l}\text { Fish aggregation device from structures on water's surface } \\
\text { which could attract sharks and increase predation on } \\
\text { salmonids; harbor seals could also haul-out on structures } \\
\text { and attract sharks and/or prey on salmonids }\end{array}$ \\
\hline
\end{tabular}




\begin{tabular}{|l|l|l|}
\hline $\begin{array}{l}\text { Flatfishes, juvenile and adult } \\
\text { salmonids }\end{array}$ & Unknown & $\begin{array}{l}\text { Reef effect created by structures resulting in attraction of } \\
\text { predators, changes in predator/prey interactions }\end{array}$ \\
\hline Rockfish, cabezon, and lingcod & Medium & $\begin{array}{l}\text { Attraction to artificial reef created by structures in water } \\
\text { column and seabed resulting in changes in fish community } \\
\text { composition }\end{array}$ \\
\hline Rockfish, cabezon, and lingcod & Unknown & Noise emitted from devices resulting in altered behavior \\
\hline
\end{tabular}

\subsubsection{Exposure of marine birds to project}

Marine bird indicators were selected for the Tacoma Narrows tidal energy project effects analysis using the same indicator selection process as was detailed for the Humboldt wave energy project (Appendix D); this approach determined the foraging mode, foraging habitat and diurnal rhythms of all marine bird species that could occur in the project area. The following species or species groups were selected as indicators: 1) diving ducks, loons and grebes; 2) gulls; 3) cormorants; 4) alcids, including the federally threatened marbled murrelet. For each indicator, the spatial and temporal exposure of project actions to the indicator was determined, and the overlap of the project actions' potential effects with the indicator's critical life stage, behavior, or resource was evaluated ("exposure"). The exposure to marine bird indicators as a result of project actions is detailed in Appendix F and summarized in Table 29.

Table 29 - Summary of exposure (medium, high, unknown) of marine bird indicators to a pilot scale MCT SeaGen project at Tacoma Narrows.

\begin{tabular}{|c|c|c|}
\hline Indicator & $\begin{array}{l}\text { Degree of } \\
\text { overlap with } \\
\text { project actions }\end{array}$ & Action and potential effect \\
\hline $\begin{array}{l}\text { Diving ducks, loons, } \\
\text { grebes, cormorants, alcids }\end{array}$ & Medium & $\begin{array}{l}\text { Avoidance of area, disruption of foraging from noise emitted from } \\
\text { boats associated with construction, maintenance, and } \\
\text { decommissioning activities }\end{array}$ \\
\hline $\begin{array}{l}\text { Diving ducks, loons, } \\
\text { grebes, gulls, cormorants, } \\
\text { alcids }\end{array}$ & Medium & $\begin{array}{l}\text { Toxicity from potential oil/chemical releases from boats, } \\
\text { construction activities, or emitted from devices }\end{array}$ \\
\hline $\begin{array}{l}\text { Diving ducks, loons, and } \\
\text { grebes }\end{array}$ & Medium & $\begin{array}{l}\text { Disruption of foraging and short-term changes in food resources } \\
\text { from seabed disturbance and noise and vibration associated with } \\
\text { construction, directional drilling, or decommissioning }\end{array}$ \\
\hline Alcids & Medium & Attraction to and/or disorientation with lights on devices \\
\hline $\begin{array}{l}\text { Diving ducks, loons, } \\
\text { grebes, cormorants, alcids }\end{array}$ & Medium & Collision with moving turbines while diving \\
\hline $\begin{array}{l}\text { Diving ducks, loons, and } \\
\text { grebes }\end{array}$ & Medium & $\begin{array}{l}\text { Avoidance of area, disruption of foraging from noise emitted from } \\
\text { devices }\end{array}$ \\
\hline
\end{tabular}




\begin{tabular}{|l|l|l|}
\hline $\begin{array}{l}\text { Diving ducks, loons, and } \\
\text { grebes, and cormorants }\end{array}$ & Medium & $\begin{array}{l}\text { Attraction to aggregated prey at underwater structures (reef } \\
\text { effect), entanglement with lost fishing gear if it becomes tangled } \\
\text { with underwater mooring lines/structures }\end{array}$ \\
\hline $\begin{array}{l}\text { Diving ducks, loons, } \\
\text { grebes, gulls, cormorants, } \\
\text { alcids }\end{array}$ & Medium & $\begin{array}{l}\text { Attraction to aggregated prey at structures on the water's surface } \\
\text { (FAD effect) which could increase predation on other species } \\
\text { (i.e., salmon), roosting on structures (for gulls and cormorants), } \\
\text { and/or collision with devices while flying }\end{array}$ \\
\hline
\end{tabular}

\subsection{Overall risk to indicators for a pilot scale MCT SeaGen project at Tacoma Narrows}

Once the exposure of indicators to project actions was determined based on the overlap with spatial, temporal, and critical life stages (see previous sections and Appendix F), we assessed the overall risk of project actions to the indicators based on the potential for effects to occur. We summarized all indicators/effects that had a medium, high, or unknown risk (Table 30 and Table 31).

No project activities pose high risks to site physical characteristics (Table 30). Low risks are determined for all project activities to tidal dynamics, sediment transport and water chemistry. Activities that may pose medium risks to site physical characteristics include:

- Boat traffic and project construction and decommissioning, which could cause temporary noise and vibration in the acoustic environment

- Construction and decommissioning lights, which would cause temporary effects in the visual environment

- Presence of device structures above the water surface that are visible from shore

- Noise emitted from the tidal energy devices

Project activities that may pose medium or high risks to biological indicators are (Table 31):

- Boat traffic during all project phases, resulting in potential collision effects on Northern sea lions

- Construction and deck lights used in construction and decommissioning, and/or navigation lights on devices, causing disorientation, aggregation, and/or increased vulnerability to predation for alcids and juvenile salmonids

- Underwater devices attracting rockfishes

- Collision with underwater moving turbines for all marine mammal indicators and some fishes 
Project activities that pose unknown risks to biological indicators are (Table 31):

- Surface and/or underwater structures could attract flatfishes and salmonids due to reef and fish aggregating device (FAD) effects and result in changes to predator/prey relationships, and/or species composition

- Surface structures could result in FAD effects, provide haul-out structure for pinnipeds, attract sharks, and result in increased predation on listed fish species (i.e., salmonids)

- Underwater structures could become entangled with lost fishing gear and cause marine mammals and/or marine birds to become entangled while diving, prey aggregation (reef effects) at structures could attract these species and increase entanglement risks

- Surface structures could provide roosting habitat and/or attract species due to prey aggregations (FAD effects), and increase collision risks for diving ducks, loons, grebes, gulls, cormorants, and alcids

- Underwater turbines could pose collision risks to sharks; diving ducks, loons, grebes, alcids, and cormorants

- Navigation lights on devices could attract sharks due to prey aggregations

- Generation of EMF could cause changes in orientation and behavior in sharks, skates, rays, juvenile and adult salmonids, and all marine mammal indicators

We note that mitigation measures are known for most of these high and unknown effects. This study did not evaluate the effectiveness of mitigation measures, and whether mitigation could reduce risk to less than significant levels. 
Table 30 - Overall risk (medium, high, unknown) to site physical characteristics for a pilot scale MCT SeaGen project at the Tacoma Narrows.

\begin{tabular}{|c|c|c|c|c|c|c|c|}
\hline Indicator & Project activity & Project action & $\begin{array}{l}\text { Description of action's } \\
\text { effect on indicator } \\
\text { species }\end{array}$ & $\begin{array}{l}\text { Overall risk to } \\
\text { indicator (med, } \\
\text { high, unknown) }\end{array}$ & $\begin{array}{l}\text { Effect type } \\
\text { (in/direct, } \\
\text { beneficial, } \\
\text { neutral, } \\
\text { adverse) }\end{array}$ & $\begin{array}{c}\text { Uncertainty } \\
\text { warrants } \\
\text { further study? }\end{array}$ & $\begin{array}{l}\text { Potential } \\
\text { mitigation }\end{array}$ \\
\hline \multicolumn{8}{|c|}{ Construction } \\
\hline $\begin{array}{l}\text { Acoustic } \\
\text { environment }\end{array}$ & \begin{tabular}{|l|} 
Construction of electrical \\
collector system, moorings \\
and foundations, and \\
device installation
\end{tabular} & $\begin{array}{l}\text { Noise and } \\
\text { vibration }\end{array}$ & $\begin{array}{l}\text { Adds to existing natural and } \\
\text { man-made noise in project } \\
\text { area }\end{array}$ & $\begin{array}{l}\text { Med, noise elevated } \\
\text { but short-term, pre- } \\
\text { existing noise } \\
\text { ameliorates effect }\end{array}$ & Direct, adverse & $\begin{array}{l}\text { No, effects } \\
\text { reasonably } \\
\text { described }\end{array}$ & Minimize duration \\
\hline $\begin{array}{l}\text { Visual } \\
\text { environment }\end{array}$ & $\begin{array}{l}\text { Construction of electrical } \\
\text { collector system, moorings } \\
\text { and foundations; device } \\
\text { installation }\end{array}$ & $\begin{array}{l}\text { Construction } \\
\text { and deck lights }\end{array}$ & $\begin{array}{l}\text { Construction lights much } \\
\text { brighter than vessel lights, will } \\
\text { be visible from shore }\end{array}$ & $\begin{array}{l}\text { Med, lights will be } \\
\text { visible from shore but } \\
\text { location in industrial/ } \\
\text { urban area } \\
\text { ameliorates effect }\end{array}$ & Direct, adverse & $\begin{array}{l}\text { No, effects } \\
\text { reasonably } \\
\text { described }\end{array}$ & $\begin{array}{l}\text { Limit construction } \\
\text { to daylight hrs }\end{array}$ \\
\hline \multicolumn{8}{|c|}{ Operation and Maintenance } \\
\hline $\begin{array}{l}\text { Acoustic } \\
\text { environment }\end{array}$ & $\begin{array}{l}\text { Operation of turbines or } \\
\text { other moving parts of } \\
\text { devices }\end{array}$ & $\begin{array}{l}\text { Noise and } \\
\text { vibration }\end{array}$ & $\begin{array}{l}\text { Adds to existing natural and } \\
\text { man-made noise in project } \\
\text { area }\end{array}$ & Unknown & $\begin{array}{l}\text { Potentially } \\
\text { direct and } \\
\text { adverse }\end{array}$ & $\begin{array}{l}\text { Yes, study } \\
\text { warranted }\end{array}$ & Unknown \\
\hline $\begin{array}{l}\text { Visual } \\
\text { environment }\end{array}$ & $\begin{array}{l}\text { Structures on water's } \\
\text { surface }\end{array}$ & Structure & $\begin{array}{l}\text { Structure } 8 \mathrm{~m} \text { above water's } \\
\text { surface }\end{array}$ & $\begin{array}{l}\text { Med, device profiles } \\
\text { low and "facilities will } \\
\text { probably have little } \\
\text { visual impact" (NOAA } \\
2007 \text { ) }\end{array}$ & Direct, adverse & $\begin{array}{l}\text { Yes, could } \\
\text { evaluate } \\
\text { potential } \\
\text { visibility from } \\
\text { shore }\end{array}$ & $\begin{array}{l}\text { Minimize device } \\
\text { profiles }\end{array}$ \\
\hline \multicolumn{8}{|c|}{ Decommissioning } \\
\hline $\begin{array}{l}\text { Acoustic } \\
\text { environment }\end{array}$ & $\begin{array}{l}\text { Decommissioning of } \\
\text { structures on water's } \\
\text { surface or seabed }\end{array}$ & $\begin{array}{l}\text { Noise and } \\
\text { vibration }\end{array}$ & $\begin{array}{l}\text { Adds to existing natural and } \\
\text { man-made noise in project } \\
\text { area }\end{array}$ & $\begin{array}{l}\text { Med, noise elevated } \\
\text { but short-term, pre- } \\
\text { existing noise } \\
\text { ameliorates effect }\end{array}$ & Direct, adverse & $\begin{array}{l}\text { No, effects } \\
\text { reasonably } \\
\text { described }\end{array}$ & $\begin{array}{l}\text { Need for } \\
\text { mitigation not } \\
\text { established }\end{array}$ \\
\hline $\begin{array}{l}\text { Visual } \\
\text { environment }\end{array}$ & $\begin{array}{l}\text { Decommissioning of } \\
\text { structures on water's } \\
\text { surface or seabed }\end{array}$ & $\begin{array}{l}\text { Deconstruction } \\
\text { and deck lights }\end{array}$ & $\begin{array}{l}\text { Deconstruction lights much } \\
\text { brighter than vessel lights, will } \\
\text { be visible from shore. }\end{array}$ & $\begin{array}{l}\text { Med, lights will be } \\
\text { visible from shore but } \\
\text { location in industrial/ } \\
\text { urban area } \\
\text { ameliorates effect }\end{array}$ & Direct, adverse & $\begin{array}{l}\text { No, effects } \\
\text { reasonably } \\
\text { described }\end{array}$ & $\begin{array}{l}\text { Limit } \\
\text { deconstruction to } \\
\text { daylight hours }\end{array}$ \\
\hline
\end{tabular}


Table 31 - Overall risk (medium, high, unknown) to indicator species or species groups for a pilot scale MCT SeaGen project at the Tacoma Narrows.

\begin{tabular}{|c|c|c|c|c|c|c|c|}
\hline Indicator & Project activity & Project action & $\begin{array}{l}\text { Description of action's } \\
\text { effect on indicator species }\end{array}$ & $\begin{array}{l}\text { Overall risk to } \\
\text { indicator } \\
\text { (med, high, } \\
\text { unknown) }\end{array}$ & $\begin{array}{l}\text { Effect type } \\
\text { (in/direct, } \\
\text { beneficial, } \\
\text { neutral, } \\
\text { adverse) }\end{array}$ & $\begin{array}{l}\text { Uncertainty } \\
\text { warrants further } \\
\text { study? }\end{array}$ & Potential mitigation \\
\hline \multicolumn{8}{|c|}{ Construction } \\
\hline Northern sea lion & Boat traffic & Direct impact & Collision injuries & Med & $\begin{array}{l}\text { Direct and } \\
\text { adverse }\end{array}$ & $\begin{array}{l}\text { No, effects } \\
\text { reasonably described }\end{array}$ & Vessel speed limits \\
\hline $\begin{array}{l}\text { Juvenile } \\
\text { salmonids }\end{array}$ & $\begin{array}{l}\text { Construction of } \\
\text { electrical collector } \\
\text { system, moorings and } \\
\text { foundations, and } \\
\text { device installation }\end{array}$ & $\begin{array}{l}\text { Construction \& } \\
\text { deck lights }\end{array}$ & $\begin{array}{l}\text { Behavioral changes, more } \\
\text { vulnerable to predation }\end{array}$ & $\begin{array}{l}\text { Med, species } \\
\text { listed so take } \\
\text { prohibited }\end{array}$ & $\begin{array}{l}\text { Direct and } \\
\text { adverse }\end{array}$ & $\begin{array}{l}\text { No, effects } \\
\text { reasonably described }\end{array}$ & $\begin{array}{l}\text { Limit construction to } \\
\text { daylight hours }\end{array}$ \\
\hline \multicolumn{8}{|c|}{ Operation and Maintenance } \\
\hline $\begin{array}{l}\text { Diving ducks, } \\
\text { loons, grebes; } \\
\text { gulls, cormorants, } \\
\text { alcids }\end{array}$ & $\begin{array}{l}\text { Structures on water's } \\
\text { surface }\end{array}$ & Structure & $\begin{array}{l}\text { Attraction to increased prey } \\
\text { (FAD effect) which could } \\
\text { increase predation on other } \\
\text { species (i.e., salmon), } \\
\text { collision while flying, roosting } \\
\text { (gulls and cormorants only) }\end{array}$ & Unknown & $\begin{array}{l}\text { Direct and } \\
\text { indirect, } \\
\text { beneficial and } \\
\text { adverse }\end{array}$ & $\begin{array}{l}\text { Yes, uncertain if } \\
\text { collision will occur or } \\
\text { if predation on other } \\
\text { species will increase }\end{array}$ & $\begin{array}{l}\text { Minimize height of } \\
\text { structure above } \\
\text { water's surface, } \\
\text { design devices to } \\
\text { prevent roosting }\end{array}$ \\
\hline Alcids & $\begin{array}{l}\text { Structures on water's } \\
\text { surface }\end{array}$ & $\begin{array}{l}\text { Navigation } \\
\text { lights }\end{array}$ & Attraction/ disorientation & Med & $\begin{array}{l}\text { Direct and } \\
\text { adverse }\end{array}$ & $\begin{array}{l}\text { No, effects } \\
\text { reasonably described }\end{array}$ & $\begin{array}{l}\text { Minimize and shield } \\
\text { lighting }\end{array}$ \\
\hline Sharks & $\begin{array}{l}\text { Structures on water's } \\
\text { surface }\end{array}$ & Structure & $\begin{array}{l}\text { Could attract prey (FAD } \\
\text { effect) and/or pinniped haul- } \\
\text { out and attract sharks }\end{array}$ & Unknown & $\begin{array}{l}\text { Indirect and } \\
\text { beneficial }\end{array}$ & $\begin{array}{l}\text { No, effects } \\
\text { reasonably described }\end{array}$ & $\begin{array}{l}\text { Design structures to } \\
\text { prevent haul-out by } \\
\text { pinnipeds to prevent } \\
\text { sharks congregating }\end{array}$ \\
\hline
\end{tabular}


revision

\begin{tabular}{|c|c|c|c|c|c|c|c|}
\hline Sharks & $\begin{array}{l}\text { Structures on water's } \\
\text { surface }\end{array}$ & $\begin{array}{l}\text { Navigation } \\
\text { lights }\end{array}$ & $\begin{array}{l}\text { Sharks may be attracted due } \\
\text { to prey aggregation }\end{array}$ & Unknown & $\begin{array}{l}\text { Direct and } \\
\text { beneficial }\end{array}$ & $\begin{array}{l}\text { No, effects } \\
\text { reasonably described }\end{array}$ & $\begin{array}{l}\text { Minimize and shield } \\
\text { lighting }\end{array}$ \\
\hline $\begin{array}{l}\text { Rockfish, lingcod, } \\
\text { cabezon, juvenile } \\
\text { \& adult salmonids }\end{array}$ & $\begin{array}{l}\text { Structures on water's } \\
\text { surface }\end{array}$ & Structure & $\begin{array}{l}\text { Possible FAD effect, } \\
\text { attraction of predators (e.g., } \\
\text { sharks, pinnipeds) }\end{array}$ & Unknown & $\begin{array}{l}\text { Indirect and } \\
\text { adverse }\end{array}$ & $\begin{array}{l}\text { Yes, uncertain if } \\
\text { these species } \\
\text { attracted to structure }\end{array}$ & $\begin{array}{l}\text { Design structures to } \\
\text { prevent haul-out by } \\
\text { pinnipeds }\end{array}$ \\
\hline $\begin{array}{l}\text { Juvenile } \\
\text { salmonids }\end{array}$ & $\begin{array}{l}\text { Structures on water's } \\
\text { surface }\end{array}$ & $\begin{array}{l}\text { Navigation } \\
\text { lights }\end{array}$ & $\begin{array}{l}\text { Behavioral changes, more } \\
\text { vulnerable to predation (e.g., } \\
\text { sharks }\end{array}$ & Med & $\begin{array}{l}\text { Indirect and } \\
\text { adverse }\end{array}$ & $\begin{array}{l}\text { Yes, uncertain if } \\
\text { juvenile salmon } \\
\text { attracted to light }\end{array}$ & $\begin{array}{l}\text { Minimize and shield } \\
\text { lighting }\end{array}$ \\
\hline $\begin{array}{l}\text { Diving ducks, } \\
\text { loons, grebes, } \\
\text { cormorants, alcids, } \\
\text { all marine } \\
\text { mammal indicators }\end{array}$ & $\begin{array}{l}\text { Structures in water } \\
\text { column and on } \\
\text { seabed }\end{array}$ & Structure & $\begin{array}{l}\text { Possible attraction to } \\
\text { increased prey (reef effect), } \\
\text { and/or entanglement with } \\
\text { lost fishing gear }\end{array}$ & Unknown & $\begin{array}{l}\text { Direct and } \\
\text { indirect, } \\
\text { beneficial and } \\
\text { adverse }\end{array}$ & $\begin{array}{l}\text { Yes, uncertain if } \\
\text { attraction or } \\
\text { entanglement will } \\
\text { occur }\end{array}$ & $\begin{array}{l}\text { Anti-fouling paint to } \\
\text { prevent invert. } \\
\text { attachment; } \\
\text { monitoring and } \\
\text { removal of gear }\end{array}$ \\
\hline $\begin{array}{l}\text { Flatfishes, } \\
\text { juvenile and adult } \\
\text { salmonids }\end{array}$ & $\begin{array}{l}\text { Structures in water } \\
\text { column and on } \\
\text { seabed }\end{array}$ & Structure & $\begin{array}{l}\text { Possible reef effect, } \\
\text { attraction of predators (e.g., } \\
\text { rockfish), changes in } \\
\text { predator/prey interactions }\end{array}$ & Unknown & $\begin{array}{l}\text { Indirect and } \\
\text { adverse }\end{array}$ & $\begin{array}{l}\text { Yes, uncertain if } \\
\text { predators are } \\
\text { attracted and if it will } \\
\text { affect these species }\end{array}$ & $?$ \\
\hline $\begin{array}{l}\text { Rockfish, lingcod, } \\
\text { cabezon }\end{array}$ & $\begin{array}{l}\text { Structures in water } \\
\text { column and on } \\
\text { seabed }\end{array}$ & Structure & $\begin{array}{l}\text { Attraction to artificial reef, } \\
\text { changes in fish community }\end{array}$ & Med & $\begin{array}{l}\text { Indirect and } \\
\text { potentially } \\
\text { beneficial }\end{array}$ & $\begin{array}{l}\text { Yes, uncertain if fish } \\
\text { are redistributed from } \\
\text { natural reefs or } \\
\text { produced on structure }\end{array}$ & ? \\
\hline $\begin{array}{l}\text { All marine } \\
\text { mammal } \\
\text { indicators, }\end{array}$ & $\begin{array}{l}\text { Operation of turbines } \\
\text { or other moving parts } \\
\text { of devices }\end{array}$ & $\begin{array}{l}\text { Moving device } \\
\text { parts }\end{array}$ & $\begin{array}{l}\text { Possible collision with } \\
\text { moving turbines }\end{array}$ & High & $\begin{array}{l}\text { Direct and } \\
\text { adverse }\end{array}$ & $\begin{array}{l}\text { Yes, uncertain if } \\
\text { collisions will occur }\end{array}$ & $?$ \\
\hline $\begin{array}{l}\text { All marine } \\
\text { mammal } \\
\text { indicators, rockfish } \\
\text { lingcod, and } \\
\text { cabezon }\end{array}$ & $\begin{array}{l}\text { Operation of turbines } \\
\text { or other moving parts } \\
\text { of devices }\end{array}$ & $\begin{array}{l}\text { Moving device } \\
\text { parts }\end{array}$ & $\begin{array}{l}\text { Noise that could change } \\
\text { animal's behavior }\end{array}$ & Unknown & $\begin{array}{l}\text { Indirect, } \\
\text { adverse and } \\
\text { beneficial }\end{array}$ & $\begin{array}{l}\text { Yes, noise from } \\
\text { devices and ambient } \\
\text { noise should be } \\
\text { measured }\end{array}$ & $?$ \\
\hline
\end{tabular}

Page 70 
revision

\begin{tabular}{|c|c|c|c|c|c|c|c|}
\hline $\begin{array}{l}\text { Sharks, juvenile } \\
\text { salmonids, diving } \\
\text { ducks, loons, } \\
\text { grebes, alcids, } \\
\text { cormorants }\end{array}$ & $\begin{array}{l}\text { Operation of turbines } \\
\text { or other moving parts } \\
\text { of devices }\end{array}$ & $\begin{array}{l}\text { Moving device } \\
\text { parts }\end{array}$ & $\begin{array}{l}\text { Possible collision with } \\
\text { moving turbines }\end{array}$ & Unknown, & $\begin{array}{l}\text { Direct and } \\
\text { adverse }\end{array}$ & $\begin{array}{l}\text { Yes, uncertain if } \\
\text { collisions will occur }\end{array}$ & $?$ \\
\hline $\begin{array}{l}\text { All marine } \\
\text { mammal } \\
\text { indicators, sharks, } \\
\text { skates, rays, } \\
\text { juvenile \& adult } \\
\text { salmonids }\end{array}$ & $\begin{array}{l}\text { Electricity conduction } \\
\text { through cable }\end{array}$ & EMF & $\begin{array}{l}\text { Possible changes in } \\
\text { orientation, behavior }\end{array}$ & Unknown & $\begin{array}{l}\text { Unknown if } \\
\text { effect occurs }\end{array}$ & $\begin{array}{l}\text { Yes, effects literature } \\
\text { is growing but no } \\
\text { consensus yet }\end{array}$ & $\begin{array}{l}\text { Shielding, "Faraday } \\
\text { cages", bury high- } \\
\text { voltage DC cables to } \\
\text { reduce EMF (EAO } \\
\text { British Columbia } \\
2009)\end{array}$ \\
\hline \multicolumn{8}{|c|}{ Decommissioning } \\
\hline Northern sea lion & $\begin{array}{l}\text { Boat traffic associated } \\
\text { with decommissioning }\end{array}$ & Direct impact & Collision injuries & Med & $\begin{array}{l}\text { Direct and } \\
\text { adverse }\end{array}$ & $\begin{array}{l}\text { No, effects } \\
\text { reasonably described }\end{array}$ & Vessel speed limits \\
\hline $\begin{array}{l}\text { Juvenile } \\
\text { salmonids }\end{array}$ & $\begin{array}{l}\text { Decommissioning of } \\
\text { structures on water's } \\
\text { surface or seabed }\end{array}$ & $\begin{array}{l}\text { Construction \& } \\
\text { deck lights }\end{array}$ & $\begin{array}{l}\text { Behavioral changes, more } \\
\text { vulnerable to predation }\end{array}$ & $\begin{array}{l}\text { Med, species } \\
\text { listed so take } \\
\text { prohibited }\end{array}$ & $\begin{array}{l}\text { Direct and } \\
\text { adverse }\end{array}$ & $\begin{array}{l}\text { No, effects } \\
\text { reasonably described }\end{array}$ & $\begin{array}{l}\text { Limit construction to } \\
\text { daylight hours }\end{array}$ \\
\hline
\end{tabular}




\subsection{Priority studies warranted for a pilot scale MCT SeaGen project at Tacoma Narrows}

Our final analysis was to identify potential effects that are sufficiently high and uncertain to warrant further study (Table 32); we compiled and summarized possible future studies from the overall risk evaluation table.

Table 32 - Possible future studies warranted for pilot scale MCT SeaGen project at the Tacoma site

\begin{tabular}{|c|c|c|}
\hline Indicator species or group & Potential Effect & Possible future studies \\
\hline $\begin{array}{l}\text { Diving ducks, loons, grebes, } \\
\text { cormorants, alcids, all marine mammal } \\
\text { indicators }\end{array}$ & $\begin{array}{l}\text { Attraction to increased prey (reef effect), } \\
\text { entanglement with lost fishing gear while } \\
\text { diving }\end{array}$ & $\begin{array}{l}\text { Use of structures could be } \\
\text { measured }\end{array}$ \\
\hline Flatfishes, juvenile and adult salmonids & $\begin{array}{l}\text { Reef effect, attraction of predators (e.g., } \\
\text { rockfish), changes in predator/prey } \\
\text { interactions }\end{array}$ & $\begin{array}{l}\text { Use of structures could be } \\
\text { measured }\end{array}$ \\
\hline $\begin{array}{l}\text { Diving ducks, loons, grebes, gulls, } \\
\text { cormorants, alcids }\end{array}$ & $\begin{array}{l}\text { Roosting habitat (gulls and cormorants only), } \\
\text { attraction to increased prey (FAD effect), } \\
\text { which could increase predation on other } \\
\text { species (i.e., salmon), collision while flying }\end{array}$ & $\begin{array}{l}\text { Flight paths, heights, use of } \\
\text { area, and collision rates } \\
\text { could be measured }\end{array}$ \\
\hline $\begin{array}{l}\text { Sharks, skates, rays, juvenile and adult } \\
\text { salmonids, all marine mammal } \\
\text { indicators }\end{array}$ & Changes in orientation, behavior due to EMF & $\begin{array}{l}\text { Effects literature is growing } \\
\text { but no consensus yet }\end{array}$ \\
\hline $\begin{array}{l}\text { All marine mammal indicators, diving } \\
\text { ducks, loons, grebes, cormorants, } \\
\text { alcids, sharks, juvenile salmonids }\end{array}$ & $\begin{array}{l}\text { Collision with moving turbines while diving or } \\
\text { foraging }\end{array}$ & $\begin{array}{l}\text { Use of area, structures, and } \\
\text { collision rates could be } \\
\text { measured }\end{array}$ \\
\hline $\begin{array}{l}\text { Rockfishes, lingcod, cabezon, green } \\
\text { sturgeon, humpback whales, killer } \\
\text { whales, small odontocetes }\end{array}$ & $\begin{array}{l}\text { Altered behavior, avoidance, masking of } \\
\text { environmental cues, communication signals } \\
\text { due to noise and vibration of devices }\end{array}$ & $\begin{array}{l}\text { Device noise should be } \\
\text { measured and compared to } \\
\text { noise effect thresholds in the } \\
\text { literature }\end{array}$ \\
\hline
\end{tabular}

\subsection{Application of a pilot scale MCT SeaGen project to other Tacoma scenarios}

The combination of 3 tidal energy technologies and 3 project scales results in 9 Tacoma scenarios. The detailed effects analysis was applied to installation, operations and maintenance, and decommissioning of a pilot scale SeaGen project. We can extrapolate the risks identified in this scenario to the other scenarios by considering the similarities and differences in technologies, and in project scale.

Boat traffic resulting in direct collision and injury was identified as a project activity that posed medium risk and exposure to some Northern sea lions in a pilot scale MCT SeaGen project at Tacoma Narrows. 
Risk and exposure due to boat traffic would be directly proportional to project scale; for all small and large commercial projects, we can assume that boat traffic effects will be greater than those identified in a pilot scale MCT SeaGen project at Tacoma Narrows.

For a pilot scale MCT SeaGen project at Tacoma Narrows, we determined that EMF effects remain unknown despite growing literature. EMF effects would also be project scale dependent, similar to boat traffic effects discussed above.

Artificial reef and FAD effects could change predator and prey relationships, attract sharks and predators to aggregated prey, and increase exposure to lost gear entanglement for marine mammals, fishes, and marine birds; these effects may vary technology. Entanglement risks may be greater for the SMD TidEl technology because it contains underwater moorings while the other technologies are rigidly anchored. A pilot scale MCT SeaGen project at Tacoma Narrows would have minimal FAD effects because there is little above-surface structures, and the other two technologies, SMD TidEl and Lunar Energy RTT, would have no FAD effects because there are no surface structures. Artificial reef effects, if there are any, would be expected to be greater for the SMD TidEl and Lunar Energy RTT devices because there is more structure on the seafloor; these effects would be expected to increase with a greater number of devices in the water. In addition, the Lunar Energy RTT technology has a greater number of devices at the large commercial scale than MCT SeaGen or SMD TidEl.

Structures on the water's surface could affect marine birds by providing roosting habitat (gulls and cormorants only), attract them to aggregated prey (which could increase predation on other species such as salmon), and pose collision risk while flying. A pilot scale MCT SeaGen project at Tacoma Narrows would have minimal FAD effects because there is little above-surface structures, and the other two technologies SMD TidEl and Lunar Energy Rotech would have no FAD effects, collision risks, or roosting habitat because there are no surface structures.

Construction lights and navigation lights on the devices in Scenario 25 were identified as posing a medium risk to alcids and juvenile salmonids. We assumed there would be no navigation lights on the SMD TidEl and Lunar Energy Rotech technologies because there are no surface structures; however, if navigational lighting is required then risks would need to be reconsidered. Construction lights for all scenarios would increase with a greater number of lights and/or an increased spatial footprint of the lights, which could occur with the larger-scale scenarios. 
Effects to the physical environment, including water quality, sediment transport, and tidal dynamics (energy, range) are scale-dependent; the larger (commercial) project scales are more likely to have effects on tidal dynamics that could influence the tidal habitats at distances far from the project. The extent that different tidal scenarios would have greater or lesser effect on tidal energy dynamics or on the physical environment has been estimated (Polagye 2009a); all tidal scenarios would have minimal effects $(<1 \%$ even for commercial-scale array) on volume of water exchanged in south Puget Sound.

Marine mammals, diving marine birds, sharks, and juvenile salmonids could collide with underwater turbines while diving or foraging; these effects would be expected to be similar for all devices because the underwater turbines are similar in size and scale. However, these effects would be expected to increase with a greater number of devices in the water. The Lunar Energy RTT technology has the greatest number of devices per energy output at all three scales than the SMD TidEl and MCT SeaGen.

The noise characteristics produced by the devices are unknown, but likely varies among all of the technologies. Amplitude and frequency of noise emitted by devices could vary significantly by technology and scale; a device's amplitude determines the noise propagation, or how far the sound travels, and its frequency determines the marine mammal species that can detect or are affected by the noise. At this time, we have no basis for assessing the noise characteristics among technologies, or for comparing the effects of the noise produced by different types of devices or at different scales on marine mammals. 


\section{Raptools}

The second methodology, Raptools, is a collaborative approach useful for evaluating multiple characteristics of numerous siting or technology alternatives, and it allows us to graphically compare alternatives. We used Raptools to answer these questions:

- How do the scenarios compare, in terms of exposure, risks, and effects to the ecological and human environments?

- Are there sites that seem to present the fewest effects regardless of technology and scale?

- Which attributes account for many or much of the effects associated with wave or tidal energy development?

Other questions, such as what are the cumulative effects of many marine renewable projects, or how global climate change add to potential effects of marine renewable projects, could also be answered using Raptools.

We characterize our application of the Raptools method as a trial run, as it is early in its development. In the future, with further development, it should be useful to inform many of the important questions concerning wave and tidal energy development, as well as other developments in hydrokinetics. In our trial run of Raptools, we used input data that have not been peer-reviewed and vetted by others in the energy development field; we used "trial run" data to illustrate the utility of the Raptools method. We compared how the wave and tidal energy technologies, project scales, and sites compare with each other; and we compared project technologies and scales at a given site. This trial run serves as an illustrative guide to the Raptools methodology in its early stage of development.

Although in its early phase of development, in the future the Raptools method will be useful to decisionmakers, stakeholders, resource managers, and developers to evaluate potential ocean energy projects and their siting. Our presentation of Raptools should be considered a work-in-progress, but it is sufficiently developed such that we can determine its value and we describe steps to refine and improve its utility. We anticipate that improvements will be made to this methodology (and we suggest improvements in Section 7). Further improvements and suggestions will come from reviewers representing the abovementioned groups.

Raptools allows us to objectively and quantitatively evaluate and compare multiple attributes of numerous scenarios, such as for screening sites. Due to the complex and multidisciplinary nature of these assessments, an objective and repeatable method for comparing such projects, especially in the absence of 
quantitative information, is broadly recognized as needed. In this trial run of Raptools, we identify, define, and score critical attributes of project alternatives, and create graphics that clearly illustrate how alternatives or scenarios compare with 1) "best" and "worst" case scenarios, and 2) other competing scenarios. The Raptools method is based on statistically intricate underpinnings, but relies on wellestablished and thoroughly vetted procedures; technical and statistical details are confined to Appendix B.

Raptools borrows its statistical and analytical structure from Rapfish (Pitcher 1999, Pitcher and Preikshot 2001), a method developed to compare the relative sustainability of commercial fisheries; in Raptools, the application has changed, which requires that the attributes and scoring structure also change. As the names imply, the methods are rapid assessment tools for evaluating complex alternatives when quantitative information is limited. This approach offers a suitable means for objectively assessing diverse attributes (T. Pitcher, personal communication, 2 February 2009).

Raptools provides:

- a graphical comparison of project scenarios based on a scoring structure,

- leveraging analyses that allow us to compare the importance of each attribute with other attributes, and

- kite diagrams that illustrate the strengths and weaknesses of scenarios relative to a "perfect" scenario and relative to each other.

To run Raptools, a user needs to select attributes that can be evaluated for each scenario. Further, the attributes need to be characteristics that can be scored relative to best and worst-case scenarios. We selected and defined attributes for wave and tidal energy development scenarios for this trial run, and grouped them into 4 categories:

1. siting

2. project/technology

3. ecology

4. human environment

We used literature review and professional judgment to select generic attributes that are important considerations when siting wave and tidal energy developments, and to define and assign score ranges. Attribute selection and scoring could also be done by polling stakeholders, with a goal of gaining consensus on the important attributes and the ranges of possible scores. Score ranges can vary based on how well we can define the potential effect. In this trial run, we varied attribute scores from 0 to 1 , to 0 to 4 (Table 33); a wider range was assigned when the attribute was relatively well understood and when 
attribute effects could be recognized into more discrete categories. For an attribute that is not well defined, a score range of only 0 to 1 was assigned because the potential effect is less certain and quantifiable; however, we can predict that it is more likely (1) or less likely (0) based on the environmental characteristics of the site. Siting attributes and scoring used in the trial run of Raptools are further described in Appendix C.

Raptools uses a well-established statistical method called multi-dimensional scaling, which is a nonparametric method that focuses the statistical analysis on the rankings of items (in this case, the scores), not on the numerical value of the score itself. The focus on rankings or order means that: 1) a wider range of scores does not generate more "weight" in the analysis and 2) the "direction" of score ranges does not affect the analysis.

After attributes and score ranges are selected, scores are assigned for each attribute of a specific scenario or project. The result is a matrix of scenarios (rows) and attributes (columns) with a score in each cell. The relative similarity among scenarios, including best- and worst-case scenarios, can be determined and represented graphically as a constellation of points on two or three axes (the graphical output of an “ordination", here using multidimensional scaling (Pitcher and Preikshot 2001). In this way, scenarios having multiple attributes with varying scores can be evaluated and compared. For a more detailed description of the Raptools model see Appendix B.

The primary utility of Raptools is its ability to compare multiple scenarios using a standard and objective approach, and to identify critical attributes when many variables are at play. It can also be used to measure the uncertainty or lack of accord when scoring scenario attributes. Raptools compares favorably to other less inclusive (and often less quantitative) methods for evaluating complex systems (see Leadbitter and Ward 2007). This method is also significantly easier to implement than the effects analysis previously described.

The results of the Raptools ordinations can be visualized graphically, allowing an evaluation of the relationships between many attributes. However, the graphics are not intuitively easy to interpret and they require an initial short introduction before becoming easily understood. We have selected three types of Raptools ordination graphics in this trial run; they are presented in the Raptools results section (Section 6.1.2). 
We performed a trial run of the Raptools methodology using attributes and scores that we assigned, based on professional judgment and literature review (the results are found in Appendix C). Based on our trial run, we report on the usability and capabilities of Raptools in this section. In summary, in the future with further refinement, Raptools could be a very useful approach for screening sites by comparing numerous scenarios under varying project scales and device technologies.

\subsection{Attribute and score range selection}

The generic attributes were selected and scored; a spreadsheet containing the scores and the multidimensional scaling statistical calculations were applied (Appendix C). The attributes and scorings used in this trial run are supported by the literature and professional judgment. However, even among ourselves, we found selecting the attributes and assigning the scores to be a difficult task. Our main difficulties manifested in 1) finding attributes that are directly measurable but that also directly represent an exposure, a probability of happening, and therefore, an effect, and 2) realizing that our choice of attributes limited the types of questions that Raptools results could answer.

An example of an attribute that was directly measurable but only indirectly presenting an effect is the "distance to shore" attribute. It is a "good" attribute in that it is measurable and objective. However, how well it represented an effect was difficult to assess. If a wave energy device is far from shore, effects nearshore should be less because the "wave shadow" effect will be less, and because device lights will be less noticeable. Conversely, if a device is far from shore, then vessel traffic to construct and maintain it will increase, and risks associated with vessel traffic (animal-boat collisions, fuel and oil releases) would increase. Of the 32 attributes selected in this Raptools trial run, approximately 5 or 6 indirectly present exposure and/or probability of occurrence. Indirect relationships are ecologically important to recognize, but they can become limiting when their scoring becomes less clear.

In applying the Raptools methodology, our intent was to use the wave and tidal energy device scenarios at the three sites to "test" the methodology; hence, we attempted to select attributes that would be applicable to both wave and tidal devices and sites. However, those attributes may not be appropriate for screening specific wave or tidal sites; some of the attributes became less informative. An example of this would be the "beach slope" attribute. It is an attribute that represents the width of the intertidal zone; the steeper the slope, the narrower the intertidal zone, and the less exposure of that ecologically important area. This attribute separates the Humboldt and Makapu'u sites well, but are less useful for tidal sites. However, 
selection of the attributes is part of the usefulness of Raptools in that there is flexibility to develop attributes to address specific questions.

Our selection of attributes and scores was sufficient for this trial run of Raptools. To improve the selection, a preferred approach would be to utilize input from diverse stakeholder groups. This approach would permit an analysis of those points on which there is concordance as well as disagreement and uncertainty, suggesting priorities for collaborative work and education.

\subsection{Example Raptools output}

In this Raptools trial run, we selected attributes and scores and generated some example Raptools graphics. These graphics are representative of those that could answer the questions that are important in an over-arching, national-level discussion on wave and tidal energy development (Figure 7).

Table 33 - Questions addressed in this trial Raptools application

\begin{tabular}{|l|l|}
\hline \multicolumn{1}{|c|}{ Question } & $\begin{array}{c}\text { Raptools graphic allowing } \\
\text { analysis of question }\end{array}$ \\
\hline $\begin{array}{l}\text { 1. Given 4 wave energy and 3 tidal technologies, 3 project scales, and 3 potential } \\
\text { sites, how do the scenarios compare, in terms of exposure, risks, and effects to the } \\
\text { ecological and human environments? }\end{array}$ & X-Y ordination graphs \\
\hline $\begin{array}{l}\text { 2. Are there sites that seem to present the fewest effects regardless of technology } \\
\text { and scale? }\end{array}$ & $\begin{array}{l}\text { Kite diagram, } \\
\text { geographic location }\end{array}$ \\
\hline $\begin{array}{l}\text { 3. Which attributes account for many or much of the effects associated with wave } \\
\text { or tidal energy development? }\end{array}$ & Leveraging bar graphs \\
\hline
\end{tabular}

On an X-Y ordination graph, scenarios presenting the fewest effects are plotted as points towards the right, and scenarios presenting the most effects are plotted as points on the left side of the graph. In the $\mathrm{X}-\mathrm{Y}$ ordination graph of the trial run siting attributes, all 33 scenarios have been evaluated and plotted, but many points over-lay each other, so fewer than 33 points are readily apparent (Figure 7). For example, Point 1 on the siting ordination graph (Figure 7) actually represents 9 scenarios, which are all 3 scales of the Pelamis P-2, Power Buoy, and Wave Dragon technologies at Makapu'u. Point 7 also represents 9 scenarios, which are all 3 scales of all 3 tidal technologies at the Tacoma Narrows site. 


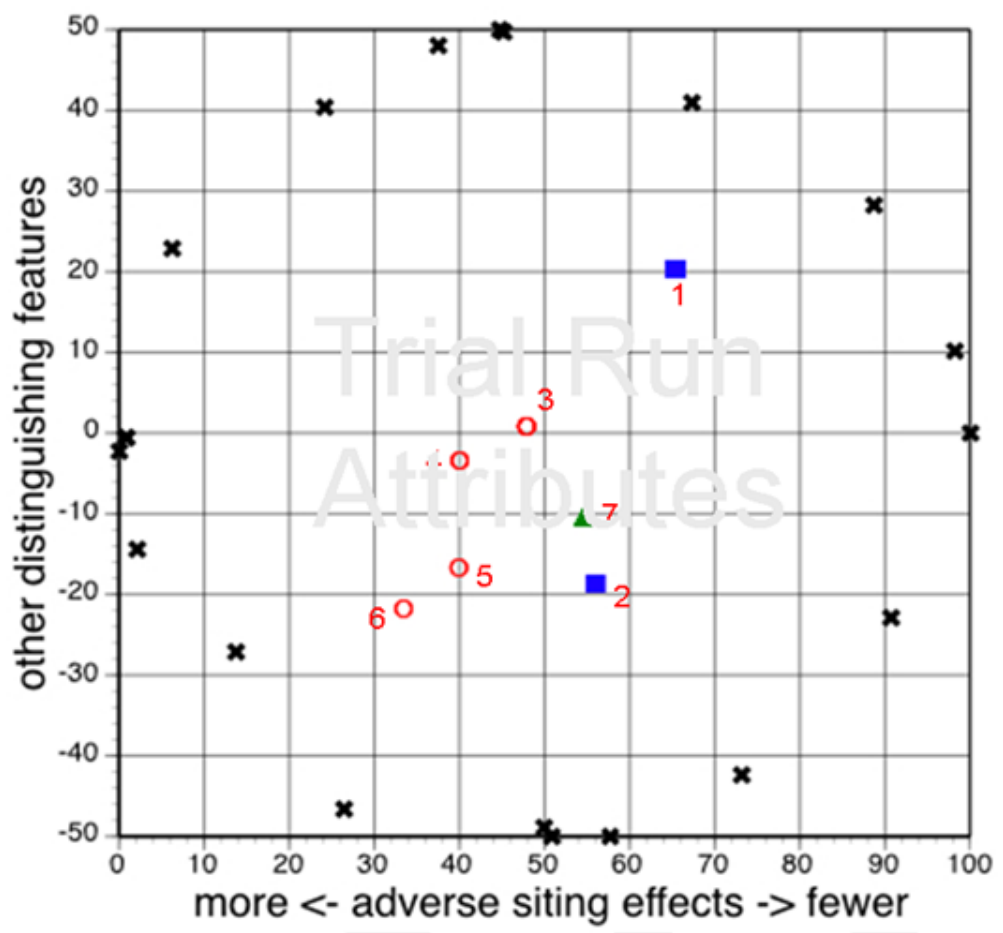

- Makapu'u

- Humboldt

- Tacoma

× Anchor points

1 Pelamis P-2, Power Buoy, Wave Dragon, all scales

2 Oyster all scales

3 Pelamis P-2, Power Buoy, Wave Dragon, pilot and small commercial

4 Pelamis P-2, Wave Dragon, large commercial

5 Oyster, pilot and small commercial

6 Oyster, large commercial

7 SeaGen, RTT, TidEI, all scales

Figure 7 - Raptools X-Y ordination graph resulting from trial run of siting attributes.

Based on the trial run siting attributes, the Makapu'u and Tacoma sites present fewer adverse effects than does the Humboldt site (Figure 8). A number of attributes contributed to this result, for example the beach slope at Makapu'u is much steeper than at Humboldt; the steeper the beach slope, the narrower the biologically diverse intertidal zone, which would be subjected to fewer effects by a project.

The Raptools attributes and ordination graph can also distinguish the least adverse and greatest beneficial scenarios; in the trial run of the human environment attributes, the large commercial scale projects present the fewest adverse (and most beneficial) effects because they contribute the most to the attribute of contributing to renewable energy.

The kites diagrams generated through Raptools allow us to visually compare sites. In this example, the site that presents the fewest adverse effects regardless of technology and scale is Makapu'u, based on the trial siting, technology, and ecological attributes (Figure 8). 


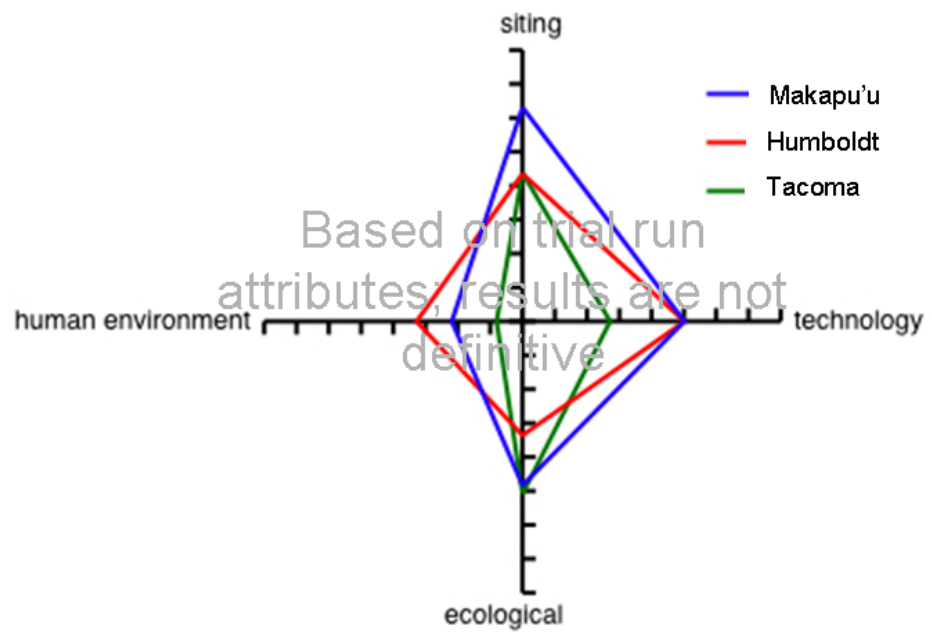

Figure 8 - The Makapu'u site generally presents the fewest adverse effects, based on trial run siting, technology, and ecological attributes.

The Raptools leveraging bar graphs indicate the relative importance of the attributes in the evaluations of adverse effects (Figure 8). The attribute exhibiting the longest bar is the most influential attribute, in the context of the attributes category or set. Conversely, the shortest bar represents an attribute that does affect the others as much. As stated previously, we selected these attributes based on professional judgment and literature review; they should be considered preliminary and for illustrative purposes only.

If we couple our knowledge of uncertainty with these leveraging analyses, we can begin to identify which attributes might be a priority for further studies. For example, from an ecological perspective, the "de facto marine reserve" attribute is not as important as the others (Figure 9-C). Therefore, although we do not know the degree to which a wave energy project will become a de-facto marine reserve, neither is this uncertainty a priority in terms of limited research funding. On the other hand, artificial reef effects have strong effects on this evaluation, and greater knowledge of how these effects may vary depending on marine hydrokinetic project characteristics are likely to be disproportionately valuable. 


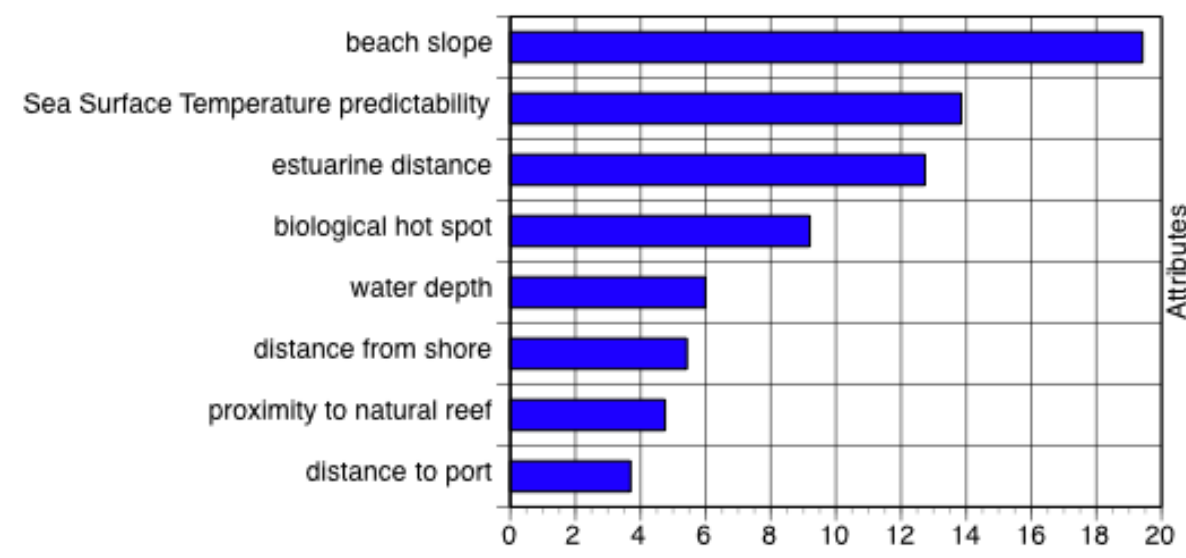

A. Siting attributes

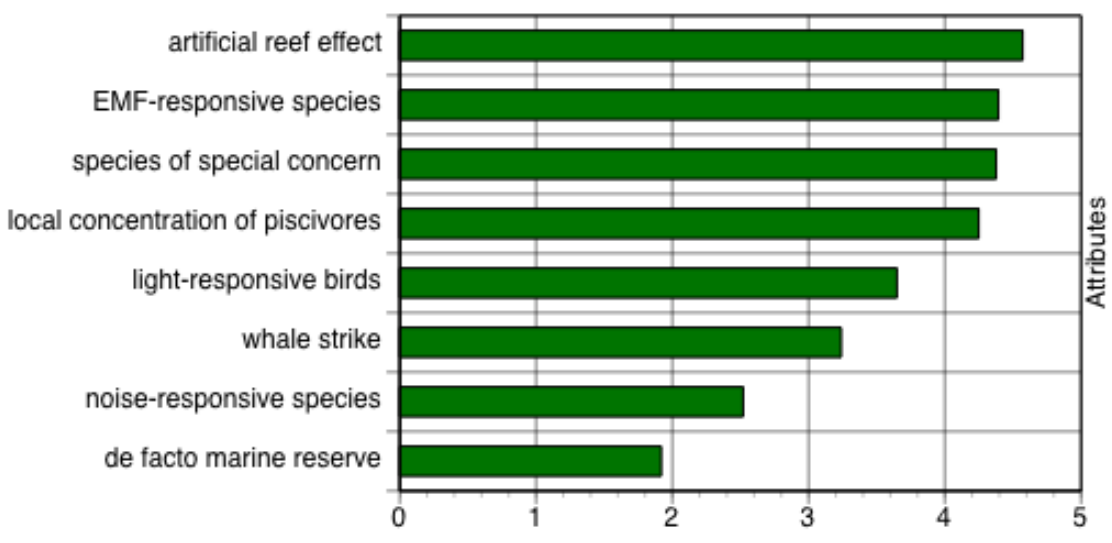

C. Ecological attributes

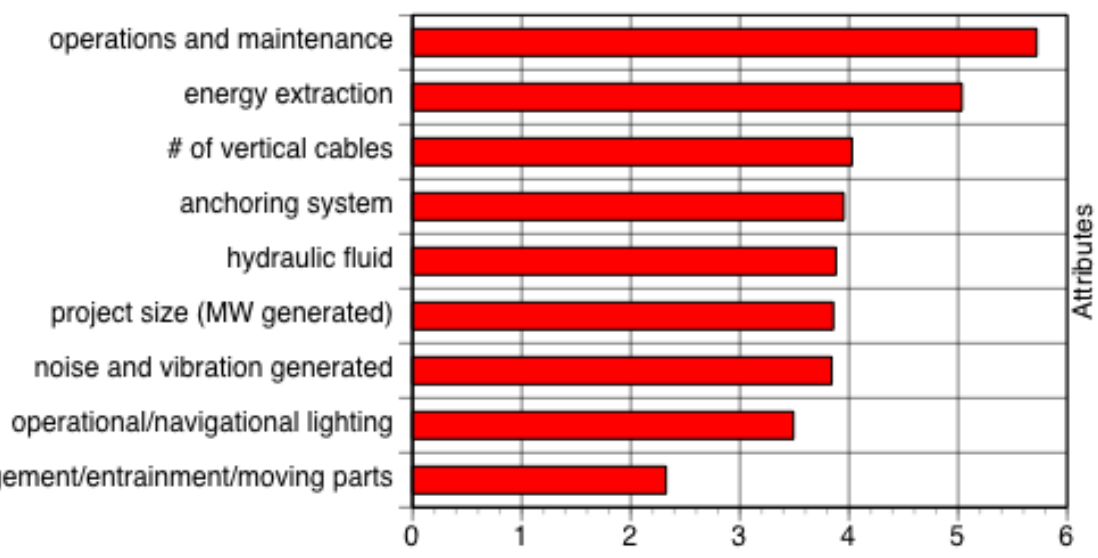

B. Technology attributes

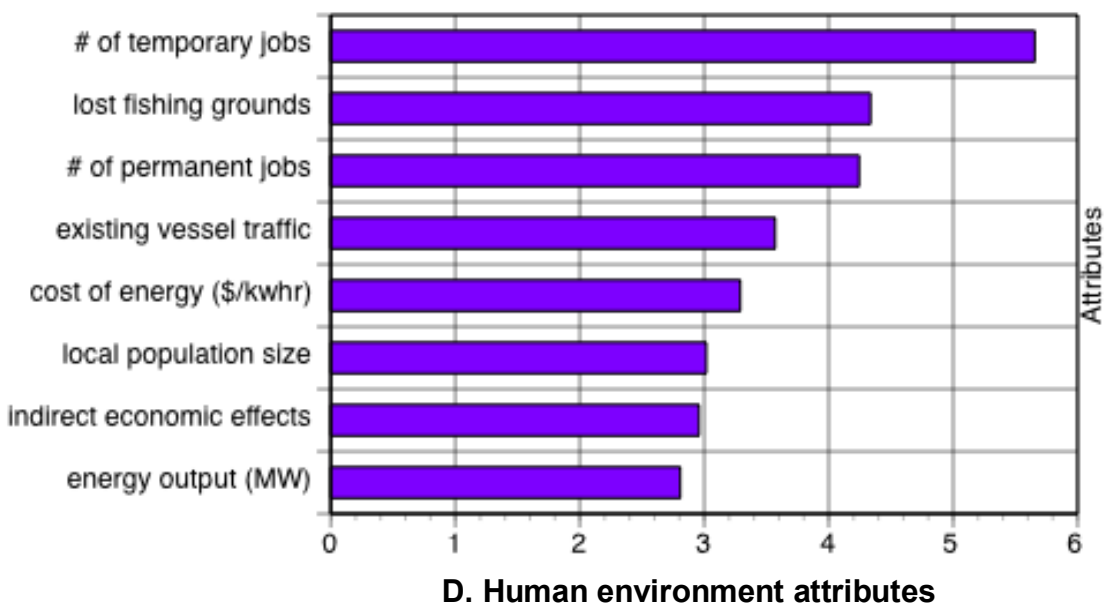

D. Human environment attributes

Figure 9 - Raptools leveraging bar graphs. The attribute exhibiting the longest bar is the most influential attribute in the set. Successive and individual removals of attributes, while observing effects on the other attributes, is termed "leverage analysis." These attributes should be considered illustrative and useful for testing the Raptools method. 


\subsection{Raptools summary}

Important questions can be addressed through the Raptools analysis, as illustrated by the example Raptools graphics. The selections of attributes and scores define the types of questions that can be addressed; the trial run attributes and scores need to be reviewed and discussed among all stakeholders, including technology developers, governmental agencies, and the interested public. Once the attributes and scores have been vetted, re-running Raptools would allow us to more definitively answer regional and site-specific questions.

This methodology is able to explore degrees of certainty. In the trial run of Raptools, uncertainty is inherent in the choice of scoring ranges, in which a narrow range implies greater uncertainty. An explicit treatment of uncertainty could be evaluated by further developing and re-running the Raptools analysis by systematically varying those attributes that are highly influential (that is, by running a sensitivity analysis). For example, the artificial reef effect is a highly influential attribute in the ecological attributes set. By varying the artificial reef score, we can determine how and if the ordinations (and their graphics) would change.

While particularly useful in marine spatial planning, and site and technology-screening, a Raptools analysis would likely not be sufficiently detailed for permitting; an environmental effects analysis approach is more suitable for permitting. 


\section{Conclusions}

In this report, we crafted and tested two methodologies, one for broad comparisons of the potential effects of many alternative scenarios (Raptools), and the other for identifying the potential environmental effects of wave and tidal energy technology devices at a given site. Using the Raptools method, we considered 33 scenarios, which were generated by combinations of 4 wave technologies, 3 tidal technologies, 3 sites, and 3 project scales. We then identified the potential environmental effects of 3 scenarios using a risk assessment-based framework that used tables to systematically and transparently identify key environmental concerns.

\subsection{Key environmental concerns and "next steps"}

Our detailed analyses of the three scenarios (small commercial scale OPT Power Buoy at Humboldt, California, small commercial scale Pelamis P-2 at Makapu'u, Hawaii, and the pilot scale MCT Sea Gen at Tacoma Narrows, Washington), indicate that several key environmental concerns are common to all three scenarios. (We define "key" as those environmental effects that posed unmitigated medium or high risks, or that had so little data available that effects could not be evaluated.) The key concerns provide the basis to define the next steps for continuing developing marine renewable energy (Table 34); the steps include evaluating key concerns through studies generally applicable to all marine hydrokinetic developments, or studies needed on a pilot scale and site-specific basis. In some circumstances generic study information may still need to be combined with pilot project studies at a specific site. For example, we may learn that marine mammals are generally able to sense devices and avoid them, but that ability is likely site and device-specific.

Table 34. Key environmental concerns and next steps

\begin{tabular}{|c|c|c|c|}
\hline $\begin{array}{l}\text { Key environmental } \\
\text { concerns }\end{array}$ & $\begin{array}{l}\text { Next steps for continuing marine } \\
\text { hydrokinetic energy development }\end{array}$ & $\begin{array}{l}\text { Study results } \\
\text { generally } \\
\text { applicable to } \\
\text { all marine } \\
\text { hydrokinetic } \\
\text { developments }\end{array}$ & $\begin{array}{l}\text { Study results } \\
\text { needed on a } \\
\text { pilot project } \\
\text { and site } \\
\text { specific basis }\end{array}$ \\
\hline \multirow{4}{*}{$\begin{array}{l}\text { Noise and vibration in the } \\
\text { acoustic environment from } \\
\text { boat traffic, project } \\
\text { construction and } \\
\text { decommissioning, and the } \\
\text { energy devices }\end{array}$} & $\begin{array}{l}\text { Noise from energy devices needs to be } \\
\text { measured; noise will be device-specific. }\end{array}$ & $\mathrm{X}$ & \\
\hline & Ambient noise conditions need to be measured. & & $\mathrm{X}$ \\
\hline & $\begin{array}{l}\text { Species thresholds and behavioral changes } \\
\text { need to be established if not already } \\
\text { documented in the literature. }\end{array}$ & $\mathrm{X}$ & \\
\hline & $\begin{array}{l}\text { Noise from boat traffic and construction and } \\
\text { decommissioning needs to be established if not } \\
\text { already documented in the literature. }\end{array}$ & $\mathrm{X}$ & \\
\hline $\begin{array}{l}\text { Collision effects from boat } \\
\text { traffic for pinnipeds, } \\
\text { cetaceans, sea turtles, and } \\
\text { marine birds }\end{array}$ & $\begin{array}{l}\text { Existing navigation safety and best } \\
\text { management practices to avoid and minimize } \\
\text { species and vessel collisions should be applied } \\
\text { to marine energy development. }\end{array}$ & $\mathrm{X}$ & \\
\hline
\end{tabular}




\begin{tabular}{|c|c|c|c|}
\hline $\begin{array}{l}\text { Key environmental } \\
\text { concerns }\end{array}$ & $\begin{array}{l}\text { Next steps for continuing marine } \\
\text { hydrokinetic energy development }\end{array}$ & $\begin{array}{l}\text { Study results } \\
\text { generally } \\
\text { applicable to } \\
\text { all marine } \\
\text { hydrokinetic } \\
\text { developments }\end{array}$ & $\begin{array}{c}\text { Study results } \\
\text { needed on a } \\
\text { pilot project } \\
\text { and site } \\
\text { specific basis }\end{array}$ \\
\hline $\begin{array}{l}\text { Seabed disturbance during } \\
\text { construction, directional } \\
\text { drilling, and } \\
\text { decommissioning, resulting } \\
\text { in temporary loss of } \\
\text { benthic invertebrates or } \\
\text { algae (food resources and } \\
\text { habitat) for sea turtles and } \\
\text { marine birds }\end{array}$ & $\begin{array}{l}\text { Studies to determine the degree and duration of } \\
\text { the habitat loss need to be designed, if the } \\
\text { short-term nature of construction does not } \\
\text { constitute a less than significant effect. Best } \\
\text { management practices to avoid and minimize } \\
\text { effects to seabed disturbance should be applied } \\
\text { to marine energy development }\end{array}$ & $X$ & \\
\hline $\begin{array}{l}\text { Lights used in construction } \\
\text { and decommissioning } \\
\text { causing disorientation, } \\
\text { collisions of some marine } \\
\text { birds, fishes, and pinnipeds }\end{array}$ & $\begin{array}{l}\text { Studies to determine the degree and extent of } \\
\text { these behaviors could be designed, if } \\
\text { construction using similar strength lights cannot } \\
\text { indicate the probability of attraction, } \\
\text { disorientation, or collisions occurring, and if the } \\
\text { short-term nature of construction does not } \\
\text { constitute a less than significant effect. }\end{array}$ & $x$ & \\
\hline $\begin{array}{l}\text { Navigation lights causing } \\
\text { collisions and/or increased } \\
\text { vulnerability to predation } \\
\text { for some marine birds, } \\
\text { fishes, and pinnipeds }\end{array}$ & $\begin{array}{l}\text { Observation studies to determine the degree } \\
\text { and extent of these behaviors could be } \\
\text { designed, if species reactions to navigation } \\
\text { lights are documented to occur. If attraction and } \\
\text { predation is observed, mitigations for navigation } \\
\text { lights could be required. }\end{array}$ & $X$ & \\
\hline $\begin{array}{l}\text { Collision with underwater } \\
\text { moving turbines, devices, } \\
\text { and mooring lines for } \\
\text { marine mammals and } \\
\text { marine birds }\end{array}$ & $\begin{array}{l}\text { Observation studies using remotely operated } \\
\text { vehicles, divers or acoustic cameras need to be } \\
\text { performed on pilot projects but results likely to } \\
\text { be broadly applicable. If collisions are } \\
\text { documented, mitigation measures such as re- } \\
\text { designing the technologies and mooring } \\
\text { systems should be designed, and tested again. }\end{array}$ & $x$ & $x$ \\
\hline $\begin{array}{l}\text { Entanglement with } \\
\text { underwater mooring lines } \\
\text { or lost fishing gear for } \\
\text { marine mammals, marine } \\
\text { birds, and sea turtles }\end{array}$ & $\begin{array}{l}\text { Observation studies using remotely operated } \\
\text { vehicles, divers or acoustic cameras need to be } \\
\text { performed on pilot projects but results likely to } \\
\text { be broadly applicable. If entanglement is } \\
\text { documented, mitigation measures such as re- } \\
\text { designing the technologies and mooring } \\
\text { systems, or increasing monitoring and } \\
\text { maintenance of device and lines should be } \\
\text { designed, and tested again. }\end{array}$ & $x$ & $x$ \\
\hline \multirow{2}{*}{$\begin{array}{l}\text { Effects of EMF from } \\
\text { transmission cables and } \\
\text { from devices on some fish } \\
\text { species and marine } \\
\text { mammals }\end{array}$} & $\begin{array}{l}\text { EMF from energy devices and transmission } \\
\text { cables needs to be measured; EMF will be } \\
\text { device-specific. }\end{array}$ & $x$ & \\
\hline & $\begin{array}{l}\text { Species thresholds and behavioral changes } \\
\text { need to be established if not already } \\
\text { documented in the literature. }\end{array}$ & $x$ & \\
\hline $\begin{array}{l}\text { FAD and artificial reef } \\
\text { effects on fishes, marine } \\
\text { mammals, and marine } \\
\text { birds }\end{array}$ & $\begin{array}{l}\text { Tagged fish studies and visual observation of } \\
\text { marine mammals and seabirds studies need to } \\
\text { be performed on pilot projects. If species are } \\
\text { present in greater numbers after the project and } \\
\text { if species of concern are indicated as prey, then } \\
\text { mitigation measures should be designed. }\end{array}$ & $x$ & $x$ \\
\hline
\end{tabular}

Studies that address noise, seabed disturbance, underwater collision, entanglement, and EMF are likely to inform marine renewable energy projects at many locations and using various technologies. For example, 
EMF at the cables and devices can be measured so that we understand the types and strengths of the fields. Similarly, noise from the devices can be measured, but the actual exposure will depend on individual species' use of the project area, and the ambient noise existing prior to project installation. In addition, the effects of the noise will depend on species' auditory sensitivities. Studies that address key environmental concerns that could be generally applicable to marine renewable projects could be addressed at the national level; these efforts should determine appropriate thresholds for significance as well as mitigations to reduce effects so that they are less than significant.

Attraction of fish species to devices or their moorings (FAD or artificial reef effects) is a behavior inherent to a species and therefore is likely to occur wherever the species lives, thus information learned about a fish's behavior at a project will be broadly applicable to other projects within the region where the species occurs. FAD and artificial reef effects are not well understood, especially in temperate coastal waters, and some effects are likely be site specific. For example, it is not known whether devices could enhance production or merely attract animals from elsewhere: these effects will depend on the proximity to natural reefs and other site specific characteristics.

\subsection{Minimization Measures, Monitoring and Adaptive Management}

This framework identified ways to minimize and avoid potential effects, through the potential mitigation columns in the overall risk tables (Table 13 and Table 14 for Humboldt, Table 22 and Table 23 for Makapu'u, and Table 30 and Table 30 for Tacoma Narrows). In the environmental effects analysis, potential mitigation measures are tabulated in the overall risk tables. Some measures are site-specific (for example, limiting drilling so it occurs outside of the marbled murrelet nesting season at Humboldt), but others are generally true across sites. These generally applicable minimization and mitigation measures include:

- limiting vessel speed limits to prevent collisions with marine mammals,

- limiting construction and decommissioning activities to daylight hours to prevent use of bright lights,

- periodically removing entangled lost fishing gear to reduce entanglement risks to marine mammals, and

- designing structures that prevent pinniped haul-out

For potential effects that require additional study to either design mitigations or to determine mitigation effectiveness, a stepwise adaptive management approach is recommended. Adaptive management generally consists of identifying the project action or activity that may result in a negative effect on a species, and defining stepwise objectives and studies that eliminate explanatory causes of the effect. For 
example, if the concern is entanglement of marine mammals with devices or cables or lost fishing gear, the first monitoring efforts would determine if marine mammals are present in the project area. If they are not present, then entanglement risk is very low. But if monitoring results indicate that marine mammals are present, then the next study would determine if lost fishing gear becomes entangled in device mooring lines. If lost fishing gear does become entangled in mooring lines, the risk to marine mammals increases, because both marine mammals and entangled fishing gear are present. The last study would be designed to determine if marine mammals that are present become entangled in the lost fishing gear and device moorings. At any point in the adaptive management process, mitigations can also be tested; in the case of entanglement, more frequent monitoring and routine removal of lost fishing gear could decrease entanglement to a point where marine mammals do not come into contact with lost gear although both marine mammals and cables are in the project area. As discussed above, studies that are broadly applicable to marine hydrokinetic projects should be evaluated at the national level; however, since lost fishing gear and marine mammal species' use of specific areas differs by location, and project mooring lines design and size will vary, some project-specific monitoring will likely be necessary and the adaptive management approach will allow developers the ability to address uncertainty in a step-wise, focused manner.

\subsection{Findings}

Our findings indicate that many of the key environmental concerns associated with marine hydrokinetic development can be addressed through studies that may be broadly applicable to projects, e.g., although there are environmental concerns and high uncertainty associated with potential effects, not every project will likely need to evaluate every potential concern. An effort at the national level to address these environmental concerns through studies should provide information that is generally applicable to marine renewable projects; these efforts should determine appropriate thresholds for significance as well as mitigations to reduce effects so that they are less than significant. For example, it would be valuable to evaluate potential effects associated with EMF at the national level, including developing thresholds for EMF and species sensitivities, rather than address potential effects on a project by project basis.

Several key potential environmental effects may be addressed through best management practices or mitigations, and the use of adaptive management. Marine renewable project developers should consider a focused adaptive management approach to addressing key environmental concerns that cannot be addressed generically, or where there is a high degree of uncertainty. Lastly, the identified key environmental effects will likely be minor, and it is likely that all of them can be mitigated to a less than 
significant impact. Therefore it is of critical importance that demonstration marine renewable energy projects proceed so that evaluations can be conducted and remaining uncertainties addressed. 


\section{References}

AECOS Inc. 2002. Inventory catalogue of Hawaii's coral reefs. Hawaii Wildlife Fund.

Aponte NE, Ballantine DL. 2001. Depth distribution of algal species on the deep insular fore reef at Lee Stocking Island, Bahamas. Deep Sea Research Part I: Oceanographic Research Papers 48:2185-2194.

Black A. 2005. Light induced seabird mortality on vessels operating in the Southern Ocean: incidents and mitigation measures. Antarctic Science. 17(1):67-68.

Boehlert GW, McMurray GR, Tortorici CE. 2008. Ecological effects of wave energy development in the Pacific Northwest. National Oceanic and Atmospheric Administration. NMFS-F/SPO-92.

Bohnsack JA, Johnson DL, Ambrose RF. 1991. Ecology of artificial reef habitats and fishes. In: Seaman Jr. WJ, Sprague LM, editors. Artificial habitats for marine and freshwater fisheries. New York: Academic Press; p. 61-108.

Brodeur RD, Daly EA, Schabetsberger RA, Mier KL. 2007. Interannual and interdecadal variability in juvenile coho salmon (Oncorhynchus kisutch) diets in relation to environmental changes in the northern California Current. Fisheries Oceanography. 16(5):395-408.

Bruderer B, Peter D, Steuri T. 1999. Behaviour of migrating birds exposed to X-band radar and a bright light beam. Journal of Experimental Biology. 202(9):1015-1022.

Cada GF. 2008. The potential environmental impacts of marine and hydrokinetic renewable energy technologies. Washington, DC: Wind and Hydropower Technologies Program, U.S. Department of Energy. ER08-1040.

Cada GF, Ahlgrimm J, Michael B, Bigford T, Stavrakas SD, Hall D, Russell M, Sale M. 2007. Potential impacts of hydrokinetic and wave energy conversion technologies on aquatic environments. Fisheries. 32(4):174-181.

Clokie JJP, Scoffin TP, Boney AD. 1981. Depth maxima of Conchocelis and Phymatolithon rugulosum on the N. W. Shelf and Rockall Plateau. Marine Ecology Progress Series 4:131-133.

Dewees CM, Sortais K, Krachey MJ, Hackett SC, Hankin DG. 2004. Racing for crabs...costs and management options evaluated in Dungeness crab fishery. California Agriculture. 58(4):186-193.

Duggins DO, Eckman JE, Siddon CE, Klinger T. 2003. Population, morphometric and biomechanical studies of three understory kelps along a hydrodynamic gradient. Marine Ecology Progress Series 265:57-76.

EAO British Columbia. 2009. NaiKun Offshore Wind Energy Project, Under review application and supporting studies [Internet]. [updated 2 September 2009; cited 2 September 2009]. Available from: http://a100.gov.bc.ca/appsdata/epic/html/deploy/epic project doc list $230 \mathrm{r}$ app.html.

(EMEC) European Marine Energy Centre. 2005. Environmental Impact Assessment (EIA) guidance for developers at the European Marine Energy Centre. Orkney, Scotland. 
Eckman JE, Duggins DO, Siddon CE. 2003. Current and wave dynamics in the shallow subtidal: implications to the ecology of understory and surface-canopy kelps. Marine Ecology Progress Series 265:45-56.

Evans III EC, Norris KS. 1988. On the evolution of acoustic communication systems in vertebrates, Part II: Cognitive aspects. In: Nachtigall PE, Moore PWB, editors. Animal Sonar. Plenum Publishing Corporation; p. 671-681.

Faber Maunsell and Metoc PLC. 2007. Scottish Marine Renewables - Strategic Environmental Assessment (SEA) - Environmental report. The Scottish Executive.

(GESAMP) IMO/FAO/UNESCO-IOC/UNIDO/WMO/IAEA/UN/UNEP Joint Group of Experts on Scientific Aspects of Marine Environmental Protection. 2008. Assessment and communication of environmental risks in coastal aquaculture. Rome, Italy: Food and Agriculture Organization of the United Nations (FAO). Reports and Studies GESAMP No. 76.

Gill AB. 2005. Offshore renewable energy: ecological implications of generating electricity in the coastal zone. Journal of Applied Ecology. 42:605-615.

Graham MH, Kinlan BP, Druehl LD, Garske LE, Banks S. 2007. Deep-water kelp refugia as potential hotspots of tropical marine diversity and productivity. Proceedings of the National Academy of Sciences of the United States of America 104:16576-16580.

Grigg RW. 2006. Depth limit for reef building corals in the Au'au Channel, S.E. Hawaii. Coral Reefs. 25:77-84.

Gunderson DR, Armstrong DA, Shi Y-B, McConnaughey RA. 1990. Patterns of estuarine use by juvenile English sole (Parophrys vetulus) and Dungeness crab (Cancer magister). Estuaries. 13(1):59-71.

Hankin DG, Warner RR. 2001. Dungeness Crab. In: Leet WS, Dewees CM, Klingbeil R, Larson EJ, editors. California's Living Marine Resources: A Status Report. Sacramento: California Department of Fish and Game; p. 107-111.

Hastings MC, Popper AN. 2005. Effects of sound on fish. Sacramento, CA: California Department of Transportation. CA05-0537.

(HDAR) Hawaii Division of Aquatic Resources. Undated. Bottomfish Restricted Fishing Area E, Makapu'u Point, Oahu. http://hawaii.gov/dlnr/dar/pdf/CoordsE.pdf

Hunt SL, Mulligan TJ, Komori K. 1999. Oceanic feeding habits of Chinook salmon, Oncorhynchus tshawytscha, off northern California. Fishery Bulletin. 97:717-721.

Kalmijn AJ. 1989. Functional evolution of lateral line and inner ear sensory systems. In: Coombs S, Gorner P, Munz H, editors. The Mechanosensory Lateral Line. New York: Springer-Verlag; p. 187-215.

Largier J, Behrens D, Robart M. 2008. The potential impact of WEC development on nearshore and shoreline environments through a reduction in nearshore wave energy. In: Nelson PA, editors. Developing wave energy in coastal California: Potential socio-economic and environmental effects. 
Sacramento, CA: California Energy Commission, PIER Energy-Related Environmental Research Program \& California Ocean Protection Council; p. 57-82.

Leadbitter D, Ward TJ. 2007. An evaluation of systems for the integrated assessment of capture fisheries. Marine Policy. 31(4):458-469.

Littler MM, Littler DS, Blair SM, Norris JN. 1985. Deepest known plant life discovered on an uncharted seamount. Science 227: 57-59.

Lobel PS. 1992. Sounds produced by spawning fishes. Environmental Biology of Fishes. 33:351-358.

Mann DA, Casper BM, Boyle KS, Tricas TC. 2007. On the attraction of larval fishes to reef sounds. Marine Ecology Progress Series. 338:307-310.

Michel J, Dunagan H, Boring C, Healy E, Evans W, Dean JM, McGillis A, Hain J. 2007. Worldwide synthesis and analysis of existing information regarding environmental effects of alternative energy uses on the Outer Continental Shelf. Herndon, VA: U.S. Department of the Interior, Minerals Management Service. MMS 2007-038.

(MMS) Minerals Management Service. 2007. Programmatic environmental impact statement for alternative energy development and production and alternate use of facilities on the Outer Continental Shelf. U.S. Department of the Interior. MMS 2007-046.

Myrberg Jr. AA. 1990. The effects of man-made noise on the behavior of marine animals. Environment International. 16(4-6):575-586.

Nash CE, Burbridge PR, Volkman JK. 2005. Guidelines for ecological risk assessment of marine fish aquaculture. U.S. Department of Commerce, NOAA Technical Memo. NMFS-NWFSC-71.

(NOAA) National Oceanic and Atmospheric Administration. 2007. Wave power: Looking to the ocean for electricity in Oregon [Internet]. U.S. Department of Commerce; [updated March 2007; cited 15 September 2009]. Available from:

http://celebrating200years.noaa.gov/magazine/wave energy/welcome.html\#answer.

(NOAA) National Oceanic and Atmospheric Administration. 2009a. Marine debris: Assessing lost fishing gear and other marine debris in deepwater benthic habitats off California [Internet]. NOAA, Office of Response and Restoration; [updated 4 November 2009; cited 11 November 2009]. Available from: http://marinedebris.noaa.gov/projects/ca benthic.html.

(NOAA) National Oceanic and Atmospheric Administration. 2009b. Marine debris: At-sea detection of lost fishing gear debris in the North Pacific [Internet]. NOAA, Office of Response and Restoration; [updated 4 November 2009; cited 11 November 2009]. Available from:

http://marinedebris.noaa.gov/projects/atsea cruise.html.

(NOAA) National Oceanic and Atmospheric Administration. 2009c. Marine debris: Lost fishing gear in Puget Sound: Prioritizing removal, preventing recruitment, and parameterizing efforts to model biological impacts [Internet]. NOAA, Office of Response and Restoration; [updated 4 November 2009; cited 11 November 2009]. Available from: http://marinedebris.noaa.gov/projects/pgtsound.html. 
Nelson PA, Behrens D, Castle J, Crawford G, Gaddam RN, Hackett SC, Largier J, Lohse DP, Mills KL, Raimondi PT, et al. 2008. Developing wave energy in coastal California: potential socio-economic and environmental effects. California Energy Commission, PIER Energy-Related Environmental Research Program \& California Ocean Protection Council. CEC-500-2008-083.

Norris KS, Evans III EC. 1988. On the evolution of acoustic communication systems in vertebrates, Part I: Historical aspects. In: Nachtigall PE, Moore PWB, editors. Animal Sonar. Plenum Publishing Corporation; p. 655-669.

(OMNR) Ontario Ministry of Natural Resources. 2008. Water resources glossary [Internet]. [updated 10 April 2008; cited 12 November 2009]. Available from: http://www.mnr.gov.on.ca/en/Business/Water/2ColumnSubPage/STEL02 163778.html\#glossL.

(PG\&E) Pacific Gas \& Electric Company. 2007. Application for preliminary permit: PG\&E WaveConnect Project. Washington, DC.

Pauley GB, Armstrong DA, Van Citter R, Thomas GL. 1989. Species profiles: life histories and environmental requirements of coastal fishes and invertebrates (Pacific Southwest)--Dungeness crab. Washington, DC: U.S. Department of the Interior. TR EL-82-4.

Pequegnat JE, Mondeel-Jarvis D, Borgeld JC, Bott L. 1990. Sediment characteristics, benthic infauna, demersal fish and macroinvertebrates: Analysis of community found offshore in water between 18 and 73 meters deep west of Humboldt Bay, California, and at the nearshore disposal site. San Francisco, CA: U.S. Army Corps of Engineers.

Pitcher TJ. 1999. Rapfish, a rapid appraisal technique for fisheries, and its application to the Code of Conduct for Responsible Fisheries. Rome, Italy: Food and Agriculture Organization of the United Nations. 947.

Pitcher TJ, Preikshot D. 2001. Rapfish: A rapid appraisal technique to evaluate the sustainability status of fisheries. Fisheries Research. 49(3):255-270.

Polagye B. 2009a. Hydrodynamic effects of kinetic power extraction by in-stream tidal turbines [dissertation]. University of Washington.

Previsic M. 2009a. Site characterization - Power point presentation. RE Vision consulting, LLC.

Previsic M. 2009b. Working draft - Scenario based analysis of environmental and navigation impacts: Wave power scenario descriptions.

Rogers CS. 1990. Responses of coral reefs and reef organisms to sedimentation. Marine Ecology Progess Series. 62:185-202.

Sara G, Dean JM, D'Amato D, Buscaino G, Oliveri A, Genovese S, Ferro S, Buffa G, Lo Martire M, Mazzola S. 2007. Effect of boat noise on the behaviour of bluefin tuna Thunnus thynnus in the Mediterranean Sea. Marine Ecology Progress Series. 331:243-253.

Schiel DR, Foster MS. 1986. The structure of subtidal algal stands in temperate waters. Oceanography and Marine Biology Annual Review 24:265-307. 
Svane I, Petersen JK. 2001. On the problems of epibioses, fouling and artificial reefs, a review. Marine Ecology. 22(3):169-188.

Tricas TC, Kajiura SM, Kosaki RK. 2006. Acoustic communication in territorial butterflyfish: test of the sound production hypothesis. Journal of Experimental Biology. 209(24):4994-5004.

(USN) U.S. Department of the Navy. 2005. Marine Resources Assessment for the Hawaiian Islands Operating Area. Pacific Division, Naval Facilities Engineering Command, Pearl Harbor, HI: Department of the Navy, Commander, U.S. Pacific Fleet. Contract \# N62470-02-D-9997, CTO 0026.

Wilson JH, Beyene A. 2007. California wave energy resource evaluation. Journal of Coastal Research. 23(3):679-690. 